OECD Economics Department Working Papers No. 1000

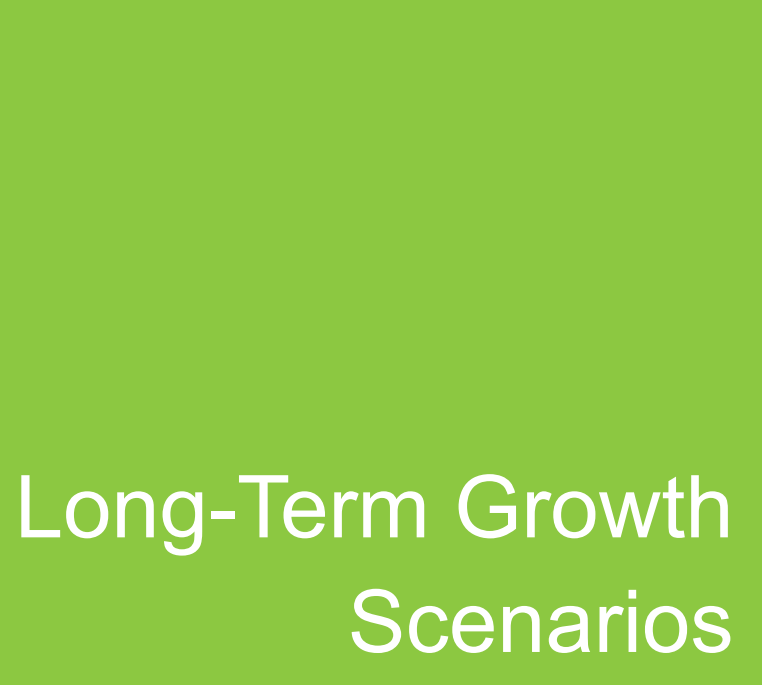

\author{
Asa Johansson, \\ Yvan Guillemette, \\ Fabrice Murtin, \\ David Turner,
} Giuseppe Nicoletti, Christine de la Maisonneuve, Philip Bagnoli, Guillaume Bousquet, Francesca Spinelli 
Organisation de Coopération et de Développement Économiques

Organisation for Economic Co-operation and Development

28-Jan-2013

ECONOMICS DEPARTMENT

English - Or. English

\section{LONG-TERM GROWTH SCENARIOS}

ECONOMICS DEPARTMENT WORKING PAPERS No.1000

By Åsa Johansson, Yvan Guillemette, Fabrice Murtin, David Turner, Giuseppe Nicoletti, Christine de la Maisonneuve, Phillip Bagnoli, Guillaume Bousquet and Francesca Spinelli

All Economics Department Working Papers are available through OECD's internet web site at http://www.oecd.org/eco/workingpapers

Complete document available on OLIS in its original format

This document and any map included herein are without prejudice to the status of or sovereignty over any territory, to the delimitation of international frontiers and boundaries and to the name of any territory, city or area. 


\section{ABSTRACT/RÉSUMÉ}

\section{Long-term growth scenarios}

This paper presents the results from a new model for projecting growth of OECD and major non-OECD economies over the next 50 years as well as imbalances that arise. A baseline scenario assuming gradual structural reform and fiscal consolidation to stabilise government-debt-to GDP ratios is compared with variant scenarios assuming deeper policy reforms. One main finding is that growth of the non-OECD G20 countries will continue to outpace OECD countries, but the difference will narrow substantially over coming decades. In parallel, the next 50 years will see major changes in the composition of the world economy. In the absence of ambitious policy changes, global imbalances will emerge which could undermine growth. However, ambitious fiscal consolidation efforts and deep structural reforms can both raise long-run living standards and reduce the risks of major disruptions to growth by mitigating global imbalances.

JEL classification codes: O47; O43; O11; J11; I25; H68; F43; E27.

Key words: Growth; conditional convergence; long-run projections; human capital; productivity; savings; current accounts; fiscal and structural policy; global imbalances.

$* * * * * * *$

\section{Scénarios de croissance à long terme}

Cette étude présente les résultats d'un nouveau modèle de projection de la croissance économique des pays de l'OCDE et des pays majeurs hors-OCDE sur un horizon de 50 ans ainsi que des déséquilibres qui apparaissent. Un scénario de référence, qui comprend des réformes structurelles graduelles et un assainissement budgétaire suffisant pour stabiliser les ratios de dette/PIB, est comparé à des scénarios alternatifs qui incluent des réformes plus profondes des politiques publiques. Une des conclusions principales est que la croissance des pays du G20 non membres de l'OCDE continuera de dépasser celle des pays membres, mais la différence s'amenuisera au cours des prochaines décennies. Parallèlement, les 50 prochaines années verront des changements majeurs dans la composition de l'économie mondiale. En absence de refonte ambitieuse des politiques publiques, des déséquilibres mondiaux dangereux pour la croissance émergeront. Cependant, une rationalisation plus prononcée des finances publiques combinée à des réformes structurelles profondes pourrait à la fois faire augmenter les niveaux de vie et réduire les risques de déraillement majeur de la croissance en réduisant les déséquilibres mondiaux.

Classification JEL: 047 ; 043 ; O11 ; J11 ; 125 ; H68 ; F43 ; E27.

Mots clefs : Croissance ; convergence conditionnelle ; projections à long terme ; capital humain ; productivité ; épargne ; comptes courants ; politiques fiscales et structurelles ; déséquilibres mondiaux. 


\section{TABLE OF CONTENTS}

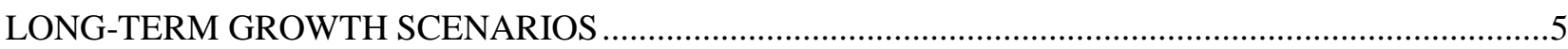

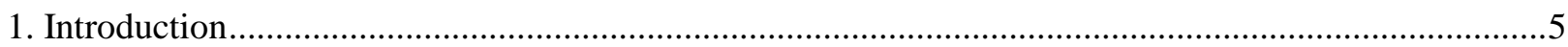

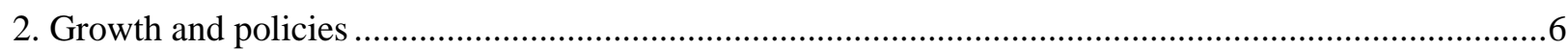

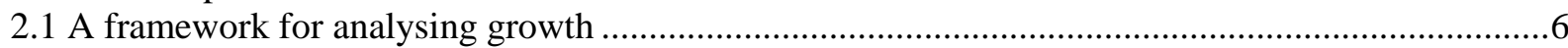

2.2 Structural and fiscal policies play a key role in shaping the macro outlook …................................

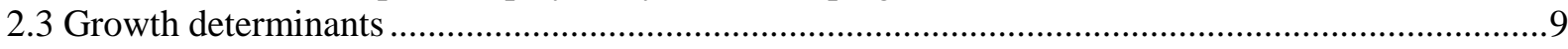

3. A globally consistent long-term macroeconomic baseline ..............................................................25

3.1. GDP per capita gaps will shrink but significant cross-country differences will persist .................27

3.2 The relative size of economies will change dramatically ................................................................

3.3 Macroeconomic imbalances will build up without strong policy actions ........................................33

4. Bold macro and structural policies can enhance growth and reduce global imbalances ......................41

4.1 Ambitious fiscal policies can reduce indebtedness and global imbalances......................................41

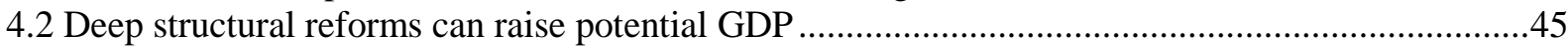

4.3 Ambitious fiscal consolidation and structural reforms can reduce imbalances and boost growth...47

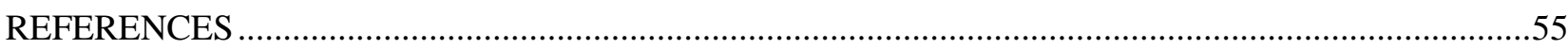

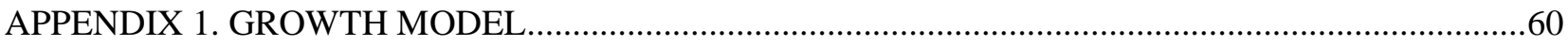

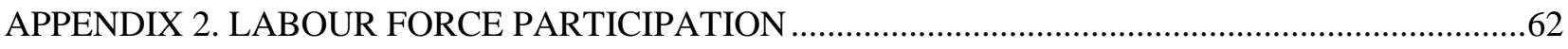

APPENDIX 3. DEFINITION AND CALCULATION OF ACTIVE LIFE EXPECTANCY .....................64

APPENDIX 4. PROMOTING LABOUR FORCE PARTICIPATION ..................................................65

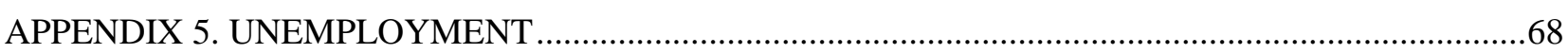

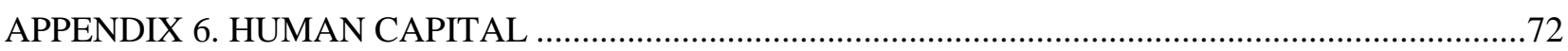

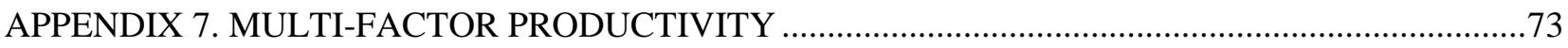

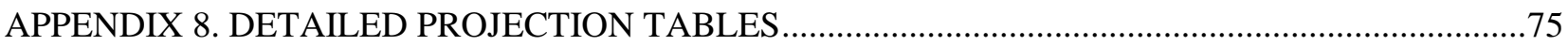

APPENDIX 9. CONVERGENCE IN HOURS WORKED HAS LITTLE IMPACT ON PROJECTIONS .78 APPENDIX 10: TECHNICAL DESCRIPTION OF THE BASELINE LONG-TERM (BLT) MODEL.....79

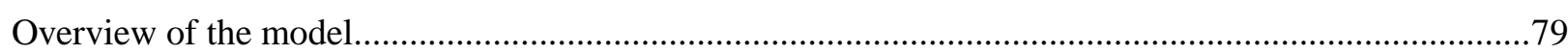

\section{Boxes}

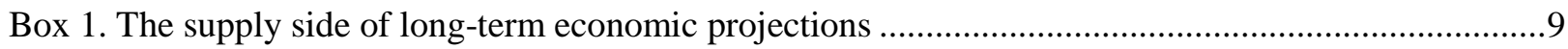

Box 2. The cohort approach to project labour force participation ...........................................................16

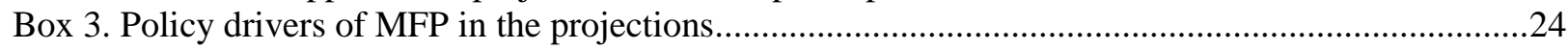

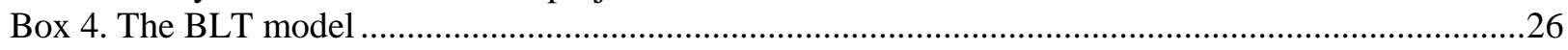

Box 5. Market exchange rates versus Purchasing Power Parities........................................................28

Box 6. Assumptions underlying the baseline projections of growth, savings and investment ..................33

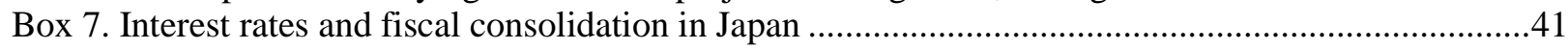


ECO/WKP(2012)77 
ECO/WKP(2012)77

\title{
LONG-TERM GROWTH SCENARIOS
}

\author{
By Åsa Johansson, Yvan Guillemette, Fabrice Murtin, David Turner, Giuseppe Nicoletti, Christine de \\ la Maisonneuve, Phillip Bagnoli, Guillaume Bousquet and Francesca Spinelli ${ }^{1}$
}

\section{Introduction}

1. This paper describes long-term growth scenarios for the world economy based on a new modelling framework. The new framework sketches the possible transition from the current conjuncture to growth developments in OECD and non-OECD G20 countries up to 2060 focusing on the interaction between technological progress, demographic change, fiscal adjustment, global imbalances and structural policies. It is consistent with the framework used for short-term projections in the Economic Outlook, and will provide the basis for the estimation of potential output and output gaps. ${ }^{2}$ The main findings emerging from the analysis are:

- Facilitated by continued fiscal and structural reforms and sustained by the rising share of relatively fast-growing emerging countries in global output, global GDP could grow at around 3\% over the next 50 years.

- Growth of the non-OECD will continue to outpace the OECD, but the difference will narrow substantially over coming decades. From over $7 \%$ per year over the last decade, non-OECD growth will decline to around 5\% in the 2020s and to about half that by the 2050s. Until 2020, China will have the highest growth rate, but will be then surpassed by both India and Indonesia.

- Once the legacy of the global financial crisis has been overcome, trend growth for the OECD will recover to average $1 \frac{3 / 4}{4}$ to $2^{1 / 4}$ per cent per annum.

- The next 50 years will see major changes in the composition of the world economy. Fast growth in China and India will make their combined GDP, measured at 2005 Purchasing Power Parities (PPPs), go from adding up to less than half of the total output of the major seven OECD economies

The authors are all at the OECD Economics Department. Corresponding authors are:

Åsa Johansson (Asa.Johansson@oecd.org) and David Turner (David.Turner@oecd.org)

The authors would like to thank Jørgen Elmeskov and Jean-Luc Schneider for their valuable comments, Irene Sinha for excellent editorial support and Sylvie Toly for excellent statistical help. The paper has also benefited from comments by members of Working Party No. 1 of the OECD Economic Policy Committee and seminar participants at the OECD Economics Department. The views expressed in this paper are those of the authors and do not necessarily reflect those of the OECD or its member countries.

2. This new modelling framework will also replace the existing model for producing the medium-term baseline (MTB) that provides both an anchor and an extension to the OECD short-run projections. For details on the previous version of the MTB model, see Beffy et al. (2006). 
in 2010 to exceeding it around 2025. Strikingly, their combined GDP will exceed that of the entire current OECD membership by 2060.

- Large GDP per capita differences will nonetheless persist in 2060. Income per capita in the poorest economies will more than quadruple by 2060 , and China and India will experience more than a seven-fold increase, but living standards in these these countries and some other emerging countries will still only be one-quarter to $60 \%$ of the level of the leading countries in 2060 .

- In the absence of more ambitious policy changes, rising imbalances could undermine growth. As the current cycle unwinds, the scale of global current account imbalances may increase and return to pre-crisis peaks by 2030 . Government indebtedness among many OECD countries will exceed thresholds at which there is evidence of adverse effects on interest rates and growth. Global interest rates may therefore start to rise over the long-term.

- More ambitious long-term fiscal consolidation among OECD countries can help: by reducing country-specific fiscal risk premia; by helping to relieve global current account imbalances; and by boosting global savings and hence reducing upward pressures on global interest rates. Lowering government indebtedness would also reduce vulnerability to any future decline in global saving rates, whether due to ageing or other factors.

- Deep structural policy reforms could raise long-run living standards by about $16 \%$ on average across countries relative to a scenario of milder policy improvements. Ambitious product market reforms, which are found to play a role in the convergence of technical progress, could increase standards of living by an average of about $10 \%$. Moreover, policies that induce convergence towards best-practice labour force participation could raise living standards by close to $6 \%$ on average, with much larger effects in some countries.

- Together, ambitious fiscal consolidation efforts and deep structural reforms can both raise long-run living standards and reduce the risks of major disruptions to growth by mitigating global imbalances, raising aggregate OECD GDP by $11 \%$ and non-OECD GDP by $17 \%$, with much larger effects in countries where structural policy settings lag most behind best practice.

2. The remainder of the paper is organised as follows. Section 2 introduces the new framework and discusses future developments in the main supply-side drivers of economic growth -- including multifactor productivity, human and physical capital and labour -- assuming that policies in labour and product markets gradually converge according to a moderate structural reform agenda. Section 3 combines all these drivers to generate a baseline scenario for long-term growth in individual countries, and highlights the implications of the long-term growth scenario for investment, saving and current accounts, assuming that fiscal policies stabilise public debt ratios. Finally, section 4 assesses the impact of much bolder structural and macroeconomic policy reforms on future economic growth and global imbalances.

\section{Growth and policies}

\subsection{A framework for analysing growth}

3. While there is no single theory of economic growth, there is wide support for an analytical framework in which each country converges to its own steady-state trajectory of GDP per capita determined by the interface between global technological progress and country-specific structural conditions and policies (so-called conditional convergence). In the long run, all countries grow at the same rate, determined by the worldwide rate of technical progress, but cross-country GDP per capita gaps remain, mainly reflecting differences in technology levels, capital intensity, human capital and population. 
These in turn partly depend on differences in structural conditions and policies. In this framework, two forces can act to reduce cross-country GDP per capita gaps in the long run: first, countries that are initially below their steady state level of GDP per capita "catch-up" to this level, principally as a result of accumulation of different kinds of capital (human and physical) and improvements in efficiency driven by technology adoption and innovation; second, cross-country differences in steady-state GDP per capita are evened out as some structural conditions converge (e.g. due to globalisation) and best policy practices spread out, affecting in turn factor accumulation, efficiency improvements and the speed of catch up.

4. Within this framework, the projections in this study account for cross-country differences in labour utilisation, human and physical capital intensity, multi-factor productivity (a proxy for technology) and policies in labour and product markets, including trade barriers. Accordingly, long-term growth projections are based on future scenarios for each of these components, with labour utilisation being further decomposed into developments in the underlying demographics (e.g. working-age population), labour force participation and unemployment (Box 1). ${ }^{3}$ Demographic trends, including ageing, shape the future path of labour and human capital and, in turn, GDP per capita developments.

5. Historically, growth has been driven mainly by developments in multifactor productivity (MFP) and human and physical capital intensity (so-called capital deepening). But, with decreasing marginal returns to capital, capital deepening itself can only be sustained by continuous technological progress, as subsumed in MFP growth. In keeping with this, the framework used in this study assumes that:

- Over the long term, sustained MFP growth through technological improvements is crucial for GDP per capita developments. In each country, MFP growth is driven by the global rate of technical progress and by the speed at which lagging economies embody new technology and improve efficiency in order to catch up to the level of technology that is consistent with their own structural conditions and policies. Therefore, differences in MFP are the main factor driving differences in GDP per capita across countries.

- The underlying ratio of capital-to-potential-output is projected to be relatively stable, or, if this is contradicted by recent history, it is assumed to gradually stabilise. In addition, the underlying capital-output ratio is assumed to be sensitive to the cost of capital, which in turns means that there is an influence from tensions arising in financial markets (see below). ${ }^{4}$

- Another driver of growth is human capital accumulation. The projections take into account the influence of human capital on labour productivity through the accumulation of education over time (Mankiw, Romer and Weil, 1992). ${ }^{5}$

3. Sensitivity analysis suggests that the long-term projections are not qualitatively affected by accounting for differences and projected evolutions in hours worked (see Appendix 9).

4. Conversely, for simplicity, there is no explicit feedback from structural policies to the rate of capital formation, such as would be suggested by Alesina et al. (2005) and Égert (2009). However, implicitly, policies that raise GDP also raise capital so as to maintain, ceteris paribus, the capital-output ratio unchanged over time.

5. Measures of the quality of education have been proposed by the OECD derived from the PISA surveys and were found to be highly correlated with per capita GDP growth (Hanushek and Woessmann, 2010). However, it is difficult to assess the direction of causality between quality of education and economic performance. For this reason, the quantity of education is the main dimension explored in this project. Projections also do not account for the increased capacity of the workforce to innovate or adopt existing foreign technologies as the average level of education is improving (Nelson and Phelps, 1996; Griffith et al., 2004; Aghion and Howitt, 2009). 
- The framework adopted here does not explicitly build in any permanent effect of the crisis on potential growth rates, although the crisis is estimated to have had a permanent adverse effect on the level of potential output. Compared to pre-crisis projections, the level of aggregate OECD potential output, both currently and over the next few years, has been revised downwards by 2 to $2 \frac{1}{2}$ per cent. $^{6}$

\subsection{Structural and fiscal policies play a key role in shaping the macro outlook}

6. Structural and fiscal policies play an important role in shaping the long-run projections for growth and fiscal and global imbalances in this study. The framework takes into account a number of policy links, including the impact of labour market policies on developments in unemployment and labour force participation, the impact of product market and trade regulations on innovation and technological diffusion as well as the impact of fiscal consolidation and enhanced welfare policies in emerging economies on global imbalances, indebtedness and capital accumulation via changes in the cost of capital.

7. Over a time horizon covering several decades, these structural conditions and policies are likely to adapt to economic circumstances. As a consequence, drawing long-run scenarios at unchanged policies may result in unsustainable growth projections. Therefore, the baseline long-run scenario incorporates a number of policy assumptions in several areas: ${ }^{7}$

- Effective old-age retirement evolves in line with life expectancy, so as to maintain the average share of lifetime spent in activity unchanged over the projection period; and recently-legislated pension reforms that involve an increase in the normal retirement age by 2020 are implemented as planned;

- Educational attainment continues to converge across countries, relying implicitly on an expansion of education systems, particularly in countries with currently low educational attainment levels, and this increases in attainment also influences projected labour force;

- In countries where product market and trade regulations are initially more restrictive than in the average OECD country, they gradually converge towards the average regulatory stance observed in the OECD in $2011 ;^{8}$

- Sufficient budget consolidation in OECD countries is undertaken to stabilise government-debt-toGDP ratios, albeit in many cases at high levels;

- Public spending on health care and social benefits rises in non-OECD economies, but only very gradually over the next three decades; and

6. Studies of the effect of past financial crises on GDP tend to find considerable heterogeneity in responses across different countries, with an important factor being how policy responds to the crisis, see for example, Haugh et al. (2009).

7. Baseline projections for European Programme countries (e.g. Greece) do not take into account the impact of structural reforms announced in the recent programmes, which could alter growth prospects and fiscal positions for these countries.

8. Regulations are assumed to remain unchanged in countries where they are already less restrictive than (or at) the OECD average. 
- Credit availability gradually increases as a function of financial deepening over the coming decades, faster in countries where it is initially lower than where it is currently deepest (United States).

8. While the baseline scenario already incorporates policy change, there is considerable scope for further fiscal consolidation and deeper structural reforms to improve living standards and reduce the buildup of macroeconomic imbalances, as explored in two variant scenarios. More specifically, the first scenario considers the implications for global imbalances and growth of stronger fiscal consolidation in high debt countries. The second scenario builds on the first scenario with much deeper structural reforms, in order to further reduce the risks of major disruptions to growth by mitigating global imbalances while boosting GDP through growth-friendly policies.

\section{Box 1. The supply side of long-term economic projections}

The supply side of the economy consists of a standard aggregate Cobb-Douglas production function with constant returns to scale featuring physical capital, human capital and labour as production factors plus technological progress (so-called multi-factor productivity). Multi-factor productivity is measured as the difference between output and total inputs (see Appendix 1 for details).

These components of the production function are projected to 2060 in order to construct measures of potential GDP measured in terms of constant 2005 USD purchasing power parities (PPPs) (see Easterly and Levine, 2001; OECD, 2003; Duval and de la Maisonneuve, 2010 and Fouré et al., 2010 for similar approaches). The projections for all components to 2013 are consistent with the May 2012 OECD Economic Outlook projections, although some elements of the short-term non-OECD projections are taken from IMF (2012). An exception is the projection of human capital which starts in 2011 as there is no short-term forecast available. Further details of the methodology used to make the long-term projections, including the parameterisation of the links between structural factors and the components of GDP, including via new regression estimates are provided in Appendices 2 to 7.

It should be kept in mind that projections made over several decades are inherently speculative, with many layers of uncertainty including the determinants of growth and the size of their impact on growth.

\subsection{Growth determinants}

9. Historically, cross-country gaps in multi-factor productivity and, to a lesser extent, in human capital have accounted for the bulk of cross-country differences in GDP per capita (e.g. Easterly and Levine, 2001; Duval and de la Maisonneuve, 2010). As shown in Figure 1A, differences in MFP relative to the United States are particularly sizeable in Eastern European countries, Latin American countries and in emerging economies (e.g. China, India, Brazil, Indonesia and the Russian Federation). Large gaps in productivity also characterise a few higher-income economies, such as Japan, Korea and Switzerland.

10. Gradual closure of these gaps has also accounted for the greater part of GDP per capita growth over the past decade (Figure 1B) and, given the remaining gaps, MFP is likely to be a crucial driver of long-run GDP per capita convergence in the future. Additionally, considerable scope for improvements in educational attainment exists in several countries -- e.g. Portugal, Turkey, South Africa, China, India and Indonesia. While in the past decade labour has accounted for an important part of GDP per capita growth -on average 0.5 percentage points -- going forward, most countries will have ageing populations with adverse implications for labour force participation and growth.

11. Starting from this historical decomposition of GDP per capita, long-run projections are generated for each of the identified components of GDP for OECD as well as for non-OECD G20 countries. Furthermore, for the purposes of identifying pressures on global current account balances, a group of major 
non-OECD oil exporting countries is also defined, which includes Saudi Arabia and Russia as well as 23 smaller countries.

12. In the remainder of this section, projections for the GDP components are explained starting with labour utilisation and human capital, which hinge on relatively well-established trends, and ending with capital intensity and MFP, for which future trends are more speculative. The influence of different policy assumptions on the projected evolution of these components is also explored.

\section{Figure 1. Scope for catch-up in productivity and human capital in many countries}

A: Contribution of production factors to trend GDP per capita gap relative to the US at constant USD 2005 PPPs, $2011^{1}$

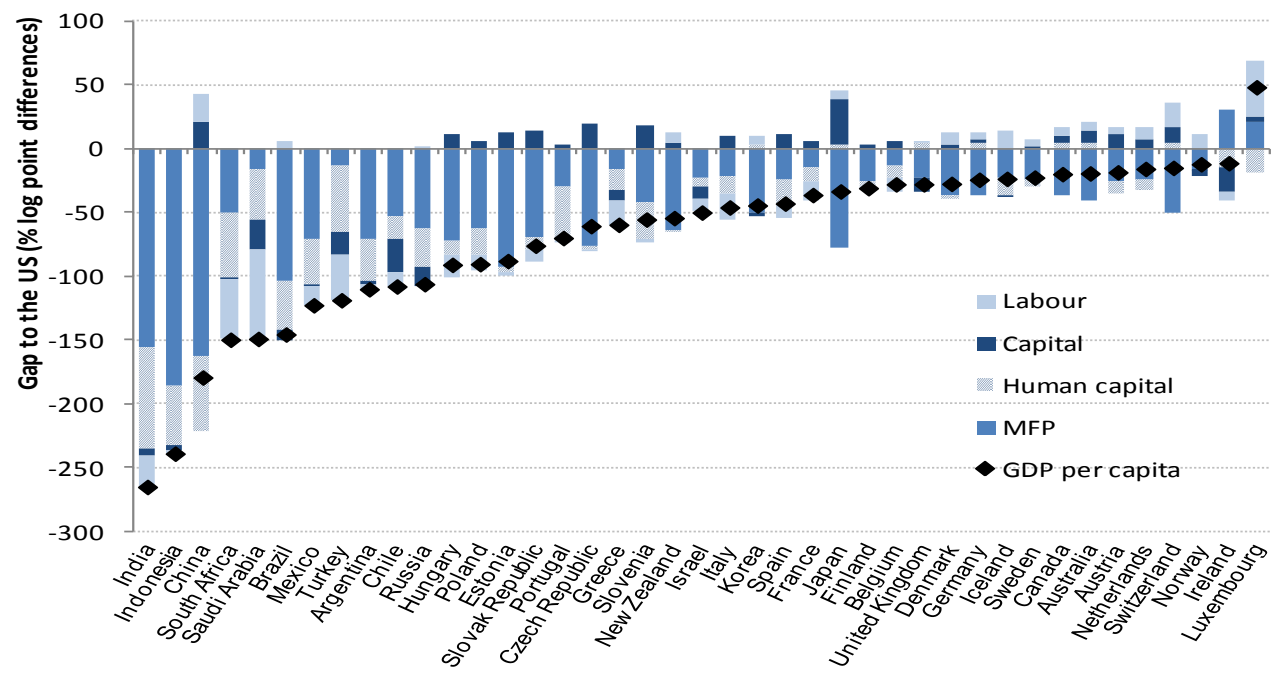

B: Contribution of drivers of growth to annual average trend GDP per capita growth 2000-2011

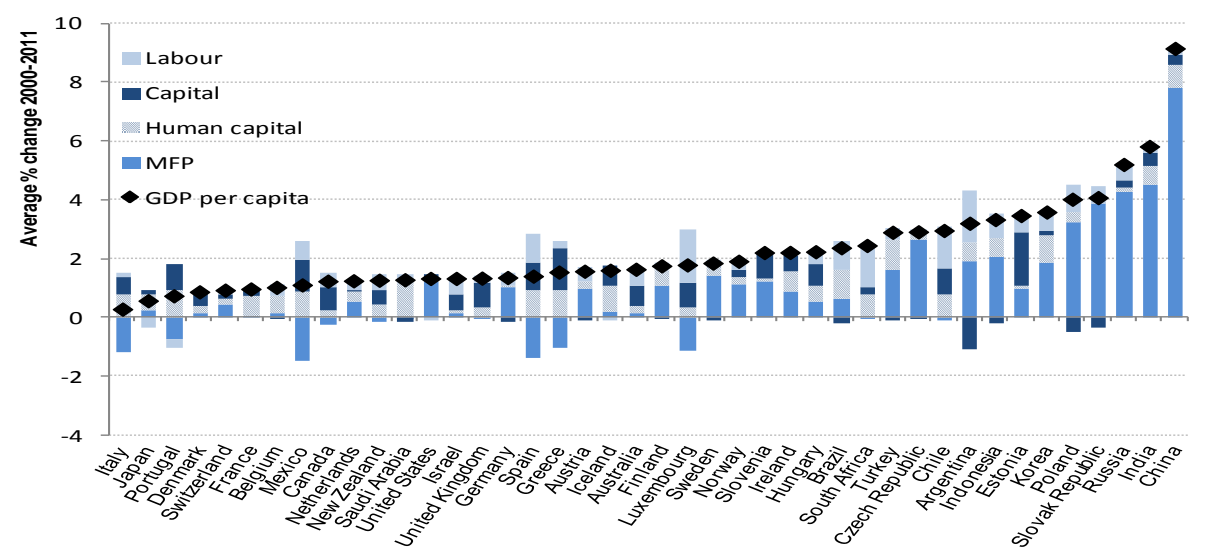

1. To ensure that the percentage gap in the components of GDP add up to GDP per capita, the decomposition is done in log point differences since the decomposition is multiplicative. GDP per capita is equal to the product of the components MFP, human capital, (physical capital/GDP) ${ }^{\alpha /(1-\alpha)}$ and employment/population.

9. Treatment of non-OECD G20 countries, as well as Mexico, Turkey and Chile, is somewhat less detailed as compared to the OECD countries due to insufficient data coverage in some areas. For the 23 smaller countries, no separate projections of current balances are made. Rather, the combined current account balance of all non-OECD oil exporting countries is projected based on projections of their balance of trade in oil. 


\subsubsection{Population ageing will reduce the share of the working-age population in most countries}

13. Two key features shaping demographic trends are developments in fertility and longevity. In many high-income countries, fertility rates dropped below the replacement threshold of 2.1 children per woman in the 1970s, and reached very low levels in the 1990s before eventually picking up slightly. In 2010 , fertility rates in the countries included in this paper stood on average at 1.8 children per woman, with particularly low rates in some Southern and Eastern European countries, Korea and Japan, while being much higher (typically above 2.5 ) in emerging countries. At the same time, in higher-income countries, life expectancy has risen at a steady pace with an increase of about two years per decade since the 1960s (OECD, 2011a), which is largely explained by the increase in life expectancy at older age. ${ }^{10}$ Nevertheless, mainly due to differences in improvements of health standards, life expectancy at birth spans a wide range across countries, with Japan having the longest ( 83 years) and South Africa the shortest ( 52 years).

14. As gains in longevity are not everywhere sufficient to offset the consequence of fertility rates remaining well below replacement levels for an extended period of time, total population is projected to decline by more than $10 \%$ in Germany, Japan, the Russian Federation, Poland, Estonia and Hungary over the projection period 2011-2060 (United Nations and Eurostat Population projections, see Appendix 1). By contrast, population is projected to increase by more than $40 \%$ in countries with relatively high fertility rates, such as Saudi Arabia, Israel, India or Ireland. Overall, total population among the 42 countries included in this study is projected to increase by around $14 \%$ (from 4.5 to 5.2 billion).

15. Mainly as a result of gains in longevity, the population has been ageing in most countries, although at differing speeds. High-income and emerging countries currently display different age structures as a result of the delayed timing of the global demographic transition that started in many developing economies only in the second half of the $20^{\text {th }}$ century. ${ }^{11}$ For instance, the share of the population aged over 60 is much smaller in China than in Japan (Figure 2). More generally, population ageing is already apparent in several high-income countries (e.g. Japan, Germany and Italy) with traditionally-defined oldage dependency ratios -- population aged over 65 divided by population aged between 15 and 64 -standing at 30\% or above (Figure 3A) compared to around 5\% in Saudi Arabia or 17\% in the Russian Federation, which is more typical of emerging countries.

16. Population projections suggest that these trends are likely to continue, resulting in more than a doubling of old-age dependency ratios by 2060 in a majority of countries. ${ }^{12}$ This trend is particularly pronounced in Saudi Arabia, China, Korea, Brazil, Turkey and Indonesia as these countries experience more than a quadrupling in old-age dependency ratios by 2060. In parallel, the share of the working-age population is projected to decline in most countries over the period 2011 to 2060 -- by on average about 9 percentage points (Figure 3B). Some emerging economies differ from high-income countries in this respect: South Africa and India will experience an increase in their share of working-age population. This

10. For instance, life expectancy at birth has increased by nearly 11 years in France between 1960 and 2008 , while life expectancy at age 65 has increased by just over 6 years over the same period. Over a longer time horizon, growth in life expectancy has been even faster -- since 1870 it gained nearly three years per decade among high-income countries (Bourguignon and Morrisson, 2002). This faster pace is largely explained by the dramatic decline in child mortality over the period.

11. Whereas the decline in fertility was initiated among high-income countries during the second half of the $19^{\text {th }}$ century, it started later -- in the 1920 s -- in Eastern European and some Latin American countries, and only in the 1960s in many developing and emerging countries (Chesnais, 1986; Murtin, 2012). Adult and infant mortality also varied widely across countries over the contemporary period, as for instance infant mortality was equal to 10 deaths per 1000 in France in 1980 compared to 100 deaths in India in the same year.

12. The increase in the old-age dependency ratio may be overly pessimistic as it is possible that gains in longevity could result in longer active working-lives, either policy induced or voluntary. 
effect is the well-known "demographic dividend" of the recent decline in fertility rates in those countries, which lowers the youth dependency ratio after one generation (Bloom et al., 2003).

Figure 2. Population age pyramids: China and Japan

Share of age groups in total population, per cent

China

2010

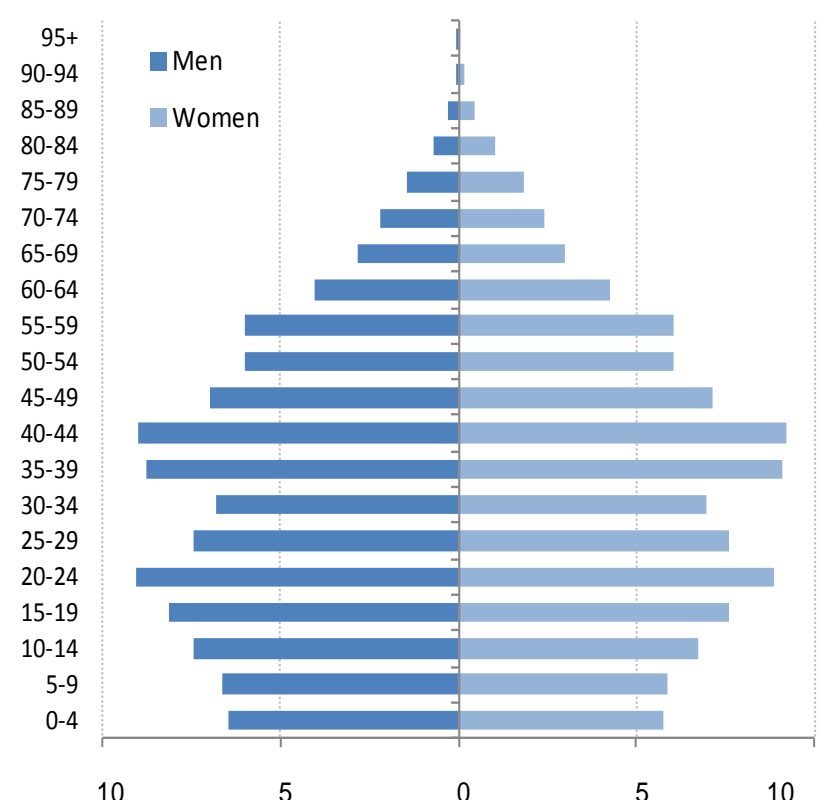

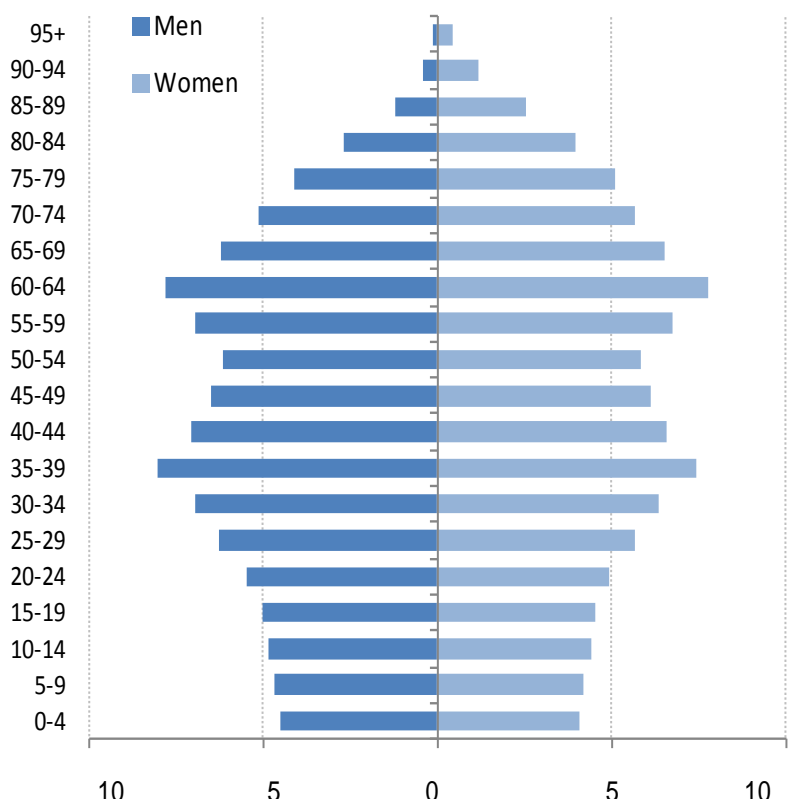

Source: United Nations and Eurostat.

Japan

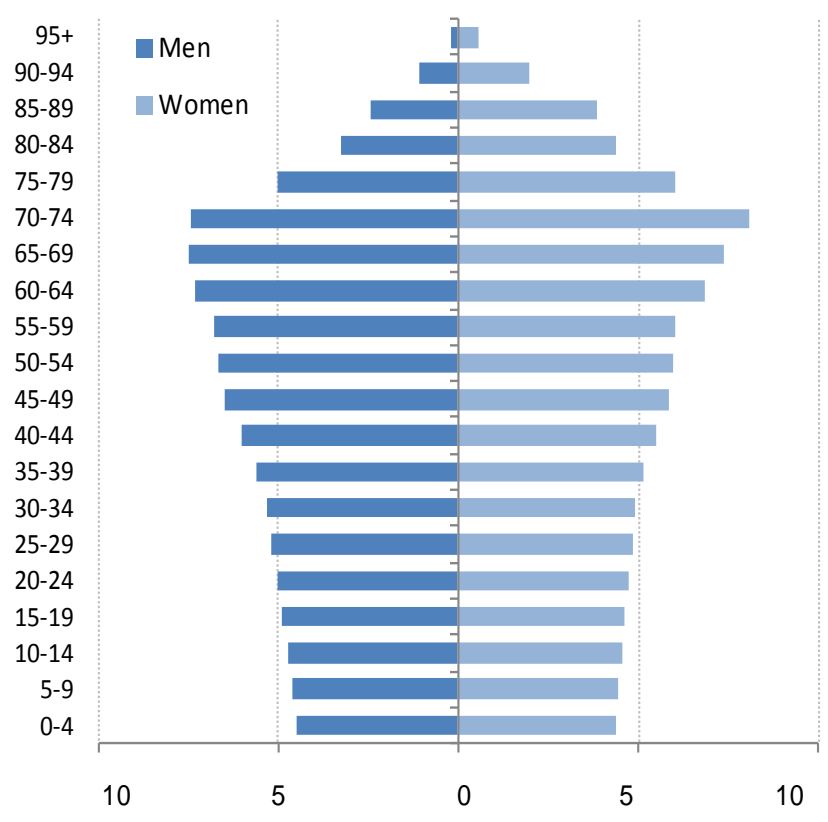

2060

2060

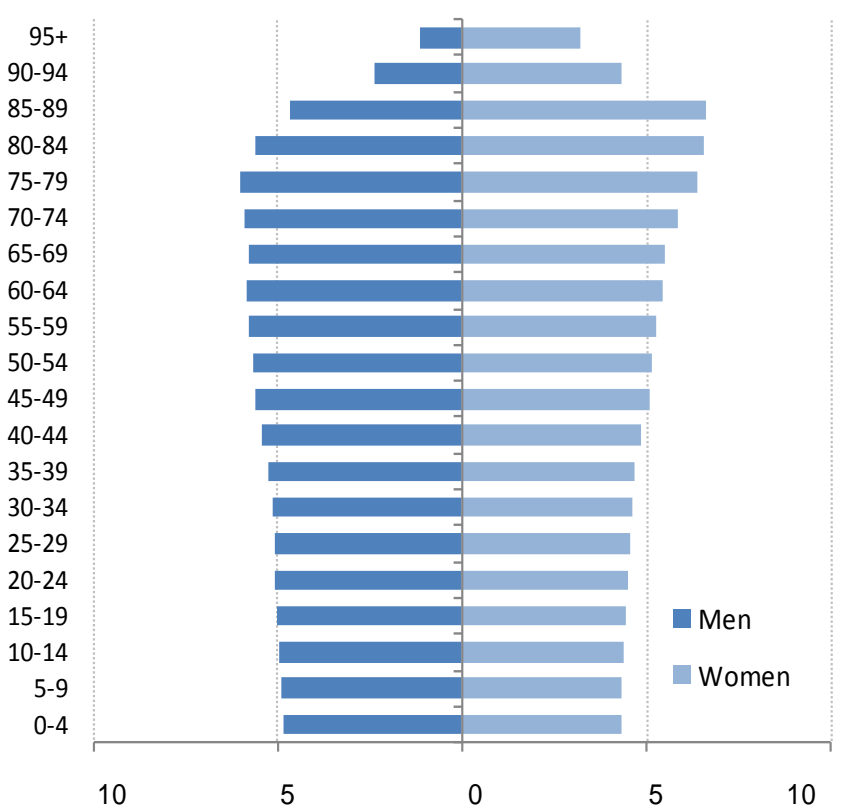


Figure 3. Populations will age in most countries

A: The traditionally-defined old-age dependency ratio steadily rises

Per cent of the population older than 65 as a share of population aged 15-64.

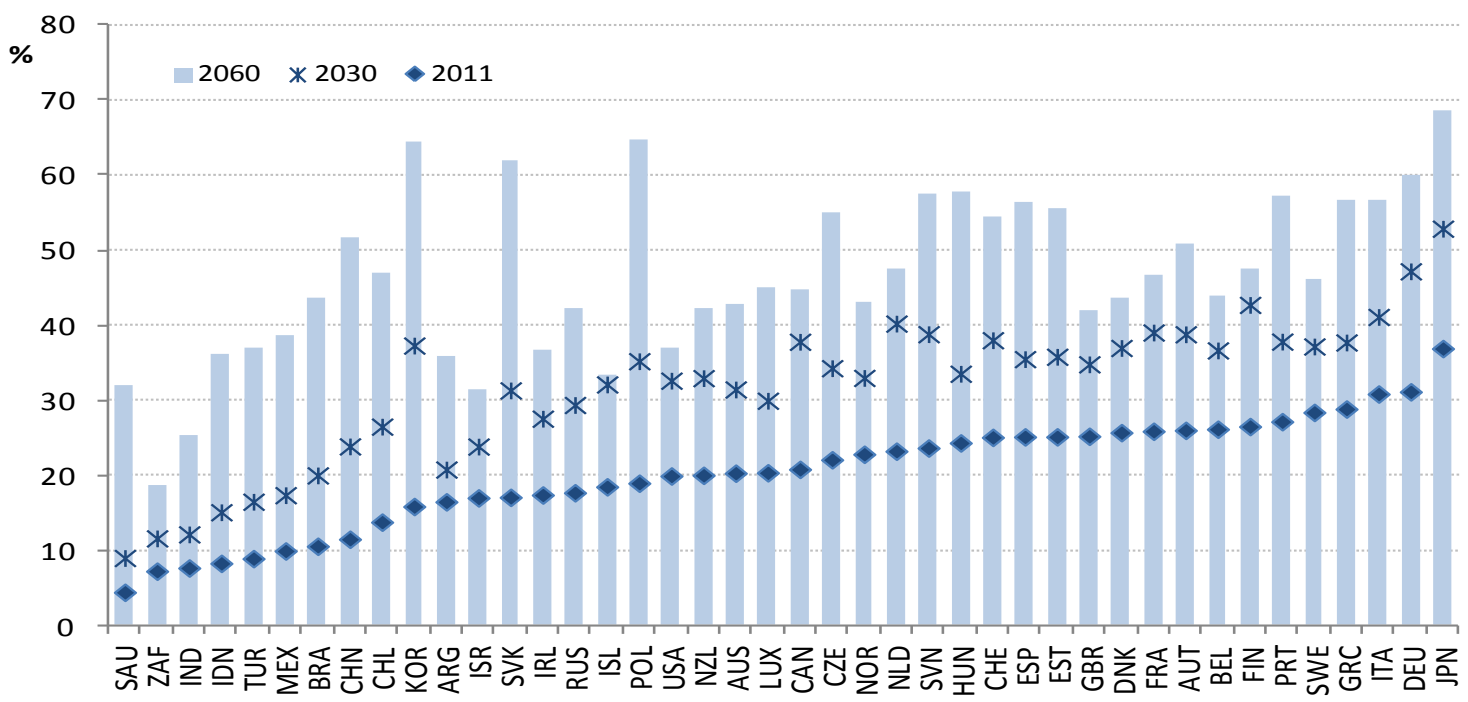

B: The population of traditional working age steadily declines

Share of the population aged 15-64 in total population

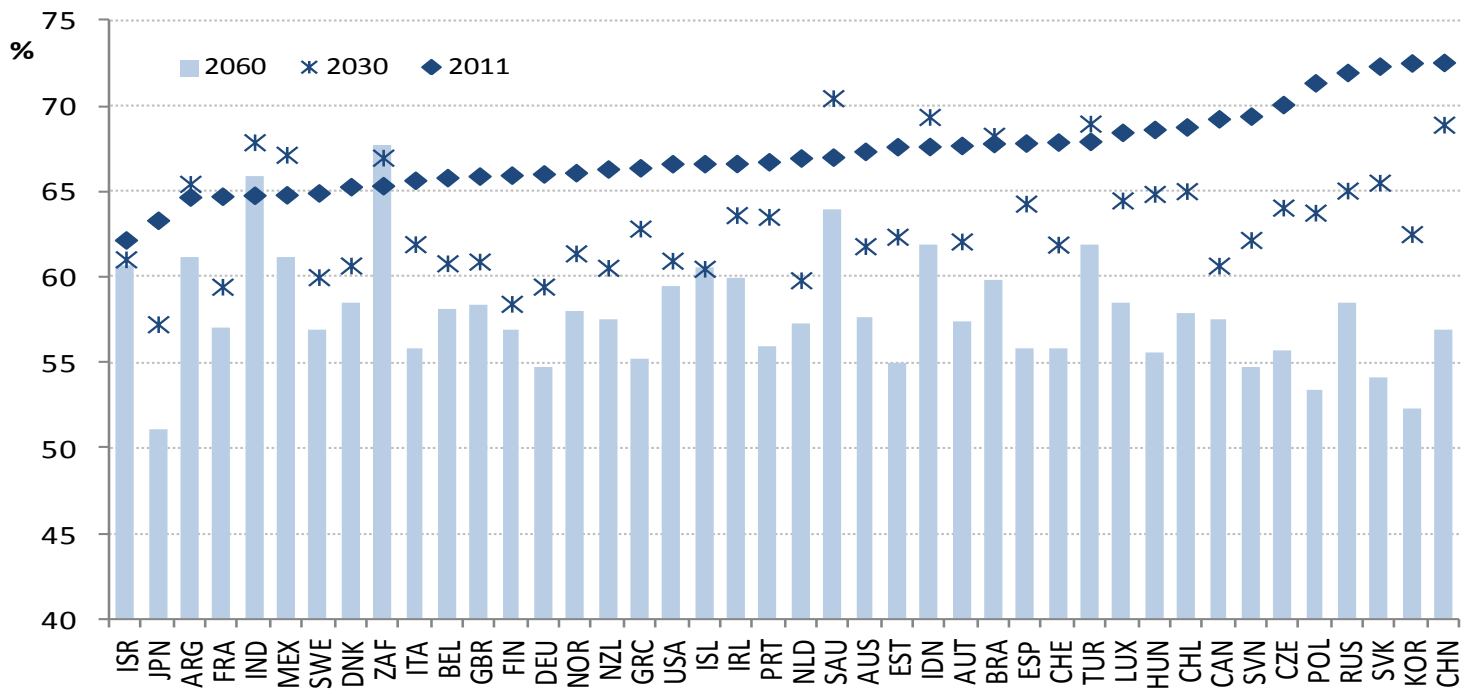

Source: United Nations and Eurostat.

17. In the long run, net migration could have a substantial impact on population growth and the working-age population if migration flows remain sufficiently large and sustained over time. In 2009, foreign-born individuals accounted for more than $10 \%$ of the total population in a majority of OECD countries, and since 2000 the share of immigrants in the population has increased, on average by $2^{1 / 2}$ percentage points, with particularly strong growth in Ireland, Spain and Austria (OECD, 2011b). By contrast, emigration flows have been large in Mexico with an impact on demographic trends: population growth was about $1 \frac{1}{2}$ per cent in 2008 , but when accounting for emigration it was only about half that (Zuniga and Molina, 2008). 
18. If past trends continue, the positive contribution of net migration is projected to either mitigate the decline in population in some European countries or even offset the reduction in native population, notably in Austria, Italy, Spain and Switzerland (Figure 4A). ${ }^{13}$ Moreover, because the foreign-born population has been disproportionately composed of working-age adults, migration has in the past lowered the dependency ratio. This effect was particularly marked in high-immigration countries such as Luxembourg, Spain or Germany, whereas the opposite occurred in high-emigration countries such as Estonia or Poland. If the age composition of immigrants were to remain the same in the future, the projected increase in dependency ratios would also be mitigated in some countries (Figure 4B). Even so, given the sheer size of the projected average increase in this rate (26 percentage points by 2060) and reasonable assumptions on labour force participation rates of migrants, policies aiming at attracting net migration would be unable to offset the adverse consequences of population ageing on the labour force (see Appendix 4).

Figure 4. Migration is expected to have a large impact on population growth: selected countries ${ }^{1}$

A. Change in total population $2010-2060$ (in \% of 2010 population)

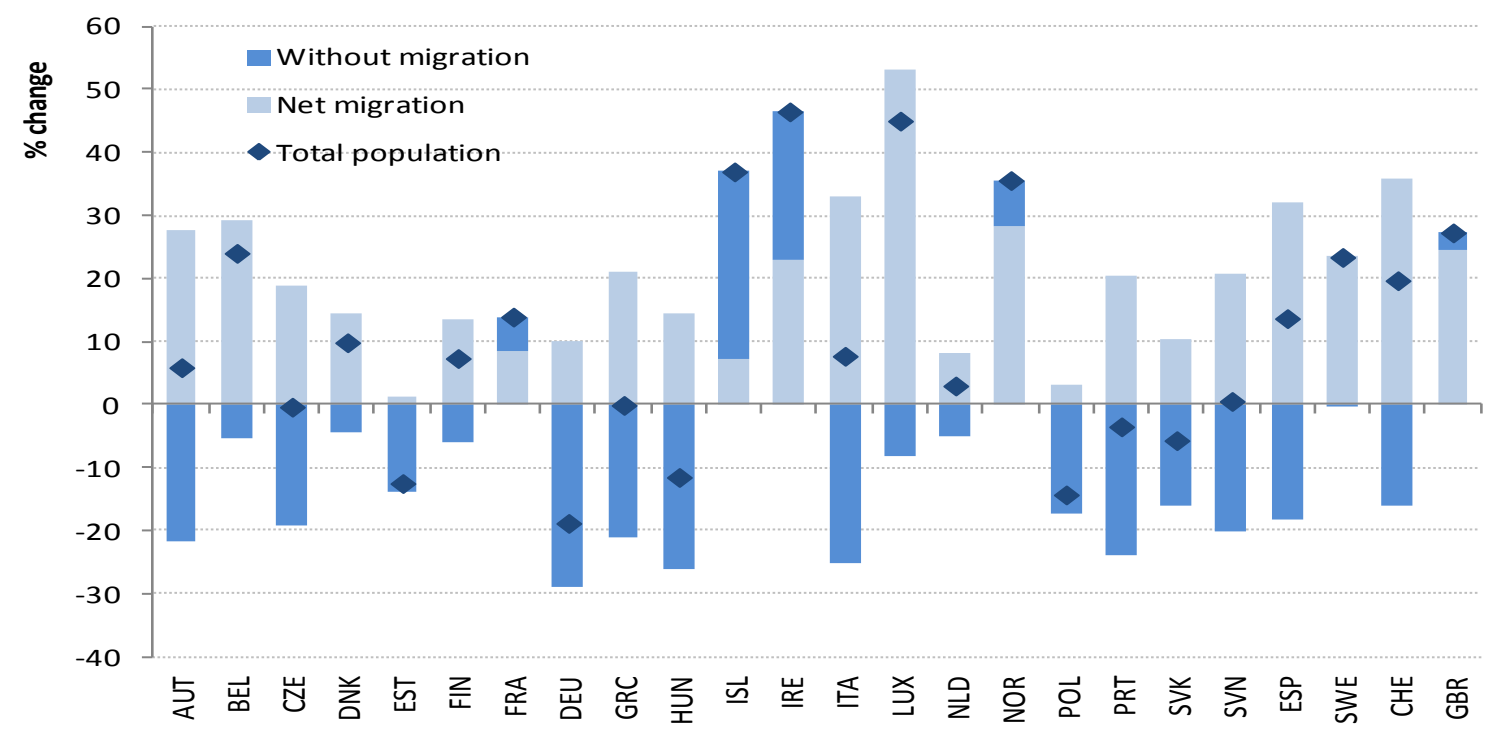

13. Migrants contribute to population growth in two ways. First, they increase total population, and second, they generally have an upward impact on average fertility as fertility of female migrants is generally higher than natives. 
B: Foreign-born population lowers the old-age dependency ratio by around 2 percentage points on average, $2010^{2}$

Ratio of population aged 65 and over to population aged 15-64, per cent

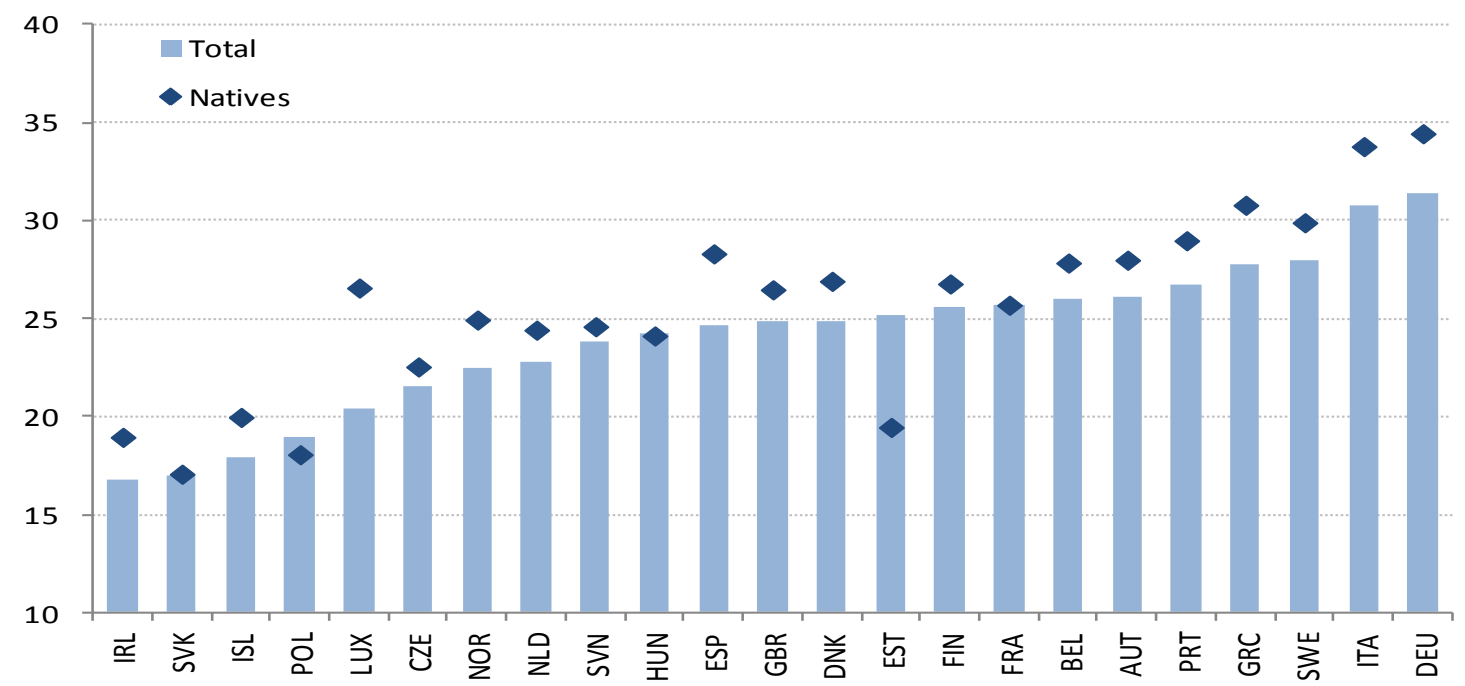

1. Projections assume that past trends in net migration continue and that the age composition of immigrants remains unchanged. The analysis only covers European OECD countries for which data on immigrants by age are available.

2. The Figure shows the old-age dependency ratio in the total population as well as in the native population in 2010, where the difference between the two represents the contribution of foreign-born population.

Source: Eurostat.

\subsubsection{Given ageing trends, structural reforms will be needed to sustain labour force participation}

19. Average labour force participation has remained almost constant over the past decades in several OECD countries, reflecting the offsetting effects of a long-term upward trend in female participation driven by rising educational attainment (Galor and Weil, 1996) and a decline in male participation. ${ }^{14}$ However, in some countries these effects have led to a clear upward trend in participation (e.g. Australia, Canada, Japan, Netherlands and Norway), while in other countries they led to a downward trend (e.g. Czech Republic, Italy, Poland and Turkey). Even though male and female participation rates have been converging in most countries, large cross-country differences in participation still exist across both gender and age groups (Figure 5).

14. In the 12 OECD countries for which data on gender and age-specific labour force participation are available, average labour force participation among women (aged 15 years and above) increased by roughly 8 percentage points (from $47 \%$ to 55\%) between 1980 and 2010. At the same time, labour force participation among males declined by the same amount (from $77 \%$ to $69 \%$ ). These opposite trends may partly be explained by substitution across gender in the labour supply of households (Chiappori, 1988). 
Figure 5. Large cross-country differences in participation among women and older-workers Labour force participation in 2010 (15 years and above), per cent

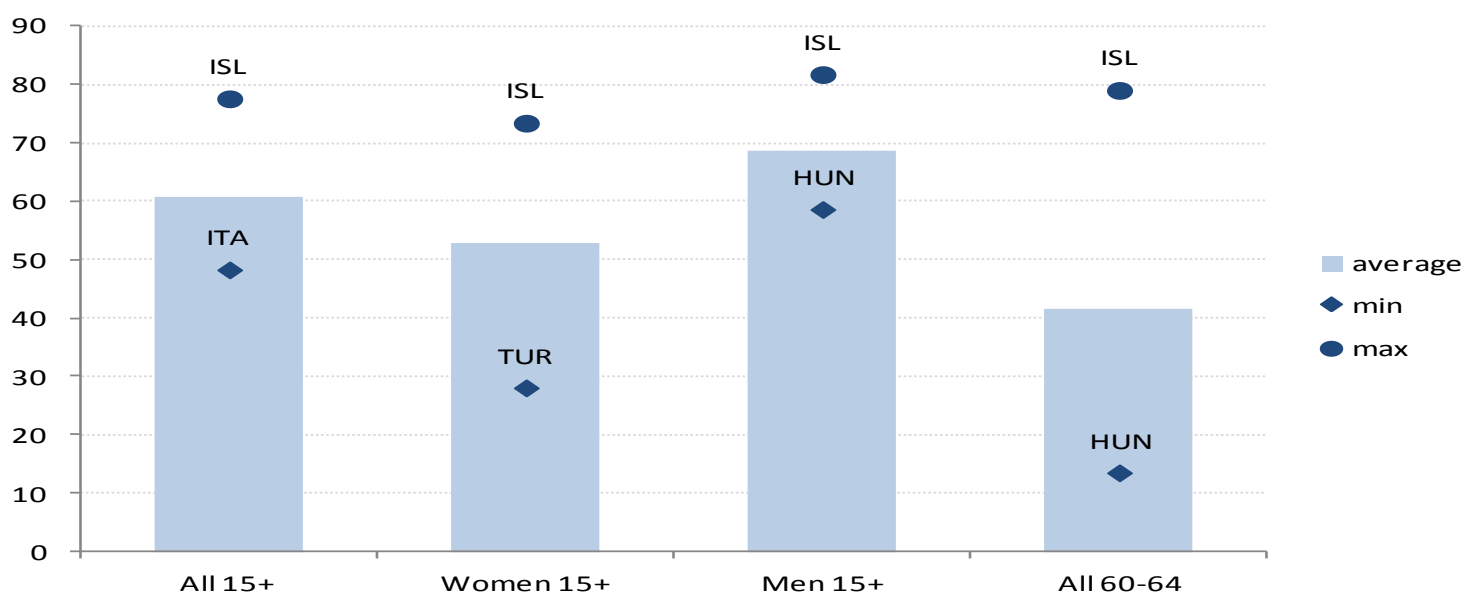

Source: Labour Force Statistics.

20. Using a "cohort" approach (see Box 2), participation is projected to decline sharply in the future due to the combined effect of population ageing and lower participation at older age (Figure 6). The cohort approach assumes that the observed participation behaviour of individuals belonging to the most recent cohorts, such as the lower exit rates of current old-age workers relative to previous cohorts, or the higher entry rates of current young women relative to previous cohorts, will continue to apply to future cohorts as well. Therefore, future participation rates are determined by the participation behaviour of the most recent cohorts and the evolution of the relative weight of different cohorts, which is driven by demographic developments. Although the fall in the exit rate from the labour force at older age together with the increase in participation of women contributed to sustaining aggregate participation in the past, projections suggest that these trends will not be sufficient to offset the adverse effect of population ageing. With unchanged policies, high-income countries will experience an average fall in participation rates among the population older than 15 equal to 5 percentage points by 2060. This decline will be particularly large in the case of Japan, Korea, the United States and some Eastern European countries, whereas it will be more modest for some Nordic countries (e.g. Sweden) or English-speaking countries (e.g. Ireland and NewZealand) that display higher participation rates at older age and/or favourable demographic perspectives. Conversely, middle-income countries such as Mexico and Chile may expect a rise in participation, although this cannot be viewed as a general characteristic of this class of economies. ${ }^{15}$

\section{Box 2. The cohort approach to project labour force participation}

The "cohort approach" (Burniaux et al., 2004) consists in calculating cohort-specific entry and exit rates into or out of the labour force by tracking the participation rates of a given cohort over time, after removing cyclical influences (see Appendix 2). In each OECD country, entry and exit rates into and out of the labour force are calculated by comparing participation rates of a given cohort across two subsequent 5-year periods (e.g. the participation rate of a cohort aged 40-44 in 2012 is compared with its participation rate when aged 35-39 in 2007).

15. The fall in Turkey's participation rate may partly reflect measurement problems. Over the past decades, the migration from rural to urban areas, and more particularly the shift of female workers out of the agricultural sector, has negatively affected the size of the labour force by reducing the number of family workers registered officially in the labour force. 
In a first step which assumes unchanged policies, labour force participation projections are obtained assuming that all future cohorts will display the same exit and entry rates as the ones observed in the most recent cross-section of cohorts. This approach implies that future changes in aggregate labour force participation arise from differences in entry and exit rates across cohorts combined with shifts in the demographic structure of the population. In the baseline scenario, which takes into account developments in education and policy adjustments to respond to ageing, both entry and exit rates depend on education, while exit rates of older workers are adjusted to maintain constant the share of lifetime spent in the workforce. Based on the these entry and exit rates into or out of the labour force, aggregate labour force participation rates are predicted by aggregating cohort-specific participation rates with population shares. In nonOECD countries for which data on labour force by cohort are not available, aggregate participation is predicted using the coefficient estimates from a dynamic panel model that regresses participation rates on education attainment levels, young and old-age dependency ratios and their interaction.

Figure 6. Labour force participation is projected to decline at unchanged policies ${ }^{1}$

Labour force participation among 15+ in a benchmark scenario with unchanged policies, per cent

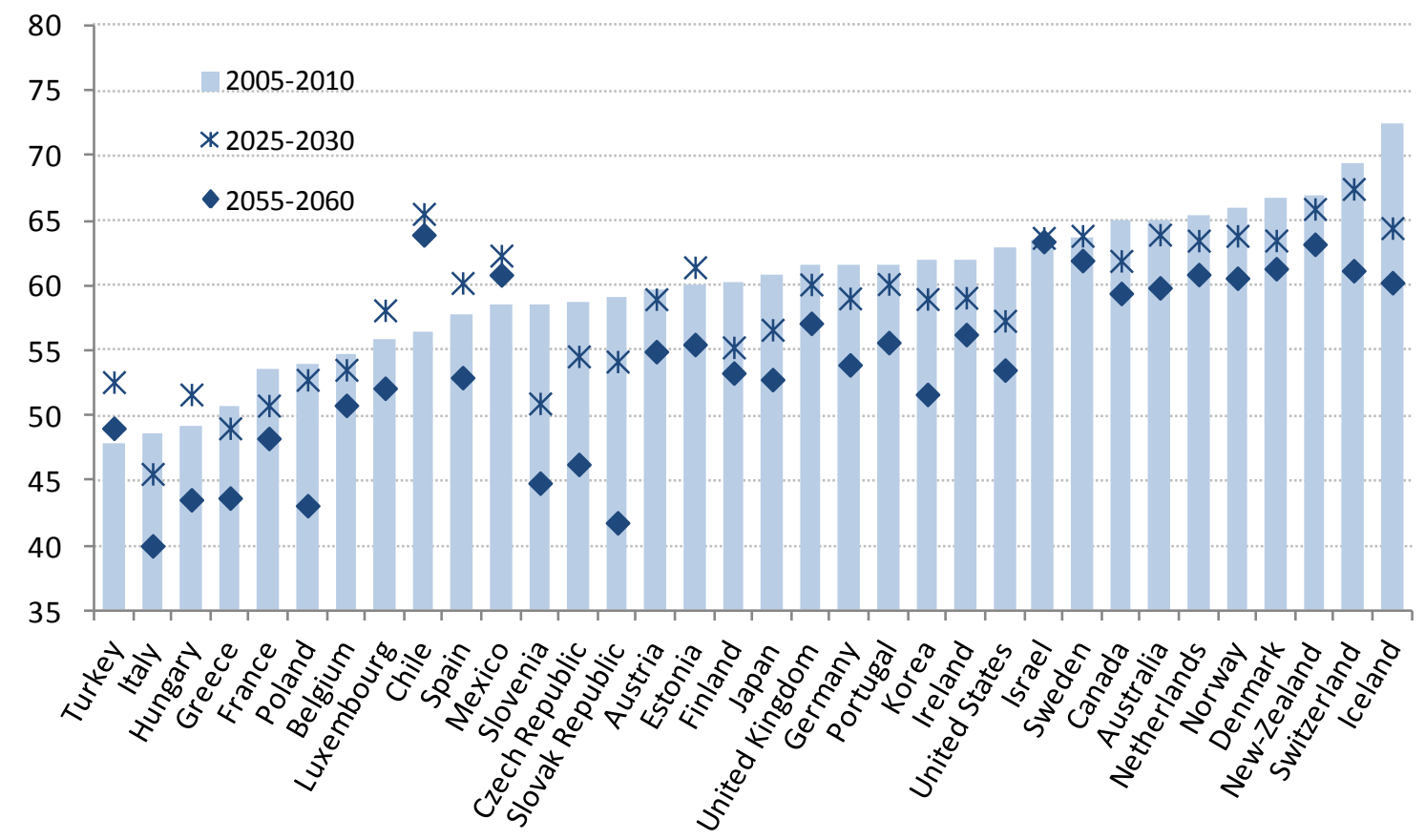

1. This chart shows trends in labour force participation for only the OECD countries for which the cohort analysis is performed. The data show the average labour force participation over five years to match the cohorts which are in five-year intervals.

21. Given the strong downward effect of ageing on labour force participation, structural policy reforms will be needed to sustain aggregate participation rates in the future. First, the long-term trend expansion in education -- and the associated increase in average years of schooling -- is assumed to continue in all countries (see below). An increase in educational attainment has two countervailing effects on aggregate labour force participation of the population aged 15 and above. On the one hand, more time spent in school lowers the entry rate of younger cohorts into labour force. On the other hand, educated workers are more likely to enter the labour force once they have completed their education and possibly also less likely to exit the labour force at older age. Due to these offsetting forces, the projected increases in educational attainment only moderately raise aggregate labour force participation rates, on average by 0.5 percentage points by 2060, although the effect is noticeably larger in some countries (e.g. Turkey, Mexico, Korea, Italy and Hungary). 
22. Second, longer life expectancy and health improvements raise the scope for policies that encourage higher labour market participation at older age. A number of policy incentives can be put in place to this effect. The labour force exit rate for the cohort aged 60-64 varies widely across countries, ranging from $10 \%$ in Iceland to $70 \%$ in France (Figure 7) and this can be partly explained by differences in policy settings. For instance, empirical evidence (see Appendix 4 for details) suggests that a reduction in the implicit tax on continued work and an extension of the legal age for claiming full-rate retirement (particularly for women whose legal age is on average one year lower than for men) would increase participation rates.

Figure 7. Older-workers exit the labour force at high rates in some countries

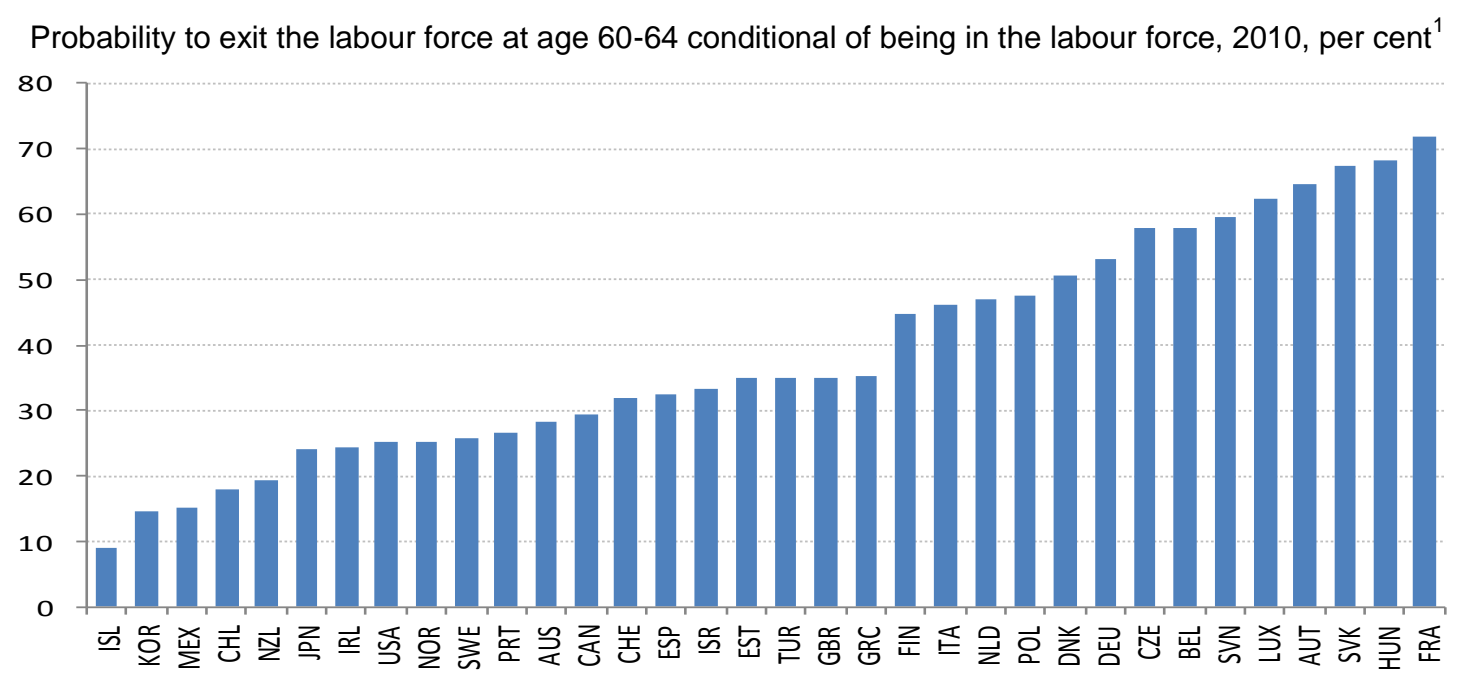

1. A higher number denotes greater probability to exit the labour force.

23. A number of countries have already implemented or plan to implement reforms aiming to extend working lives, including by increasing the legal age to get a full pension. Recently-legislated pension reforms that involve an increase in the normal retirement age by 2020 are assumed to be implemented as planned, which lowers exit rates for the 50-64 age group in the countries concerned according to estimated elasticities and, thus, raises overall participation rates. ${ }^{16}$ On average, these reforms raise total labour force participation in 2060 by 0.7 percentage points. More generally, one way to envisage the outcome of structural policies aimed at sustaining labour force participation in the face of ageing is to assume that, over the projection period, the share of lifetime spent in the labour force remains unchanged despite gains in longevity. ${ }^{17}$ The average, hypothetical, "active life expectancy" (i.e. the average duration of active life) varies widely across countries. Today, workers in OECD countries spend on average 35 years in the labour force, ranging from 21 years in Turkey to 40 years in Iceland. When this duration is converted into a share of current life expectancy at birth, workers are found to spend on average $43 \%$ of their life span in the

16. Legislated increases in pensionable age are from OECD (2012). The countries for which an adjustment on current exit rates of older workers are made include Australia, Belgium, Canada, Czech Republic, Germany, Spain, Estonia, France, the United Kingdom, Greece, Hungary, Ireland, Israel, Italy, Japan, New Zealand, Slovak Republic, Slovenia, Turkey and the United States.

17. Active life expectancy is a counterfactual construction that reflects the average number of years that a hypothetical worker would spend in the labour force if he/she would face the same entry, exit and participation rates observed today during his/her entire active life. The calculation of active life expectancy relies on the age- and gender-specific probabilities of entering and exiting into/from the labour force and the accompanying participation rates (see Appendix 3). It is similar to the calculation of life expectancy, which represents the average life time of a hypothetical person facing currently observed mortality rates. 
labour force, a proportion that ranges from below $35 \%$ in Turkey and Italy to $50 \%$ in Iceland. In the baseline scenario, it is assumed that countries will implement the necessary reforms to maintain the average time spent in the labour force fixed as a proportion of life expectancy at birth. In other words, the average duration of active lives will lengthen, but comparatively less than life expectancy and no convergence in active life expectancy among countries is envisaged. Nonetheless, increasing the duration of active life in proportion to gains in life expectancy would likely require considerable efforts in some countries. On average, with life expectancy being projected to increase by 5.8 years until 2060, active lives will need to increase by 2.5 years in order to keep the average ratio of active life to life expectancy in OECD countries constant.

24. Under these assumptions, the aggregate OECD labour force participation rate (among the population older than 15 years) is projected to stay roughly constant at the current $60 \%$ level in the baseline scenario. However, maintaining a constant share of life spent in the labour force does not imply a fixed labour force participation rate, as the latter also depends on the relative weight of the different age groups in the population. Consequently, there are countries in which participation is still projected to fall (e.g. Poland, Korea, Portugal, Japan and Slovenia), and others in which participation is projected to increase (e.g. Chile, Estonia, Turkey, Mexico and the United States) (Figure 8).

Figure 8. Labour force participation is projected to change relatively little in the baseline scenario ${ }^{1}$ Labour force participation among $15+$ in a baseline scenario, per cent

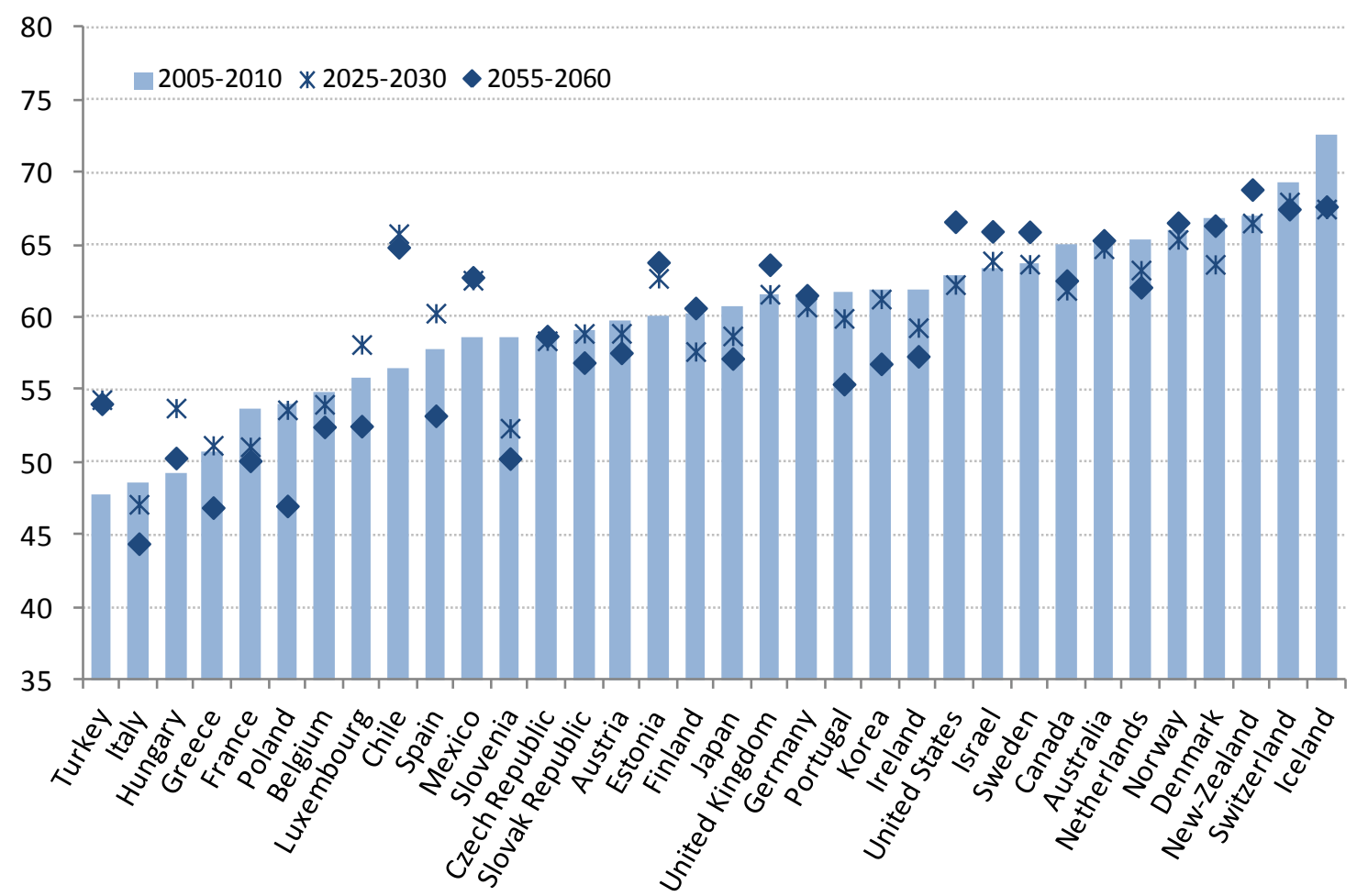

1. The baseline scenario assumes that educational attainment continues to increase and policy reforms are implemented to change exit rates so that "active life" remains a constant share of life expectancy. It also accounts for recent changes in pension age for current exit rates of older workers. This chart only shows trends in labour force participation for OECD countries for which the cohort-analysis is performed. The data shows the average labour force participation over five years to match the cohorts which are in five-year intervals. 


\subsubsection{Unemployment will gradually return to pre-crisis levels}

25. In the long run, it is unlikely that population ageing will have a large impact on the level of unemployment. Past studies did not detect significant effects of the age structure of the workforce on the rate of unemployment (e.g. de Serres et al., 2012). Whereas the stock of unemployed workers may not be affected by population ageing, some evidence suggests that average worker turnover may decrease as older workers display lower entry and exit rates into/from unemployment, which in turn may increase the risk of cyclical unemployment becoming structural. On the other hand, lower turnover among older workers may decrease transitory unemployment. The consequences of this structural change cannot easily be captured in the long-term projections as the set-up does not account for long-term economic volatility. ${ }^{18}$

26. In the medium term, however, many countries face a risk of high unemployment persistence and high structural unemployment. Approximately 14 OECD countries have experienced an increase in unemployment larger than 2 percentage points compared with pre-crisis levels, and long-term unemployment has risen sharply in some countries, such as France, Italy and the United States (de Serres et al., 2012; OECD, 2011d). For those cohorts of workers who are disproportionately affected by the economic crisis, namely young and low-skilled workers, there is a high risk of unemployment persistence over the medium term, especially because the probability of leaving unemployment depends negatively on the time spent in unemployment (Van den Berg and van Ours, 1996).

27. Against this background, the baseline scenario assumes that trend unemployment rates will gradually return to their long-run levels, at a speed of convergence that is estimated from a panel data model (see Appendix 5 for details). In each country, the target long-term level of unemployment is chosen to be the lowest value of trend unemployment between 2007 and 2013. ${ }^{19}$ Persistence in (trend) unemployment, which in turn determines the speed at which a country converges back to its pre-crisis level, depends on a number of labour market policies and institutions (i.e. the tax wedge, spending on active labour market policies and the unemployment replacement rate). For example, trend unemployment in Spain increased by about 31/2 percentage points between 2007 and 2011, reaching 16\%. Simulations suggest that it will decline to $14 \%$ by 2015 and almost return to its 2011 level by 2020 . For non-OECD countries, a different set-up is applied, reflecting the fact that trend unemployment is currently comparatively high in some of these countries and that downward adjustments will likely take place as economies develop. Therefore, where trend unemployment is currently above the OECD average (e.g. Argentina, Brazil, the Russian Federation and South Africa), it is assumed to gradually converge to this OECD average. In countries where trend unemployment is currently below the OECD average, it remains unchanged.

\subsubsection{Human capital will continue to improve}

28. Since the end of the $19^{\text {th }}$ Century, educational attainment has converged across high- and medium-income countries (Morrisson and Murtin, 2009). ${ }^{20}$ Educational attainment (measured by average

18. Indeed, older workers display intrinsically lower entry and exit rates into/from unemployment (Murtin et al., 2012), which allows for the possibility that population ageing may soften labour market dynamics in the future. For instance, Aaronson et al. (2010) argue that one third of the trend decline in the unemployment exit rate in the United States between the mid-1980s and the mid-2000s was caused by ageing of the workforce.

19. In the case where trend unemployment in 2013 is already below its pre-crisis level, such as in Germany, it is assumed to remain unchanged.

20. During the 1870-1913 period, convergence in average years of schooling among the adult population took place at a pace of $3.7 \%$ annually (which corresponds to an initial gap being closed by half within 19 years), but it only involved a limited number of high-income countries. After 1960, the convergence club included 
years of schooling) has increased on average by four years over the period 1970-2010, with particularly large up-skilling in countries starting out from very low levels of education in the 1970s (e.g. Korea, Indonesia, China, Turkey and Brazil) (Figure 9). There are at least two intrinsic factors explaining the convergence in educational attainment. First, marginal returns to education are generally decreasing both at the microeconomic and macroeconomic levels (Mincer, 1974; Psacharapoulos and Patrinos, 2004), and second, the marginal cost of education rises with attainment. From that perspective, it is legitimate to conjecture that convergence in average years of schooling will continue over the next 50 years.

Figure 9. Educational attainment has increased over time

Average years of schooling of the adult population

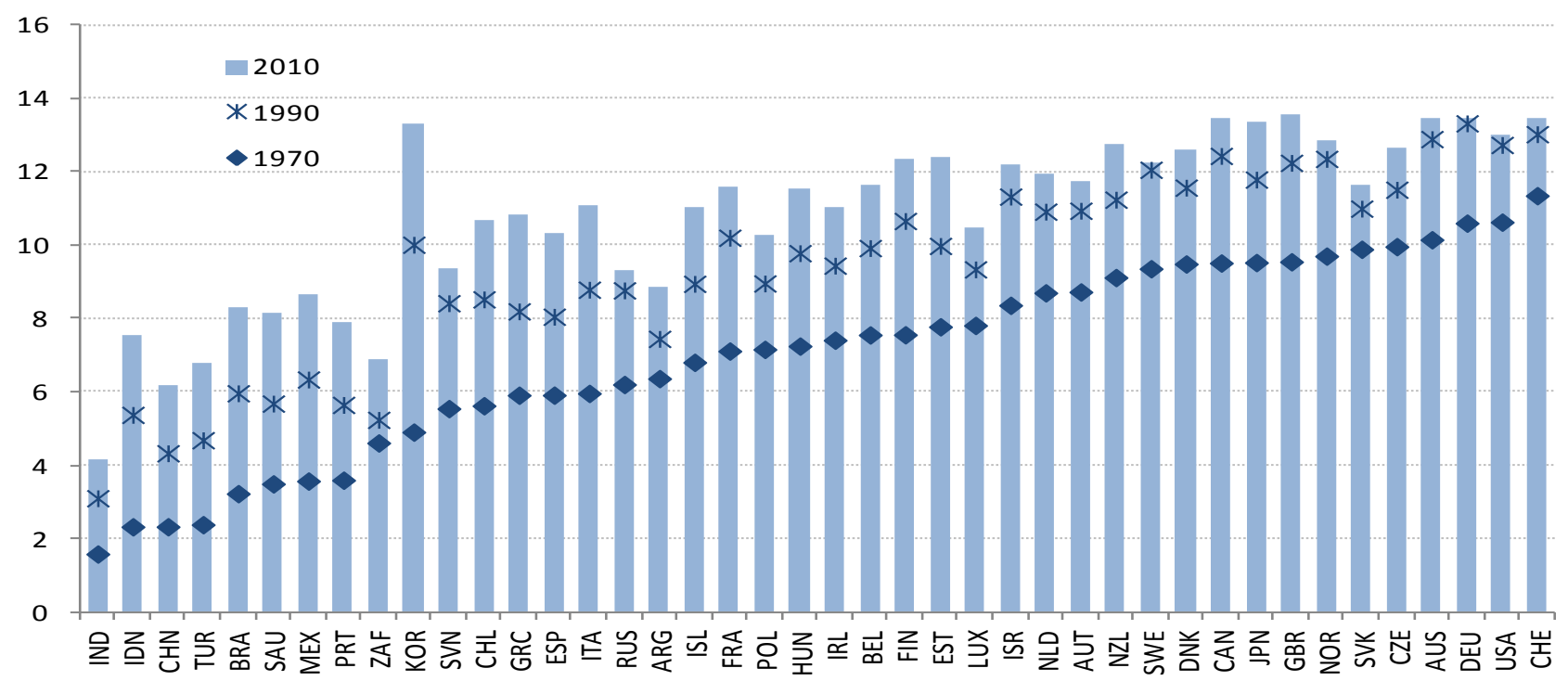

29. The baseline scenario, therefore, assumes that educational attainment of cohorts aged 25-29 slowly converges in all countries towards the world frontier (Korea) at the average speed observed globally over the period 1960-2005, with attainment in Korea also continuing to rise slowly through 2060 (to $72 \%$ of persons aged 25-29 having obtained tertiary education from 63\% in 2009). Based on these assumptions, future educational attainment of the adult population is projected using a perpetual inventory method to take demographic developments into account. Average years of schooling of the adult population thus increases by two years on average over the period 2011-2060, compared with an increase of four years over 1970-2010. Increases in education over the projection period are particularly sizeable in India, China, Turkey and South Africa (Figure 10). However, large differences in average education persist in the long term, as the stock measure of education involves the whole adult population and displays sluggish dynamics. The projected evolution of the stock of average years of schooling among the adult population is converted into a human capital stock based on an assumption regarding the associated wage premium, the so-called Mincer return to education (see Appendix 6). This assumption is consistent with a 10-13\% average return to primary education and a 6-7\% return to upper-secondary and tertiary education, in line with microeconomic and macroeconomic evidence. ${ }^{21}$

a much larger set of countries, although convergence took place at a lower speed $(0.7 \%$, or a gap closing by half within 99 years).

21. The baseline scenario relies on existing microeconomic evidence on returns to schooling for a large set of countries, which estimates the return to schooling as return $=0.125-0.004 *$ average years of schooling (Morrison and Murtin, 2010). 
30. Policy-wise, the baseline scenario therefore implicitly embeds a continued expansion of educational systems. However, this does not necessarily imply increasing public expenditure for public education. For instance, a recent OECD study (OECD, 2008b) forecasts stable or decreasing public expenditure (as share of GDP) for tertiary education, even after assuming ongoing expansion in higher education, with some notable exceptions (e.g. Austria, Denmark, Sweden, Iceland, Mexico or the United States). This partly reflects the decreasing size of young cohorts in some countries (e.g. Czech Republic, Germany, Japan, Korea, Sweden or Switzerland) and shifts in the shares of private versus public funding.

Figure 10. Convergence in education across countries

Average years of schooling, 25-64 years old

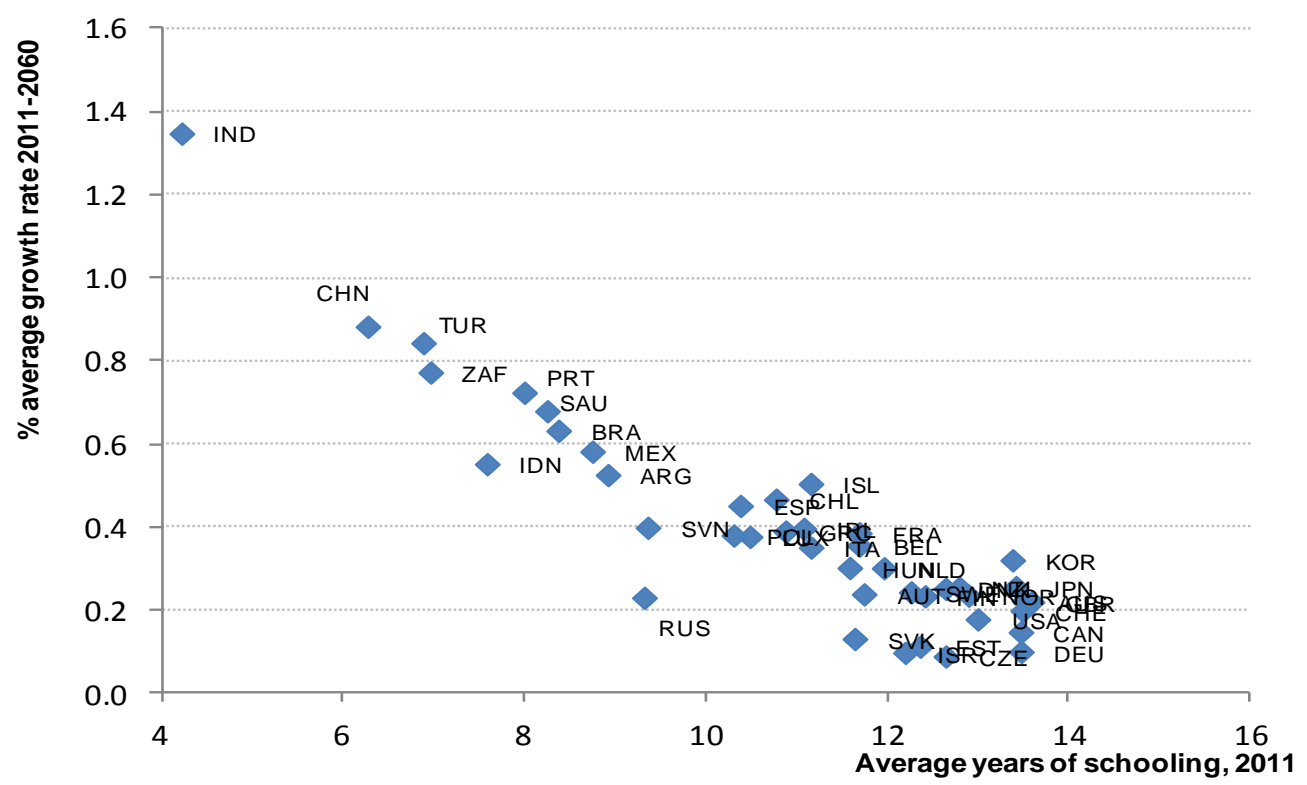

\subsubsection{Capital intensity is assumed to gradually stabilise}

31. In most, but not all, developed economies, the ratio of (non-residential) productive capital to trend output has been relatively stable (Figure 11), particularly those for which explicit data on capital stocks are available from national accounts. ${ }^{22}$ For most countries, the underlying projection for capital therefore assumes a continuation of this stability in capital intensity. On the other hand, there are a number of countries where capital intensity has shown a definite recent trend, and where this is the case, the trend is assumed to gradually disappear so that the underlying capital-output ratio stabilises. ${ }^{23}$ Australia and Canada are examples among OECD countries where recent capital deepening is probably related to the commodities boom in mining, and China and India are important examples among emerging countries.

22. The productive capital stock is defined here to exclude housing. But for some (mostly non-OECD) countries, the housing component of investment has to be estimated. Moreover, for countries for which there is no official data on productive capital stocks, these stocks are built up from investment series (excluding residential housing investment) through the perpetual inventory method, assuming a $4 \%$ annual depreciation rate.

23. Formally, this is achieved by adopting an autoregressive rule whereby the annual change in the ratio of capital to potential output is 0.85 times the change in the previous year (implying that after five years the rate of increase is about half the initial rate). 
32. The projections of the underlying capital-output ratio are then subject to influences from the real cost of capital in a manner consistent with a Cobb-Douglas production function. The main reason for changes in the cost of capital are changes in real interest rates, which vary for a number of reasons, including the cyclical position of the economy, fiscal risk premia and ensuring global consistency between saving and investment (see Box 4). For instance, higher interest rates on rising government debt puts upward pressure on long-term interest rates throughout the economy and so reduce capital intensity. A generalised increase in global interest rates related to a fall in the global saving rate (discussed in later sections) accounts for the slight tendency for capital intensity to decline in most countries towards the end of the baseline projection.

\section{Figure 11. Capital intensity is assumed to broadly stabilise}

Ratios of capital to trend output, for selected countries

A : Countries with recent stability

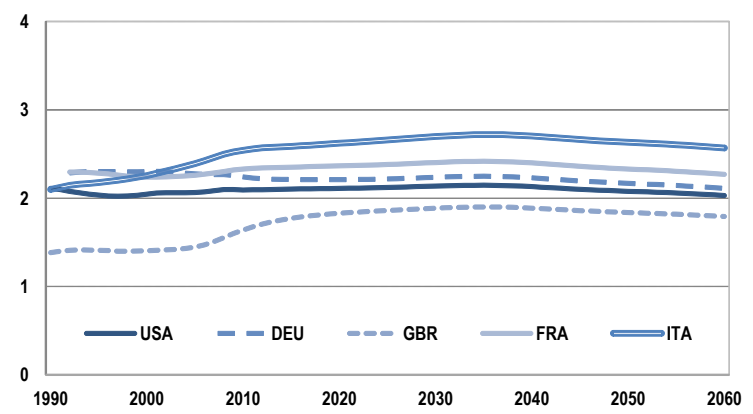

B : Countries with recent increases

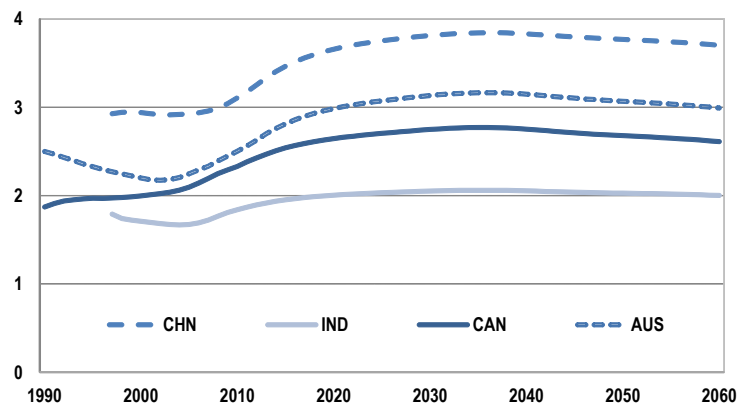

33. Investment projections are backed out from projected capital stocks assuming that depreciation rates remain stable at recent historical levels. There is no influence from structural policies on investment, except indirectly to the extent that they boost output, although this ignores some evidence to suggest that reforms to product market regulation and employment protection legislation can boost investment rates (Alesina et al., 2005; Égert, 2009; Kerdrain et al., 2010). Housing investment is determined separately with the share of housing investment in total investment assumed to return gradually to a 10 -year average. ${ }^{24}$

\subsubsection{Efficiency improvements will be the main driver of growth}

34. As already mentioned, MFP is the main driver of projected GDP per capita growth. MFP projections are driven by the global rate of technological progress, assumed to be $1.3 \%$ per year (corresponding to the average rate of MFP growth observed among advanced economies over the period 1996-2006) and the speed of "catch-up" towards the country-specific steady-state level of MFP, which depends on trade openness and the strength of domestic competition (see Box 3 and Appendix 7 for details). Greater openness to trade increases the speed of convergence towards the technological frontier, thus enhancing MFP growth. In relatively restrictive countries, the baseline scenario allows for slow convergence to product market regulations prevailing in the average OECD country in $2011 .^{25}$ The move to

24. Using the share of housing in total investment, rather than in GDP, as a benchmark reduces the problem of any pre-crisis average being inflated by housing booms in countries like Spain and Ireland.

25. The speed of convergence in regulations is assumed to be equal to half the average speed of convergence in product market regulations among OECD countries over the period 1998-2008, reflecting that the pace of reforms may gradually diminish over time. 
easier product market regulation embedded in the baseline scenario has two effects on productivity: $i$ ) it boosts the long-run (country-specific) target level of MFP; and ii) the resulting increase in the gap between initial and target MFP enhances the contribution of catch-up productivity growth in the transition period, more so in countries where initially stringent regulations depressed beginning-of-period MFP. On average across countries, the estimated speed of convergence is $6 \%$ per year, broadly in line with existing empirical evidence (e.g. Bouis et al., 2011; Bourlès et al., 2010; Fouré et al., 2010), implying that it takes roughly 12 years to eliminate half of the initial MFP gap. But it takes about five more years to close half the initial MFP gap in a country that is half as open to trade as the average country.

\section{Box 3. Policy drivers of MFP in the projections}

Two factors shape projected MFP. First, competition in product markets spurs MFP growth through firm entry, which leads to new quality-improving innovations, strengthens incumbent firms' incentives to adopt leading technologies and innovate and facilitates reallocation of resources to the most productive firms and sectors. Second, international trade openness promotes innovation among firms (Bloom et al., 2009) and enhances the diffusion of leading world technologies (e.g. Aghion and Howitt, 2009). Accordingly, the dynamics of MFP rely on empirical estimates based on a panel covering most of the countries included in this study and a specification that accounts for the effects of international technology spillovers related to trade openness and domestic product market competition policies. The strength of domestic competition is proxied by the OECD indicator of product market regulation (PMR) and trade openness is measured as the ratio of the sum of exports and imports to GDP. The baseline scenario assumes that in countries where regulations are initially more stringent than in the average OECD country, the country-specific PMR slowly converges to the average PMR level.

Apart from these factors, a range of other factors also influences innovation and technological diffusion, such as investment in research and development, the ease in reallocating resources (Andrews and de Serres, 2012) and complementarities between education and innovation (Nelson and Phelps, 1996). However, these links are difficult to explicitly take into account in the current set-up. Initial, unexplained cross-country differences in MFP levels that reflect some of these factors, as well as the quality in human and physical capital, are captured by time-invariant country fixed effects from the empirical model and are also assumed to gradually diminish over time. The rate at which the country fixed effects converge across countries implies that it takes around 27 years to eliminate half the initial gap to the average fixed effects. The country fixed effects imply an average $45 \%$ gap in MFP relative to the average OECD country in 2011 (i.e. the standard deviation of country fixed effects is equal to 0.45 ). In 2060, the average gap implied by country fixed effects has been reduced by a factor 3.5 and is equal to $13 \%$ relative to the average OECD country.

These baseline assumptions imply convergence over time in MFP levels across countries.

35. In this set-up, countries exhibiting comparatively low initial MFP levels -- such as India, China, Indonesia and Eastern European countries -- tend to grow faster than more developed economies (Figure 12). Average annual MFP growth is projected to be $1.5 \%$, ranging from less than $1 \%$ in Luxembourg, Ireland and Israel, to $3.7 \%$ in China. Generally, growth in MFP is projected to initially gradually pick-up until around 2030 and to remain fairly constant thereafter over the projection period. However, in currently fast-growing catching-up countries (e.g. Brazil, China, Czech Republic, Estonia, India, Slovak Republic and Slovenia), MFP growth tends to slow down over the projection period as gaps to steady-state MFP levels close. 
Figure 12. Multi-factor productivity tends to converge across countries over 2011-2060

Initial MFP level and average annual growth in the baseline

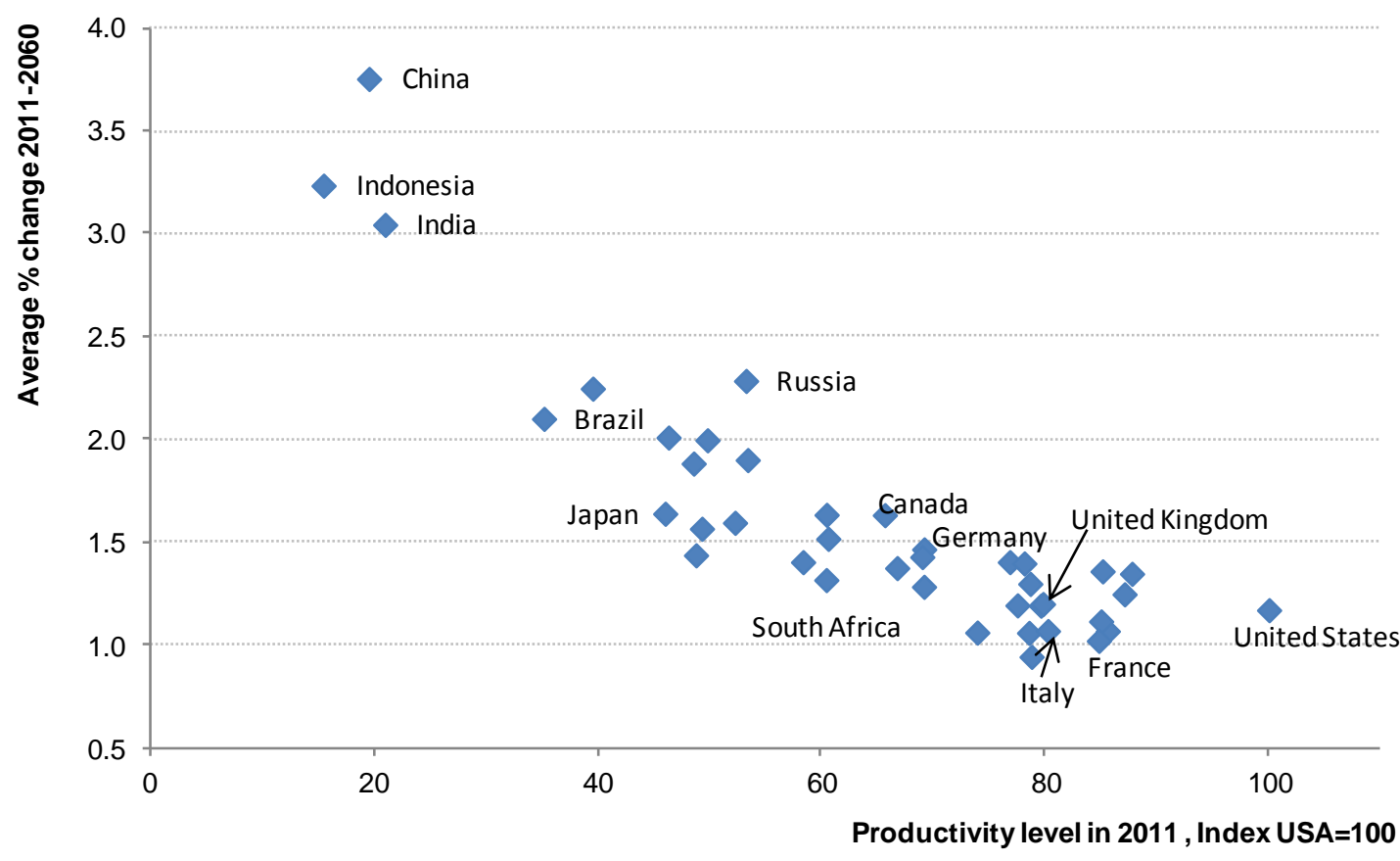

1. PMR regulations are hypothetically eased in restrictive countries to reach the OECD average in the base year (2011) by the end of the projection period.

\section{A globally consistent long-term macroeconomic baseline}

36. The framework described in the previous section is used to generate projections of potential output which are combined with a new model designed to highlight pressures on saving and investment (Box 4) to generate a globally coherent macroeconomic baseline to 2060. Three aspects of this baseline projection are important to highlight: the extent of convergence in living standards; the aggregate growth in GDP and the implied changes in the relative size of economies; and the build-up of macroeconomic imbalances. 
ECO/WKP(2012)77

\section{Box 4. The BLT model}

With potential growth determined according to the convergence framework described in earlier sections of the paper and in Appendix 1, the BLT model projects saving, investment, current account and fiscal imbalances in a globally consistent manner. The level of detail underlying OECD projections is greater than for the non-OECD, reflecting a more complete data set both in terms of fiscal accounts and structural policy settings. Key features of the model are summarised below and described in more detail in Appendix 10.

- Non-housing investment is determined so as to be consistent with projections of capital intensity. Higher real interest rates, by lowering capital intensity, lower the investment share. If the capital-output ratio is stable, then the share of investment depends only on the growth rate of the economy and the rate of depreciation (the latter being held constant at its last estimated value or at $4 \%$ in the absence of historical estimates). Housing investment as a share of total investment is assumed to gradually return to its average level over the decade prior to the crisis.

For OECD countries, private and public saving are distinguished, whereas for non-OECD countries only total national saving is projected given the absence of detailed fiscal accounts.

- $\quad$ For OECD countries, private saving rates are determined according to previous OECD empirical work, with effects from the old-age and youth dependency ratios, life expectancy, fiscal balances, the terms of trade, productivity growth, net oil balances and the availability of credit (see Table 1 of Kerdrain et al., 2010). An explicit effect from the cycle has been added with the inclusion of an estimated output gap term. Total national saving in OECD countries is determined as the sum of public and private saving, although there is a $40 \%$ offset of any improvement in public saving from reduced private saving due to partial Ricardian equivalence (in line with the majority of recent OECD estimates, for example Röhn, 2010).

- For non-OECD countries, the total saving rate is determined according to an equation with effects from the old-age and youth dependency ratios, the terms of trade, the availability of credit, the level of public expenditure (a proxy for public social protection) and productivity growth (see Table 2 of Kerdrain et al., 2010).

- To counter concerns that using an old age dependency ratio with fixed age limits may exaggerate demographic effects on saving over a long projection horizon (especially given longer working lives), an additional effect from life expectancy has been included in the determination of savings for both OECD and non-OECD countries. This effect is based on the empirical findings of $\mathrm{Li}$ et al. (2007), and implies that a one year extension in life expectancy increases the aggregate saving rate by 0.2 percentage points.

Current account balances are determined as follows:

- For most countries, current account balances are determined as the difference between saving and investment. An exception is a group of non-OECD major oil exporters, including Saudi Arabia and Russia, as well as 27 other smaller countries. For this group of countries the current account balance is determined by a dynamic reduced form estimated equation driven by the balance of trade in oil. The latter is determined as the product of the physical volume of net oil exports, which are taken from a recent IEA forecast (IEA, 2011), and the price of oil.

- $\quad$ The global sum of current account balances is kept near zero in relation to world GDP through adjustments to a "global balancing premium" which feeds into the determination of interest rates in all countries. Thus, if there is an ex ante global surplus of savings (i.e. the global current account is moving into increasing surplus) the global balancing risk premium falls, boosting investment relative to saving in all countries so as to stabilise the global current account.

Key features of the fiscal side of the model are as follows:

- The cyclical component of fiscal balances are measured according to a standard OECD methodology 
(Girouard and André, 2005) so that as output gaps close the actual fiscal balance converges to the underlying fiscal balance. Otherwise primary underlying government expenditure and revenue are used to stabilise the government-debt-to-GDP ratio at levels depending on the particular scenario considered. For the baseline scenario this involves gradual consolidation sufficient to stabilise debt (see Box 6) whereas for variant policy scenarios a specific level of debt is targeted.

- The implicit interest rate on gross government debt adjusts gradually to a weighted average of interest rates on treasury bills and on 10-year government bonds as new debt is issued or rolled over. The initial speed of this adjustment reflects the initial maturity structure of debt.

Interest rates are determined as follows:

- $\quad$ Once the output gap has closed and inflation is on target, the level of real short-term interest rates depends on the potential growth rate of the domestic economy plus the "global balancing premium" described above.

- $\quad$ Long-term interest rates are determined as a forward-looking convolution of expected short-term interest rates, plus a fixed term premium (assumed to be 70 basis points) and a fiscal risk premium. The fiscal risk premium is determined in relation to the ratio of gross government debt to GDP; for every percentage point that the debt ratio exceeds a threshold of $75 \%$ the fiscal risk premium increases by 2 basis points, with an additional increase of 2 basis points for every percentage point that the debt ratio exceeds $125 \%$. Japan is assumed to be an exception to this rule because of the high proportion of government debt which is financed from domestic sources (Hoshi and Ito, 2012), so the fiscal risk premium is assumed to be one quarter the size for other countries.

- Inflation, specified in terms of the GDP deflator, is determined from a Phillips curve which includes the output gap and commodity prices. It also includes a term specified as the deviation of the inflation rate from a country-specific target, which implies that once the output gap returns to zero, inflation will eventually return to the target.

\subsection{GDP per capita gaps will shrink but significant cross-country differences will persist}

37. Comparisons of GDP per capita are here made on the basis of 2005 PPPs rather than market exchange rates because they are better suited for comparing living standards, although they are still not without problems (Box 5). Over the projection period, convergence in GDP per capita is expected to take place across countries (Figure 13A). GDP per capita (in 2005 PPP terms), is predicted to grow on average (unweighted) by roughly $2 \%$ annually over the projection period, as against 2.3\% over 1995-2011 (Appendix 8, Table A8.1). The 10 richest countries in our sample of countries (in terms of GDP per capita in 2011) are projected to grow at a rate of $1.7 \%$ per year, whereas growth in the poorest 10 countries is projected to be $3 \%$ annually due to stronger catch-up. Growth in GDP per capita slows down from $2.2 \%$ annually over 2011-2030 to $1.8 \%$ over 2031-2060 as fast-growing "catching-up" countries close income gaps to their long-run steady states. Until 2030, China has the highest GDP per capita growth rate, but after 2030 growth in India and Indonesia is predicted to overtake that in China. This partly reflects a more rapid decline in the working-age population, and consequently in labour force participation, in China than in India and Indonesia. The projections for GDP are broadly in line with previous vintages of OECD projections (see Appendix 8, Table A8.3; OECD 2010). 


\section{Box 5. Market exchange rates versus Purchasing Power Parities}

Purchasing power parity (PPPs) are currency conversion rates that both convert to a common currency and equalise the purchasing power of different currencies. PPPs are therefore better suited than market exchange rates to making cross-country comparisons in living standards because market exchange rates underestimate current relative output levels of low-income countries and thus exacerbate cross-country income differences (e.g. Nordhaus, 2007). The bias arises because non-tradable goods tend to be relatively less expensive in low-income than in high-income countries (i.e. the Harrod-Balassa-Samuelson effect). In addition, market exchange rates are often volatile and affected by political and financial factors that do not lead to immediate changes in living standards. For this reason PPPs are used to assess the impact of long-term economic convergence on relative living standards. On the other hand, when looking at aggregate saving, investment or global imbalances, it makes more sense to use market exchange rates because these are the rates at which savings in one country could be converted and invested in another country, and thus give a more accurate measure of pressures acting on interest rates.

For the period until the end of the short-term projection horizon (2013), nominal exchange rates are sourced from the latest OECD Economic Outlook. Beyond then, for the majority of OECD countries, they are assumed to keep evolving in line with relative inflation rates, so that a country with generally higher inflation than the United States (which is used as the numeraire) will see its nominal exchange rate depreciate. Thus, without further adjustments, there would be no change in real bilateral exchange rates between most OECD countries.

In the case of non-OECD countries, as well as some OECD countries below a certain real per capita income threshold relative to the United States (taken to be $40 \%$ which includes Chile, Mexico and Turkey), it would be unreasonable to assume no change in real exchange rates over the projection period. Indeed, both economic theory and empirical evidence agree that in fast-growing developing economies, real exchange rates tend to appreciate over time as rapid productivity growth in the tradable sector leads to wage increases in this sector that spill over into higher wages and prices in the entire economy (the Harrod-Balassa-Samuelson effect mentioned above) (Frankel, 2006). Rogoff (1996) estimated that for every $1 \%$ increase in a country's real GDP per capita relative to the United States, the real exchange rate increases by about $0.3 \%$. This estimate is used to determine projections of real dollar exchange rate appreciation depending on the speed of income convergence. Projections also involve a gradual correction of the initial level of the real exchange rate compared to its predicted level on the basis of the Harrod-Balassa-Samuelson effect (see Appendix 10 for technical details).

Taking into account real exchange rate appreciation makes projected shares of non-OECD economies in the world economy at market exchange rates increase by more than when using fixed PPPs, albeit shares based on market exchange rates are initially lower for the reasons mentioned above.

Caveats remain regarding comparisons of living standards at fixed 2005 PPPs, however, for they implicitly assume that the composition of the PPP basket will not change in the future and that overall price inflation for this basket in a given country will equal general output price inflation in that country. It is likely, however, that consumption in the future might diverge substantially from the composition of the 2005 PPP basket and that output prices may evolve differently than the prices of this basket's items, especially in rapidly growing countries. For instance, one would expect that as relatively poor economies catch up, the share of their non-tradable sectors in total output would increase, whereas the share of non-tradables in the 2005 PPP basket is by definition constant.

38. Over the projection period, MFP is the main driver of growth - accounting for on average 1.5 percentage points of annual growth -- reflecting the expansion of the global technology frontier as well as catch-up towards countries' long-run MFP levels. In several countries with initially low levels of education, particularly in India, Turkey, China, Portugal and South Africa, the contribution of human capital to annual GDP per capita growth is more than 0.6 percentage points, driven by fast catch-up (Figure 13B). Even so, gaps in human capital with advanced economies close more slowly than productivity gaps. This suggest that major educational reforms, to facilitate more rapid advances in average educational attainment, could be an important policy lever to achieve faster catch-up in living standards among developing countries. Even though the baseline scenario assumes that retirement age increases to maintain the average share of life time spent active constant, labour utilisation will generally not contribute 
to economic growth over the projection period, except in a few countries where participation rates increase due in part to favourable demographics, notably Mexico, India, South Africa, Turkey and Saudi Arabia.

Figure 13. Convergence in trend GDP per capita across countries is mainly driven by MFP

A: Initial GDP per capita in 2011 and annual average growth rate 2011-2060

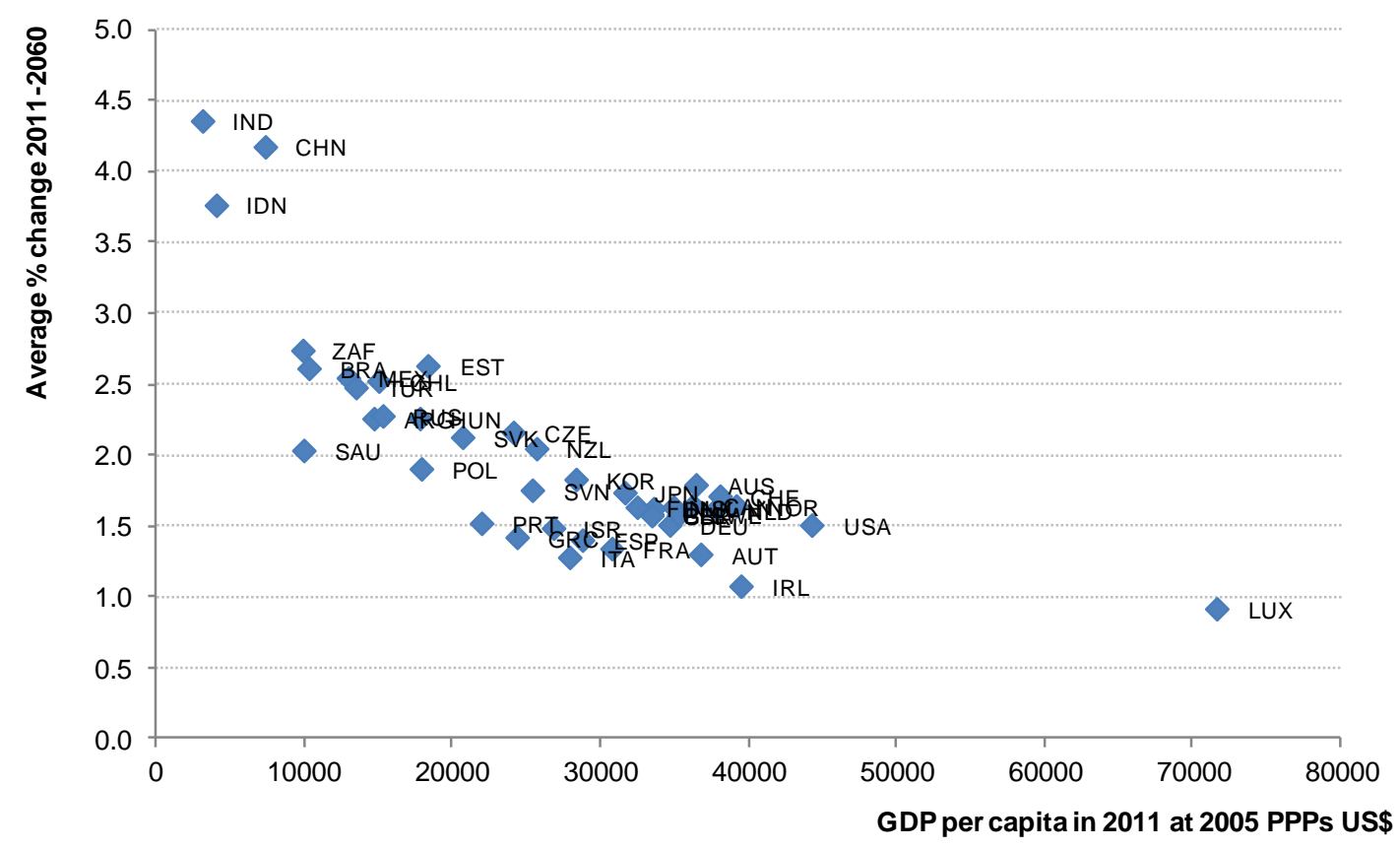

B: Contribution of drivers of growth to annual average trend GDP per capita growth $2011-2060^{1}$

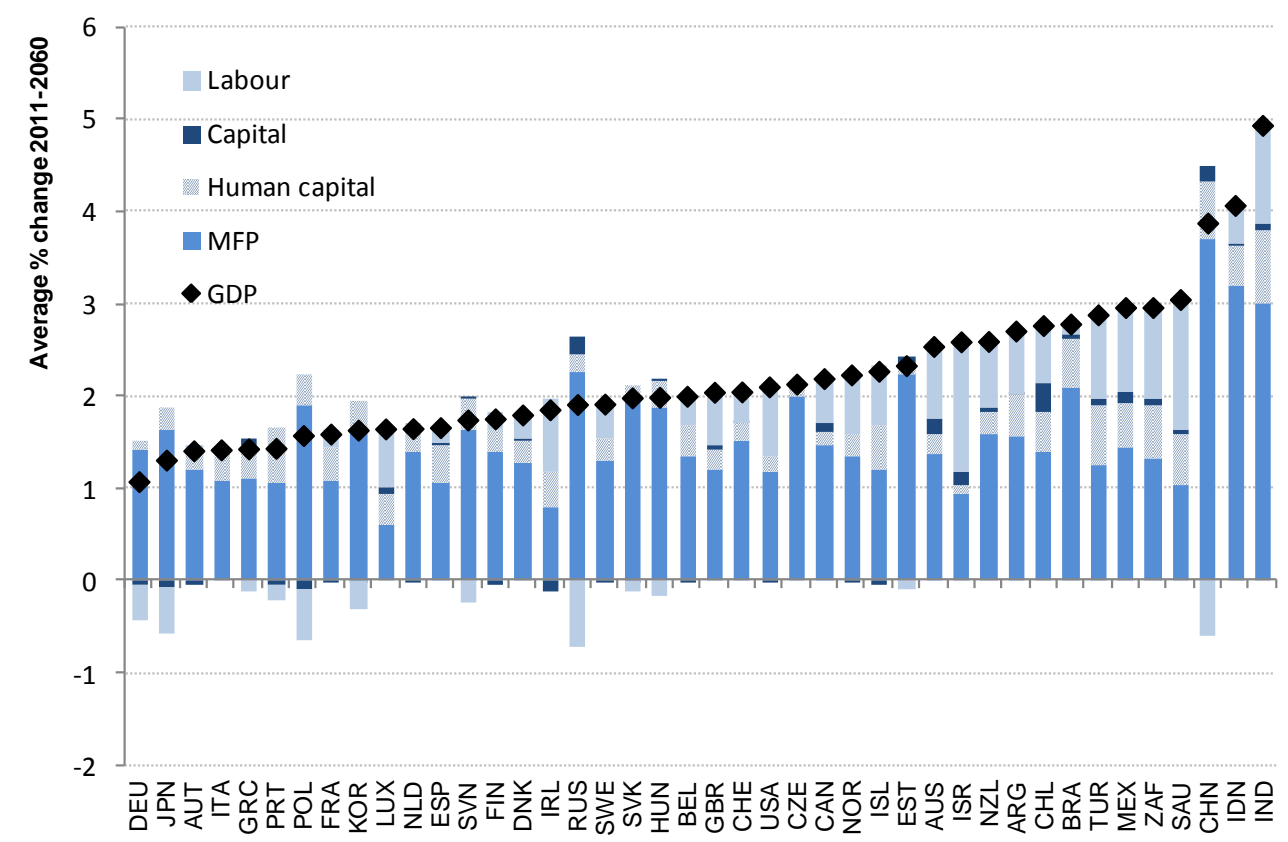

1. To ensure that the percentage gap in the components of GDP add up to GDP per capita, the decomposition is done in log point differences since the decomposition is multiplicative. GDP per capita is equal to the product of the components MFP, human capital, (physical capital/GDP) ${ }^{\alpha /(1-\alpha)}$ and employment/population. 
39. Nevertheless, despite fast output growth among "catching-up" countries, large differences in GDP per capita are projected to persist across countries in 2060 (Figure 14) -- the correlation between the ranking of GDP per capita in 2011 and 2060 is $0.9 .{ }^{26}$ However, much of the income differences will have been reduced when compared with 2011, with the most noticeable improvements in emerging economies. Over the projection period GDP per capita in the 10 poorest economies in our sample more than quadruples (in 2005 PPP terms), whereas it only doubles in the 10 richest economies (see Appendix 8, Table A8.2). China and India experience more than a seven-fold increase of their income per capita by 2060, which roughly brings China 25\% above the current (2011) income level of the United States, although income per capita in India reaches only around half the current US level. The extent of the catchup is more pronounced in China than in India reflecting the momentum of particularly strong productivity growth and rising capital intensity over the last decade. Despite continued convergence in productivity, in a few European countries (e.g. Italy, Spain and Belgium) GDP per capita deteriorates relative to the United States over the projection period, mainly due to weaker labour utilisation driven by low participation at older ages in combination with ageing. This in turn highlights the potential importance of labour market policies, particularly those which influence retirement decisions, in determining the future relative position of GDP per capita among rich economies.

Figure 14. Despite substantial gains by emerging countries differences in GDP per capita still remain in 2060

Contribution of production factors to differences in trend GDP per capita relative to the USA (constant 2005 PPPs)

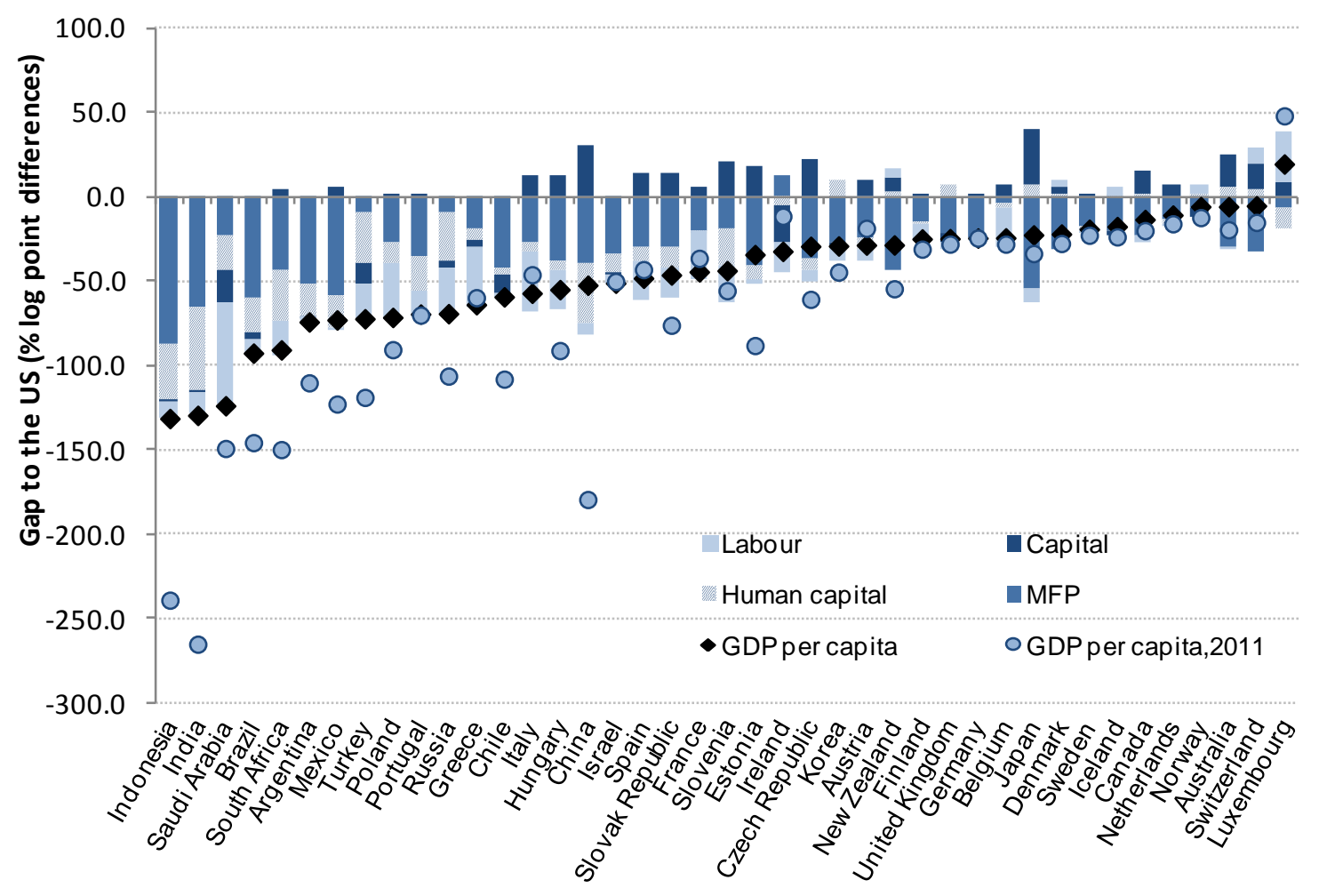

1. To ensure that the percentage gap in the components of GDP add up to GDP per capita the decomposition is done in log point differences since the decomposition is multiplicative. GDP per capita is equal to the product of the components MFP, Human capital, (Physical capital/GDP) ${ }^{\alpha /(1-\alpha)}$ and employment/population.

26. One caveat to these comparisons of GDP levels is that using fixed base year PPPs may bias comparisons far into the future (as discussed in Box 5). 


\subsection{The relative size of economies will change dramatically}

40. The aggregate potential GDP growth rate of the OECD is projected to remain at about $13 / 4$ to $2 \frac{1 / 4}{4}$ per cent per annum to 2060, whereas that of the non-OECD is projected to decline steadily from 7-8\% per annum over the last decade to $4-6 \%$ per annum in the 2020 s and $2-3 \%$ per annum in the 2040s (Table 1). Until 2020, China will have the highest growth rate of any country, but it will then be surpassed by India and by Indonesia a few years later. The potential growth rate of world GDP declines gradually as the contribution from the non-OECD economies from their rising share in the global level of output partially compensates for their declining growth rate.

41. The next 50 years will see major changes in country rankings and shares of world GDP (Figure 15). On the basis of 2005 PPPs, China is projected to surpass the United States in 2016 to become the largest economy in the world and India is about now surpassing Japan. Again on the basis of 2005 PPPs, the faster growth rates of China and India imply that their combined GDP will exceed that of the major seven (G7) OECD economies by around 2025 and by 2060 they will be 1.6 times larger, whereas in 2010 they accounted for less than one half of the G7's GDP. On the basis of nominal GDP converted at market exchange rates (rather than 2005 PPPs), it will take longer for non-OECD countries to catch-up with leading OECD countries, but the changes over time are even more striking because they allow for the projected appreciation of real exchange rates in catch-up countries. Using market exchange rates, China will only surpass the United States in the early 2020s and India will only surpass Japan in the late 2020s, but the combined GDP of China and India will grow from one-quarter the size of the G7 in 2010 to exceed them by 2040 . 
Figure 15. There will be major changes in the composition of world GDP
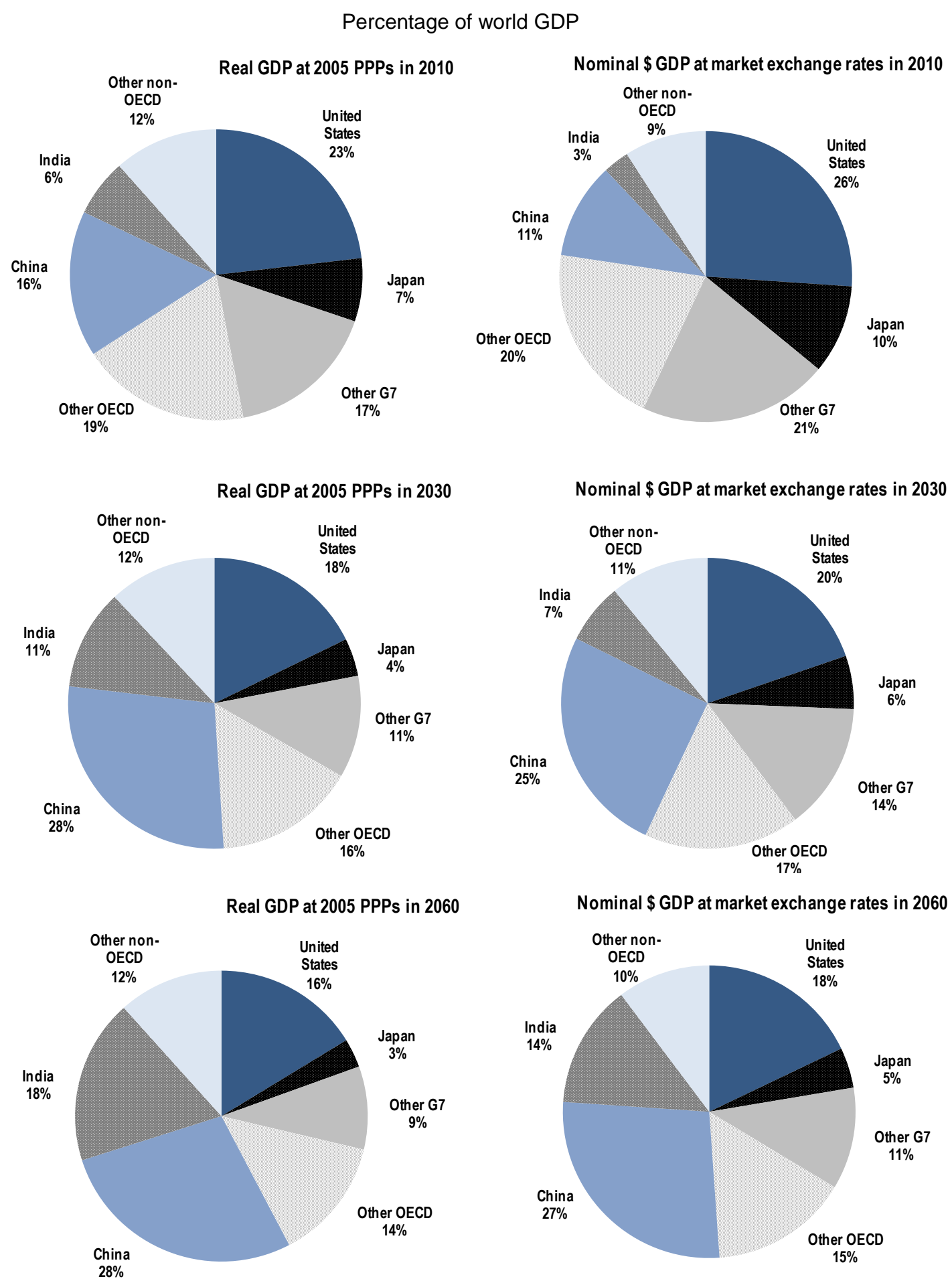

Note: World GDP is taken as sum of GDP for all countries which are distinguished in the model. 


\subsection{Macroeconomic imbalances will build up without strong policy actions}

42. The macroeconomic baseline projections (summarised in Table 1) include the build-up of a number of major imbalances including: high and widespread government indebtedness; the emergence of large global current account imbalances; and, over the longer term, upward pressures on interest rates from declining global savings. They should, however, be viewed as identifying future tensions which may need to be addressed by policy rather than most-likely outcomes, not only because projections made over several decades are inevitably subject to huge uncertainty, but also because no specific policy response to these tensions is built into the baseline (the main assumptions are summarised in Box 6).

\section{Box 6. Assumptions underlying the baseline projections of growth, savings and investment}

The baseline represents a stylised scenario that is conditional on the following assumptions for the period beyond the short-term projection horizon that ends in 2013:

- The gap between actual and potential output in both OECD and non-OECD countries is gradually eliminated from 2013, for most countries within four to five years, depending on the size of the initial output gap.

- $\quad$ The upward pressure on oil prices, on which the short-term projections are based, is assumed to continue for the remainder of the decade, but is thereafter assumed to be mitigated by a supply response. Hence, an increase in real oil prices by about 5\% per annum is assumed from 2013 to 2020, 2\% per annum from 2020 to 2030 and $1 \%$ per annum thereafter.

- Bilateral exchange rates between most OECD countries remain unchanged in real terms. The real dollar exchange rate for non-OECD countries, as well as those OECD countries below a certain real per capita income threshold relative to the United States (taken to be $40 \%$, and so including Chile, Mexico and Turkey), appreciate in line with convergence in living standards, through the so-called Harrod-BalassaSamuelson effect, based on the empirical work of Rogoff (1996) and Wilson et al. (2011).

- The availability of private sector credit in the economy (relative to GDP) is assumed to gradually catch-up with the situation in the United States -- where private credit is assumed to remain constant at around $200 \%$ of GDP -- with the gap assumed to close at $2 \%$ per annum. For example, this means that for an average of the BRIC countries, the availability of credit rises from just over one-third of that in the United States in 2010 , to around three-quarters in 2060 . The wider availability of credit in turn reduces precautionary savings and saving that reflects repressed consumption (in the case of the BRIC countries saving rates fall by about 3-4 percentage points).

Assumptions regarding monetary and fiscal policy are as follows:

- Policy interest rates continue to normalise as output gaps close and beyond that are directed to converge on a neutral real short-term rate, which in turn follows the potential growth rate of the economy.

- The target for inflation is generally taken to be $2 \%$, with the following exceptions: Japan targets $1 \%$; Australia, Poland, Iceland and Norway target 2.5\%; Chile, Hungary, Mexico and Korea target 3\%; Turkey targets 5\%; Argentina, China, India and Russia target 4\% and Brazil, Indonesia and South Africa target $4.5 \%$.

- For those countries where the debt-to-GDP ratio is currently rising, there is a gradual increase in the underlying fiscal primary balance of $1 / 2$ percentage point of GDP per year from 2013 onwards (this is 1 percentage point per annum for Japan given the severity of the task of stabilising debt) through a combination of reduced government spending and higher revenues until the ratio of government debt to GDP is stable given long-term trend growth and long-term interest rates. The rule is symmetric so that countries for which the debt ratio is falling are assumed to undertake gradual fiscal expansion in order to stabilise debt ratios. It should be noted that in many cases this assumption may contradict current government plans and is not necessarily consistent with national or supra-national fiscal objectives, targets or rules. No allowance is made for Keynesian effects of consolidation on demand.

- There are no further losses to government balance sheets as a result of asset purchases or guarantees made in dealing with the financial crisis. No contribution to deficit or debt reduction is assumed from government asset sales.

- Effects on public budgets from population ageing and continued upward pressures on health spending are not explicitly included, or, put differently, they are implicitly assumed to be alleviated through reforms of 
relevant spending programmes or offset by other budgetary measures.

Assumptions regarding structural policies are as follows:

- The share of active life in life expectancy is assumed to remain constant, hence the legal pensionable age is implicitly assumed to be indexed to longevity. In addition, recently-legislated pension reforms that involve an increase in the normal retirement age by 2020 are assumed to be implemented as planned, which lowers exit rates for the 50-to-64 age group in the countries concerned according to estimated elasticities and thus raises overall participation rates. ${ }^{1}$ On average, these reforms raise total labour force participation in 2050 by 0.7 percentage points.

- $\quad$ Structural unemployment in OECD countries gradually returns to the lowest value estimated between 2007 and 2013. Unemployment in non-OECD countries where the level is currently above the OECD average is assumed to gradually converge to the average level of unemployment in OECD countries, while it remains unchanged in countries currently below the OECD average.

- The long-term trend increase in average years of schooling per worker is assumed to continue in all countries, which has two countervailing effects on aggregate labour force participation. On the one hand, a longer schooling period lowers the labour force entry rate of young cohorts. On the other hand, educated workers are more likely to enter the labour force once they have completed their education and possibly less likely to exit the labour force at older age. Due to these offsetting forces, the projected increase in educational attainment only moderately raises labour force participation -- on average by 0.5 percentage points in 2050 , although the effect is noticeably larger in some countries (e.g. Turkey, Mexico, Korea, Italy and Hungary).

- $\quad$ Countries with relatively stringent product market and trade regulations are assumed to gradually converge towards the average regulatory stance observed in OECD countries in 2011. For other countries regulations remain unchanged. This implies faster MFP growth in countries where the regulatory stance is currently more stringent than the OECD average.

- $\quad$ For non-OECD countries, a gradual increase in public spending on social protection is assumed, amounting on average to an increase of four percentage points of GDP to a level of provision similar to the average OECD country. It is further assumed that this is financed in a way in which there is no effect on public saving.

1. Legislated increases in pensionable age are from OECD (2012). Countries for which adjustments to the exit rates of older workers are made on this basis include Australia, Belgium, Canada, the Czech Republic, Germany, Spain, Estonia, France, the United Kingdom, Greece, Hungary, Ireland, Israel, Italy, Japan, New Zealand, the Slovak Republic, Slovenia, Turkey and the United States.

\subsubsection{Government indebtedness will be high and widespread among OECD countries}

43. In the aftermath of the financial crisis, many countries have large fiscal deficits. For the purposes of the baseline, it is assumed that beyond the improvement which results from the operation of the automatic stabilisers as output gaps close, underlying primary balances gradually improve in a manner just sufficient to stabilise gross debt-to-GDP ratios (see Box 6). ${ }^{27}$ Nevertheless, government indebtedness increases substantially relative to pre-crisis levels (Table 1). The OECD government debt-to-GDP ratio increases from a pre-crisis level of 74\% to stabilise at about $113 \%$ of GDP. Moreover, government debt-toGDP ratios are projected to exceed 100\% of GDP in ten OECD countries (compared with just three immediately prior to the crisis), well above levels at which there is some evidence to suggest adverse

27. The implied extent of fiscal consolidation is larger than implied by the rules described in Box 4, because fiscal consolidation would also be required to offset the fiscal implications of ageing populations which are not explicitly incorporated in the framework. On the basis of unchanged policies, public spending on pensions for a typical OECD country could increase by about 3 percentage points of GDP by 2050 (OECD , 2011c) and even under optimistic assumptions about "cost containment" spending on health and long-term care could increase by 3-4 percentage points of GDP to 2050 (Oliveira Martins and de la Maisonneuve, 2006). 
effects on interest rates and growth. ${ }^{28}$ Such adverse effects are, however, only recognised in the model projections here via the effect of higher real interest rates, which occur both at the country level from higher fiscal risk premia and to the extent that fiscal imbalances contribute to an ex ante shortage of global savings and so push up global interest rates.

28. Reinhart and Rogoff $(2009,2010)$ and Kumar and Woo (2010) both find empirical evidence that the growth rate of advanced economies is adversely affected when gross public debt exceeds $90 \%$ of GDP, Cecchetti et al. (2011) find that government debt can be a drag on growth beyond a threshold of $85 \%$ of GDP (2010), whereas Elmeskov and Sutherland (2012) find even lower debt thresholds, of around 40\% and $70 \%$ of GDP, at which growth is adversely affected. Égert (2010), Laubach (2009) and Turner and Spinelli (2011) all find evidence of an effect of government debt on long-term bond yields above a threshold of $75 \%$ of GDP. 
Table 1. Summary of the long-term baseline projections

Percentage of GDP, unless otherwise specified

\begin{tabular}{|c|c|c|c|c|c|c|c|c|}
\hline & Avg 2000-07 & 2010 & 2013 & 2020 & 2030 & 2040 & 2050 & 2060 \\
\hline \multicolumn{9}{|l|}{ United States } \\
\hline Potential real GDP growth (\%) & 2.6 & 1.7 & 2.1 & 2.3 & 2.4 & 2.1 & 1.9 & 1.8 \\
\hline Fiscal balance & -2.6 & -10.7 & -6.5 & -4.1 & -4.1 & -3.9 & -3.7 & -3.5 \\
\hline Gross government debt & 62 & 98 & 111 & 115 & 116 & 117 & 118 & 118 \\
\hline Real interest rate (\%) & 2.4 & 1.7 & 1.4 & 3.4 & 3.6 & 4.2 & 4.4 & 5.0 \\
\hline Total national saving & 14.7 & 12.5 & 12.7 & 11.6 & 9.9 & 9.5 & 9.7 & 9.6 \\
\hline Total investment & 19.7 & 15.8 & 17.0 & 16.3 & 16.3 & 14.0 & 12.8 & 11.4 \\
\hline Current balance & -4.9 & -3.2 & -4.3 & -4.7 & -6.4 & -4.5 & -3.0 & -1.8 \\
\hline \multicolumn{9}{|l|}{ Japan } \\
\hline Potential real GDP growth (\%) & 0.7 & 0.6 & 0.8 & 1.2 & 1.4 & 1.1 & 1.5 & 1.7 \\
\hline Fiscal balance & -5.4 & -8.4 & -10.1 & -7.1 & -4.6 & -4.1 & -4.7 & -5.1 \\
\hline Gross government debt & 157 & 193 & 223 & 258 & 266 & 267 & 267 & 268 \\
\hline Real interest rate (\%) & 2.7 & 2.4 & 3.0 & 3.0 & 3.4 & 4.0 & 4.6 & 5.6 \\
\hline Total national saving & 26.4 & 23.2 & 22.4 & 21.8 & 22.2 & 20.1 & 18.7 & 19.2 \\
\hline Total investment & 23.1 & 19.8 & 20.6 & 22.0 & 23.2 & 19.0 & 19.5 & 18.3 \\
\hline Current balance & 3.3 & 3.6 & 1.9 & 0.0 & -0.9 & 1.2 & -0.7 & 0.9 \\
\hline \multicolumn{9}{|l|}{ Euro Area } \\
\hline Potential real GDP growth (\%) & 1.9 & 1.0 & 1.3 & 1.9 & 1.6 & 1.3 & 1.3 & 1.3 \\
\hline Fiscal balance & -2.0 & -6.3 & -2.0 & -2.0 & -2.2 & -2.0 & -2.0 & -2.0 \\
\hline Gross government debt & 76 & 93 & 100 & 96 & 96 & 97 & 97 & 97 \\
\hline Real interest rate (\%) & 2.3 & 2.3 & 3.3 & 3.0 & 2.6 & 3.0 & 3.3 & 4.0 \\
\hline Total national saving & 21.5 & 19.3 & 20.4 & 17.4 & 14.6 & 12.4 & 12.0 & 12.6 \\
\hline Total investment & 21.3 & 19.3 & 18.9 & 20.0 & 18.9 & 15.6 & 14.6 & 13.2 \\
\hline Current balance & 0.3 & 0.4 & 1.5 & -2.5 & -4.3 & -3.2 & -2.5 & -0.5 \\
\hline \multicolumn{9}{|l|}{ OECD Total } \\
\hline Potential real GDP growth (\%) & & 1.6 & 2.0 & 2.3 & 2.2 & 1.8 & 1.8 & 1.7 \\
\hline Fiscal balance & -2.1 & -7.8 & -4.4 & -3.0 & -2.8 & -2.6 & -2.6 & -2.6 \\
\hline Gross government debt & 74 & 99 & 109 & 112 & 113 & 113 & 113 & 114 \\
\hline Real interest rate (\%) & 2.5 & 1.9 & 2.3 & 3.2 & 3.1 & 3.7 & 4.0 & 4.6 \\
\hline Total national saving & 19.8 & 18.0 & 18.8 & 17.3 & 15.5 & 14.0 & 13.5 & 13.3 \\
\hline Total investment & 21.0 & 18.6 & 19.5 & 19.2 & 18.6 & 15.7 & 14.5 & 13.1 \\
\hline Current balance & -1.2 & -0.6 & -0.8 & -2.1 & -3.3 & -1.9 & -1.2 & -0.1 \\
\hline \multicolumn{9}{|l|}{ China } \\
\hline Potential real GDP growth (\%) & 10.0 & 10.2 & 9.5 & 6.8 & 4.0 & 3.1 & 1.6 & 1.2 \\
\hline Total national saving & 44.6 & 51.8 & 50.1 & 42.9 & 33.2 & 19.6 & 16.4 & 10.1 \\
\hline Total investment & 40.1 & 47.8 & 48.3 & 38.6 & 27.5 & 21.8 & 15.6 & 13.1 \\
\hline Current balance & 4.6 & 4.0 & 1.7 & 4.3 & 5.7 & -2.2 & 0.7 & -3.0 \\
\hline \multicolumn{9}{|l|}{ India } \\
\hline Potential real GDP growth (\%) & 7.4 & 7.8 & 7.3 & 6.8 & 5.9 & 4.5 & 3.5 & 2.8 \\
\hline Total national saving & 29.6 & 31.8 & 28.3 & 26.1 & 22.8 & 18.8 & 16.6 & 13.6 \\
\hline Total investment & 27.1 & 31.1 & 28.4 & 27.3 & 24.4 & 20.0 & 17.0 & 14.5 \\
\hline Current balance & 0.0 & -3.2 & -2.9 & -4.1 & -4.6 & -4.1 & -3.4 & -3.8 \\
\hline \multicolumn{9}{|l|}{ Brazil } \\
\hline Potential real GDP growth (\%) & 3.1 & 4.2 & 4.5 & 4.1 & 3.5 & 2.4 & 1.8 & 0.7 \\
\hline Total national saving & 16.1 & 17.5 & 16.7 & 16.5 & 14.7 & 12.5 & 9.1 & 6.1 \\
\hline Total investment & 16.4 & 19.5 & 20.3 & 18.7 & 16.9 & 13.3 & 11.5 & 8.8 \\
\hline Current balance & 0.7 & -2.2 & -3.2 & -2.5 & -2.6 & -1.2 & -2.8 & -3.1 \\
\hline \multicolumn{9}{|l|}{ Russia } \\
\hline Potential real GDP growth (\%) & 5.3 & 4.3 & 4.1 & 2.8 & 2.4 & 0.4 & 1.0 & 2.3 \\
\hline \multicolumn{9}{|l|}{ Potential real GDP growth (\%) } \\
\hline OECD & 2.3 & 1.6 & 2.0 & 2.3 & 2.2 & 1.8 & 1.8 & 1.7 \\
\hline non - OECD & 7.0 & 7.8 & 7.6 & 6.0 & 4.3 & 3.2 & 2.2 & 1.8 \\
\hline World & 3.5 & 3.6 & 4.0 & 3.9 & 3.2 & 2.6 & 2.0 & 1.7 \\
\hline \multicolumn{9}{|l|}{ Share of real world GDP in 2005 PPPs (\%) } \\
\hline United States & 26.3 & 23.2 & 22.1 & 19.9 & 17.8 & 16.7 & 16.4 & 16.3 \\
\hline Japan & 8.3 & 7.0 & 6.4 & 5.2 & 4.2 & 3.6 & 3.3 & 3.2 \\
\hline Euro Area & 20.2 & 17.4 & 16.0 & 14.0 & 11.7 & 10.2 & 9.3 & 8.8 \\
\hline OECD & 74.1 & 65.9 & 62.4 & 55.5 & 49.0 & 44.9 & 42.9 & 42.3 \\
\hline China & 10.3 & 16.2 & 18.7 & 24.1 & 27.9 & 29.6 & 29.3 & 27.8 \\
\hline India & 4.8 & 6.4 & 7.1 & 8.5 & 11.1 & 13.8 & 16.2 & 18.2 \\
\hline Brazil & 3.3 & 3.5 & 3.5 & 3.5 & 3.6 & 3.6 & 3.5 & 3.3 \\
\hline Russia & 3.4 & 3.6 & 3.6 & 3.5 & 3.2 & 2.8 & 2.3 & 2.3 \\
\hline non-OECD & 25.9 & 34.1 & 37.6 & 44.5 & 51.0 & 55.1 & 57.1 & 57.7 \\
\hline
\end{tabular}




\subsubsection{The global saving rate will decline over the long run and be increasingly driven by China and India}

44. In the short term, most OECD countries face a cyclical fall in private saving rates as output gaps close. Further downward pressure on private saving rates then comes from ageing populations (Figure 16). ${ }^{29}$ Demographic developments (combining the effect of changes in old-age and youth dependency ratios as well life expectancy) are estimated to reduce the private saving rate of the median OECD country by about 5 percentage points by 2060. Much larger effects of 10-12 percentage points are projected for Korea, Portugal and Mexico and 8 percentage points for Chile, Israel and Spain. On the other hand, the demographic effect on private saving is somewhat below the OECD median for many of the largest OECD countries including France, Germany, United Kingdom and the United States. Increases in OECD public saving, required to stabilise general government debt, offset much of the fall in private saving at least until the mid-2020s, particularly in Japan and the United States, so it is only beyond then that there is a clear fall in the total (public plus private) OECD saving rate.

Figure 16. Saving rates are projected to decline

A: OECD private and public saving rates $(\% \text { of GDP })^{1}$

B: Total saving rates $(\%$ of GDP)
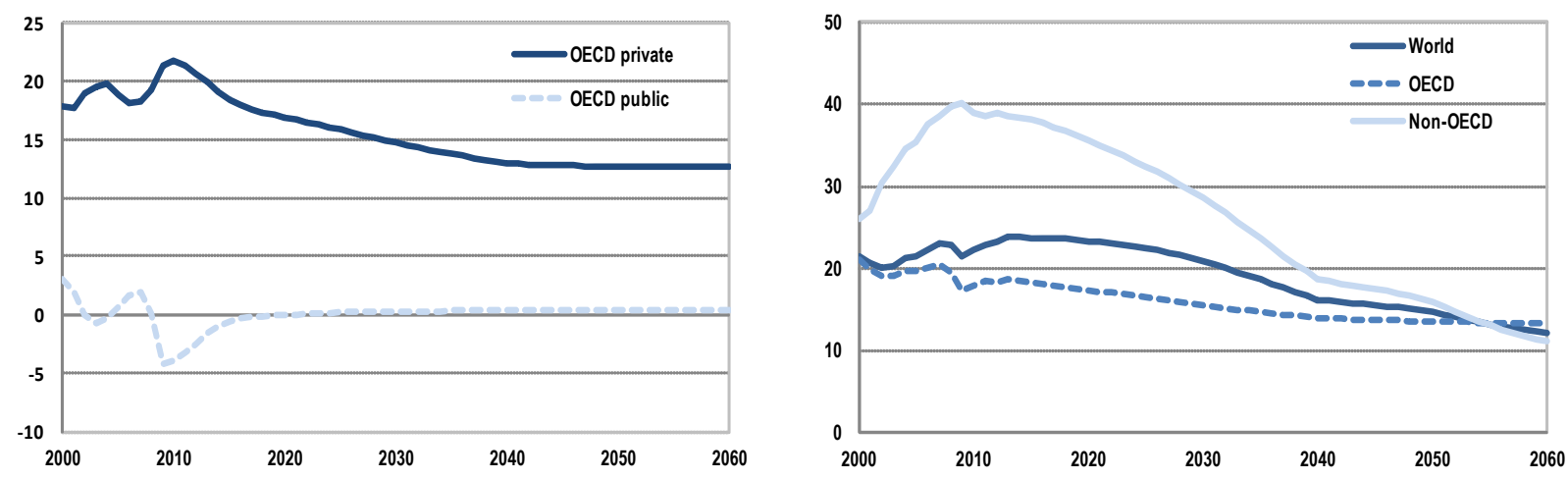

1. The disaggregation of total savings between public and private savings is not available for all OECD countries and so they do not sum exactly to total OECD savings.

45. Among the largest non-OECD economies, projected demographic influences on saving are even more heterogeneous, with two extreme and important cases being India and China. For India, the effect of falling youth dependency rates offsets much of the effect on saving from moderate increases in the old age dependency ratio, so that the overall demographic effect on saving is small. In contrast, for China, a legacy of the 'one-child policy' is that old age dependency rates are projected to rise more steeply than even in most OECD countries, with little change in youth dependency rates. Overall, this implies a very large fall in the Chinese saving rate of around 40 percentage points of GDP to 2060, about half of which is demographically-induced. On top of these demographic influences, there are other downward effects on saving rates in all emerging economies which are assumed to be phased in gradually by 2040 or 2060. A

29. A note of caution is warranted in using old-age dependency ratios based on fixed age groups when projecting saving rates, given that changes in life expectancy and retirement ages are also expected in future decades. For the purposes of sensitivity analysis, an alternative approach was tried using a rolling definition of the old-age dependency ratio for which the upper age limit was increased in line with the assumption about the extension of working lives. However, this approach eliminated virtually any demographically-induced fall in saving rates and was judged too extreme. Instead, a compromise approach, adopted for the projections reported here, was to incorporate an estimated positive effect from increasing longevity on saving, based on Li et al. (2007), which acts to partially offset the negative effect of rising old-age dependency rates. 
gradual improvement in social safety nets to 2040, through an increase in public spending on social protection of four percentage points of GDP to a level of provision similar to the average OECD country, reduces saving rates by 7-8 percentage points of GDP. A gradual catch-up in the availability of credit to 2060 , to levels of provision currently available in most OECD countries, typically reduces saving rates by 3-4 percentage points. When including all influences together, total saving rates in the non-OECD fall by between 5 and 40 percentage points between 2013 and 2060 (unweighted average of 19 percentage points).

46. Paradoxically, while saving rates are falling in most countries, the global saving rate remains near historical levels until the early 2030s as the share of high saving countries in global output rises sharply (Figure 17). Particularly striking is the growing importance of China and India in accounting for global saving, rising from just under $30 \%$ in 2010 to nearly $50 \%$ by 2030 . Beyond 2030 , the global saving rate starts falling more clearly as high-saving non-OECD countries grow slower and save less at the same time. However, large uncertainty surrounds projections for saving rates in emerging economies. Firstly, the panel equations used to project saving have generally under-estimated the rise in saving, notably in China and India, over the past decade, which in turn suggests that there are other, perhaps country-specific, factors at work and/or that saving rates have overshot levels supported by fundamentals. Secondly, future saving rates in emerging economies could be subject to additional change if, for example, the provision of more comprehensive social safety nets, or access to easier credit, were to be introduced more quickly than assumed in the baseline scenario. The impact of some of these factors is explored in the next section.

Figure 17. Emerging countries will account for a larger share in global saving

A : National saving rates (\% of GDP)

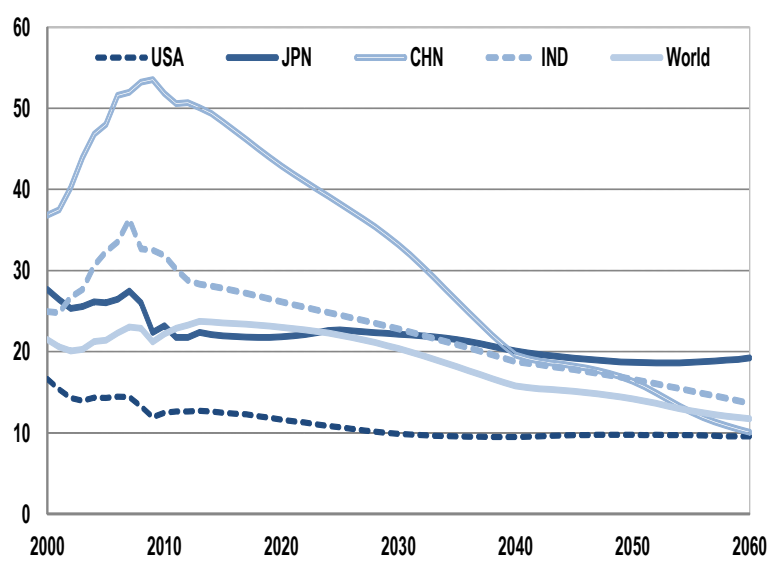

B : Shares in global savings (\%)

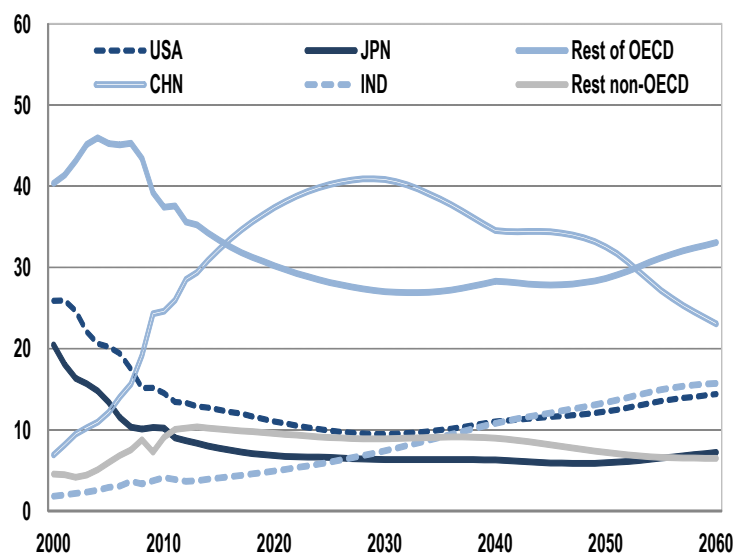

\subsubsection{Global current account imbalances will build up}

47. Global current account imbalances are projected to widen up until the late 2020s, and then narrow again (Figure 18). In the short term, a widening of global current account imbalances is mostly a cyclical response as output gaps close, since those countries that had been running the largest deficits prior to the crisis (most obviously the United States) have typically experienced sharper downturns than those that had been running surpluses (most obviously China but also Germany and to a lesser extent Japan). Over the longer term, the negative effect of ageing populations on saving is the dominant effect, leading to reduced current account balances in most OECD countries, although Germany, Netherlands and some Nordic countries continue to run surpluses. A few countries -- Italy, Greece and Portugal -- are projected to run persistent very large current account deficits of 10-15\% of GDP. This suggests that some further policy response would be needed, which in most of these cases could include additional fiscal consolidation as 
government debt remains high in these countries. ${ }^{30}$ China is projected to have a widening current account surplus up to the late 2020 s as the investment rate falls more rapidly than the saving rate due to slowing potential growth. The current account surplus of oil exporters is projected to rise only slightly to 2030 reflecting modest increases in real oil prices set against the tendency for oil exporters to gradually run down current account surpluses. Overall, the scale of current account imbalances (normalised on world GDP) is projected to approach the pre-crisis (2007) peak by 2025-2030.

Figure 18. Global imbalances are projected to rise over the next two decades

Current account balances as a share of world GDP (\%)

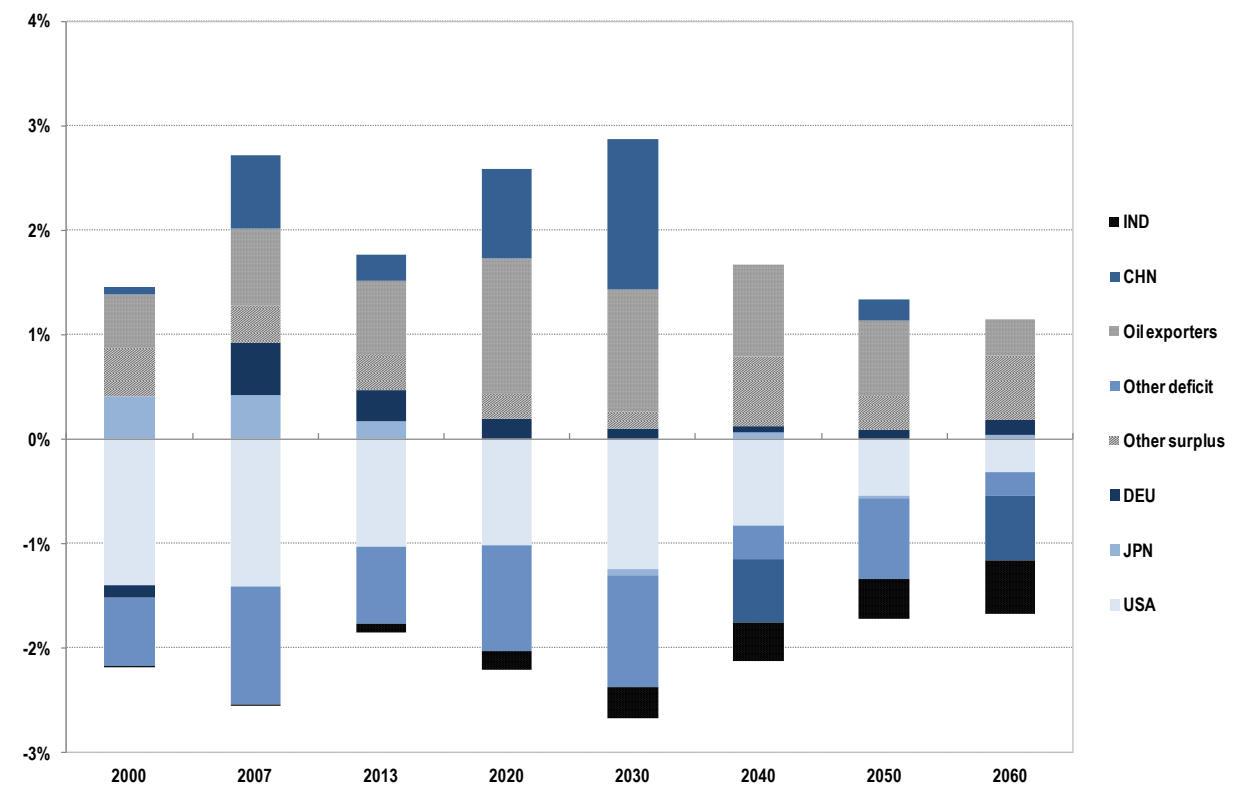

48. Beyond 2030, the imbalances of China, the United States and the oil exporters are all expected to decline, bringing some relief to overall global current account imbalances. In the case of the United States, the current account deficit falls mostly because demographic effects are projected to have a smaller negative impact on saving than in many other countries (and because the United States then accounts for a smaller share of world GDP). China's large current account surplus begins to decline in the 2030s as the old-age dependency ratio rises more rapidly, lowering the saving rate more quickly. The decline in the current account surplus of the oil exporting countries mostly reflects the technical assumption of only $1 \%$ per annum increase in real oil prices after 2030, combined with an estimated response of the overall current account surplus to any oil surplus which diminishes over time.

\subsubsection{There will be upward pressure on interest rates}

49. Real interest rates in most OECD economies, evaluated against the growth rate of potential output, are projected to be much higher than experienced over the last decade (Figure 19), which suggests a much less favourable environment for countries running high debt-to-GDP ratios. The reasons for the projected rise in real interest rates compared with the pre-crisis 2000s are threefold. First, unusually low policy rates since the onset of the crisis have dragged down long-term interest rates, and the future normalisation of short-term interest rates as output gaps close will reverse this: Turner and Spinelli (2011)

30. It should be noted, however, that the baseline projection does not build in any recently agreed fiscal measures, in particular it does not incorporate the effect of recently agreed programmes of fiscal consolidation in euro area countries that have been under financial market pressure. 
estimate that this will increase the long-term interest rate-growth differential by 1 to $1 \frac{1 / 4}{4}$ percentage points for a typical OECD country. Second, higher government indebtedness is projected to increase fiscal risk premia: the number of OECD countries exceeding the 75\% debt-to-GDP threshold at which fiscal risk premia begin to increase is projected to rise from six in the pre-crisis period to seventeen. Among these countries, Japan is treated as an exception (Box 7). Given the large share of government debt that has historically been financed domestically (Hoshi and Ito, 2012), the effect of government debt on the fiscal risk premium is assumed to be more modest. How far this should be projected forward is debatable if the external account is weakening, however. Finally, and more speculatively, the decline in the global saving rate beyond 2030, which is in large part driven by demographic developments, especially in China, as well as the effects of advances in social protection and credit availability in non-OECD countries, may lead to an $e x$ ante global savings shortage. This could place upward pressures on real interest rates; the baseline projections reported here imply an increase of about $1 \frac{1 / 2}{2}$ percentage points in global real interest rates between 2030 and 2060, which is of the same order of magnitude, but opposite in sign, to the negative effect which the "global savings glut" (Bernanke, 2005) is estimated to have had on OECD interest rates during the pre-crisis 2000s, according to Turner and Spinelli (2011).

Figure 19. The interest rate-growth differential is projected to rise among OECD countries Percentage points

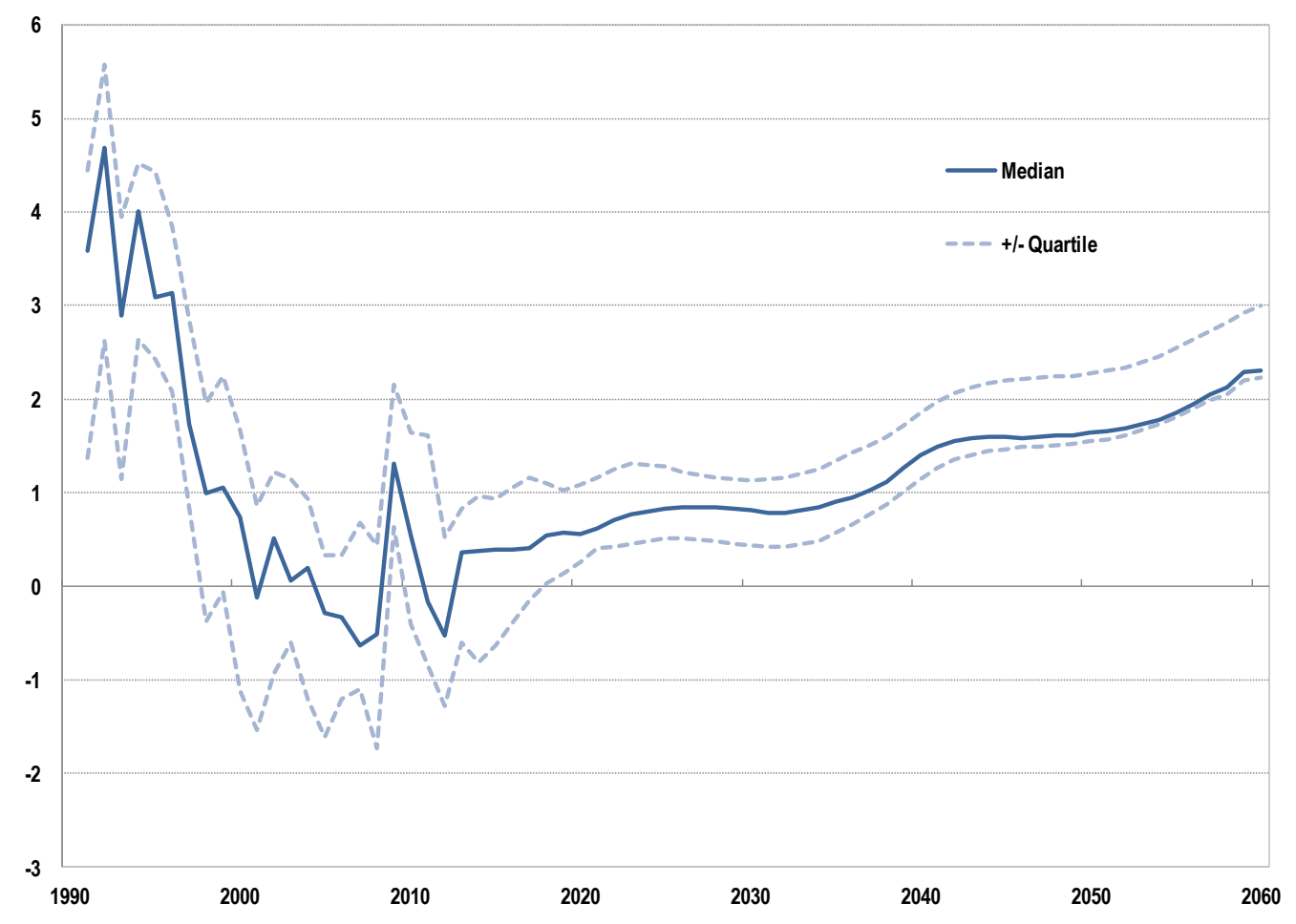

Note: Shows the median interest rate-growth differential for a sample of 23 OECD countries for which there is a consistent historical data set. Interest rates are those on 10-year government bonds and the growth rate is the growth rate of estimated nominal potential GDP. 
ECO/WKP(2012)77

\section{Box 7. Interest rates and fiscal consolidation in Japan}

Japan is treated as an exception in the baseline scenario by assuming that the magnitude of its fiscal risk premium, in terms of the increase in interest rates per percentage point of debt beyond certain thresholds, is only one quarter that of other OECD countries. Nevertheless, the real interest rate in Japan rises to almost $6 \%$ by 2060 and gross government debt eventually stabilises at around $265 \%$ of GDP. One reason why the risk premium may be low in Japan is the high proportion of government debt which is financed from domestic sources. This has been possible thanks to a high private saving rate and to a current account that has been in surplus since the early 1980 s, so that for the past three decades Japan has not had to rely on external sources to finance its government deficits. However, in the baseline scenario, Japan's current account is expected to move into deficit in the 2020s, mostly because of a decline in the private saving rate due to population ageing. When this occurs, and the government needs to seek foreign sources of financing, foreigners may well ask for a more "normal" fiscal risk premium, which could quickly generate an unsustainable and unstable situation.

To illustrate this possibility, an alternative scenario was run where the fiscal risk premium in Japan starts rising from one-quarter of the normal OECD premium in 2025 to the full OECD premium by the end of the projection period. In this scenario, the real interest rate in Japan rises much more rapidly starting in 2025 to reach more than $10 \%$ by 2060. As a result, Japan must undertake nearly 9 percentage points of GDP more in fiscal consolidation between 2025 and 2060 to keep the debt ratio from exploding, on top of an already huge fiscal consolidation of $141 / 2$ percentage points of GDP between 2013 and 2060 in the baseline scenario. Finally, higher real interest rates depress investment and potential output growth. Between 2025 and 2060, potential output growth averages 0.2 percentage point less than in the baseline scenario and the level of potential output is $7 \frac{1}{2}$ per cent lower by 2060 as a result of this effect.

Real interest rate in Japan

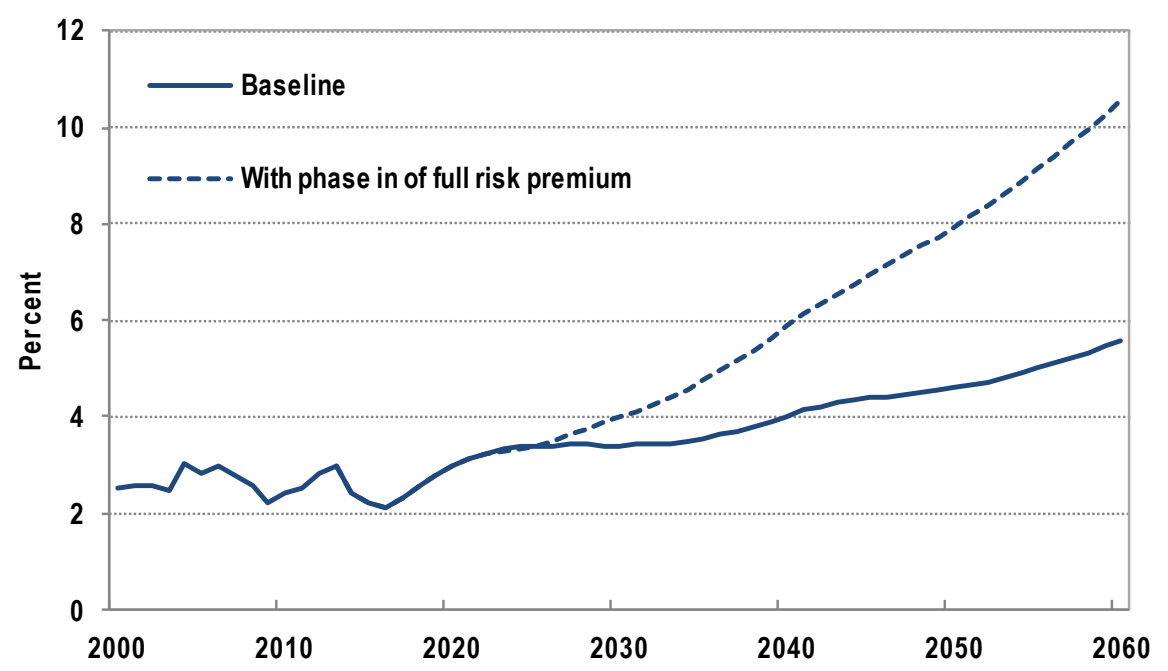

\section{Bold macro and structural policies can enhance growth and reduce global imbalances}

\subsection{Ambitious fiscal policies can reduce indebtedness and global imbalances}

50. High government indebtedness in many OECD countries, coupled with the possibility of higher interest rates than have recently been experienced, suggests a need for more ambitious fiscal consolidation. In an alternative scenario summarised in Table 2, OECD countries are assumed to undertake more rapid fiscal consolidation, improving their fiscal balance by up to 1 percentage point of GDP each year for as 
long as it takes to target a gross debt ratio of $60 \%,{ }^{31}$ unless the debt ratio is already projected to be lower than $60 \%$ in the baseline in which case no further consolidation is assumed. An important qualification to this scenario is that no explicit account is taken of the short-term adverse effect of fiscal consolidation on demand. Rather the focus is on the medium- and long-term effects on potential output.

51. Faster OECD-wide fiscal consolidation lowers real interest rates as fiscal risk premia decrease along with public indebtedness, boosting investment and potential output growth. Average gross government debt in the OECD is lower by more than 50 percentage points of GDP by 2060 (Figure 20, Panel A). Not only does OECD-wide public indebtedness go down substantially, but, perhaps more importantly, from 10 OECD countries with debt ratios in excess of $100 \%$ in 2013 , none remain above this level by 2040 (Figure 20, Panel B). Fiscal consolidation has two distinct effects on interest rates: firstly, lower government indebtedness lowers that country's fiscal risk premia; secondly, it also increases global savings and so puts downward pressure on global interest rates. The second effect is obviously more important when larger rather than smaller countries undertake substantial consolidation, as is the case in this alternative scenario because the United States, Japan, Italy, the United Kingdom and France are among the countries with the highest levels of debt in the baseline. The combined inverse snowball effect eases debt reduction: consolidation both reduces national risk premia and global interest rates making it easier to reach the $60 \%$ debt level. Overall, the average OECD long-term real interest rate is about 11/4 percentage points lower in this alternative scenario than in the baseline (Figure 20, Panel C), with a much larger difference for countries undertaking the most consolidation. OECD potential output growth is noticeably higher for a period as lower real interest rates reduce the cost of capital thereby increasing capital deepening (Figure 20, Panel D). The level of potential OECD output increases by more than $3 \%$ by 2060 and by much more in those countries where indebtedness falls most, for example potential output in Greece is boosted by more than $10 \%$.

31. Gradual fiscal consolidation paths consistent with debt stabilisation at the target are obtained using a fiscal rule derived by Rawdanowicz (2012). The fiscal rule accounts for the current gross debt-to-GDP ratio, its target, the current level of government assets, the current fiscal balance, nominal GDP growth relative to potential in the current year as well as projected nominal GDP growth 10 years ahead (the rule is forwardlooking). There is also a parameter to account for the size of automatic stabilisers. In years where the rule would call for fiscal consolidation greater than a certain cap (here 1\% of GDP) the cap is applied instead. 
ECO/WKP(2012)77

Table 2. Summary of the long-term projections, assuming more ambitious fiscal consolidation

$\%$ of GDP unless otherwise stated

\begin{tabular}{|c|c|c|c|c|c|c|c|c|}
\hline & Avg 2000-07 & 2010 & 2013 & 2020 & 2030 & 2040 & 2050 & 2060 \\
\hline \multicolumn{9}{|l|}{ United States } \\
\hline Potential real GDP growth (\%) & 2.6 & 1.7 & 2.1 & 2.5 & 2.5 & 2.1 & 1.9 & 1.8 \\
\hline Fiscal balance & -2.6 & -10.7 & -6.5 & 2.4 & -0.9 & -1.5 & -1.4 & -1.4 \\
\hline Gross government debt & 62 & 98 & 111 & 90 & 62 & 60 & 60 & 60 \\
\hline Real interest rate (\%) & 2.4 & 1.7 & 1.4 & 2.6 & 2.4 & 2.9 & 3.0 & 3.4 \\
\hline Total national saving & 14.7 & 12.5 & 12.7 & 15.7 & 11.9 & 11.0 & 11.1 & 10.9 \\
\hline Total investment & 19.7 & 15.8 & 17.0 & 18.1 & 18.2 & 15.0 & 13.8 & 12.3 \\
\hline Current balance & -4.9 & -3.2 & -4.3 & -2.4 & -6.3 & -4.0 & -2.7 & -1.4 \\
\hline \multicolumn{9}{|l|}{ Japan } \\
\hline Potential real GDP growth (\%) & 0.7 & 0.6 & 0.8 & 1.4 & 1.8 & 1.3 & 1.6 & 1.7 \\
\hline Fiscal balance & -5.4 & -8.4 & -10.1 & 0.4 & 10.9 & 2.1 & 0.6 & 0.5 \\
\hline Gross government debt & 157 & 193 & 223 & 229 & 122 & 66 & 60 & 60 \\
\hline Real interest rate (\%) & 2.7 & 2.4 & 3.0 & 2.4 & 1.8 & 2.1 & 2.4 & 3.2 \\
\hline Total national saving & 26.4 & 23.2 & 22.4 & 26.4 & 31.7 & 23.9 & 21.9 & 22.6 \\
\hline Total investment & 23.1 & 19.8 & 20.6 & 25.3 & 30.7 & 23.4 & 22.7 & 20.7 \\
\hline Current balance & 3.3 & 3.6 & 1.9 & 1.2 & 1.1 & 0.5 & -0.7 & 1.9 \\
\hline \multicolumn{9}{|l|}{ Euro Area } \\
\hline Potential real GDP growth (\%) & 1.9 & 1.0 & 1.3 & 2.1 & 1.7 & 1.3 & 1.3 & 1.3 \\
\hline Fiscal balance & -2.0 & -6.3 & -2.0 & 1.9 & -0.4 & -0.7 & -0.8 & -0.8 \\
\hline Gross government debt & 76 & 93 & 100 & 77 & 61 & 60 & 60 & 60 \\
\hline Real interest rate (\%) & 2.3 & 2.3 & 3.3 & 2.4 & 1.7 & 2.1 & 2.3 & 2.8 \\
\hline Total national saving & 21.5 & 19.3 & 20.4 & 19.8 & 15.7 & 13.1 & 12.7 & 13.2 \\
\hline Total investment & 21.3 & 19.3 & 18.9 & 22.3 & 20.9 & 16.6 & 15.6 & 14.2 \\
\hline Current balance & 0.3 & 0.4 & 1.5 & -2.3 & -5.2 & -3.5 & -2.8 & -0.7 \\
\hline \multicolumn{9}{|l|}{ OECD Total } \\
\hline Potential real GDP growth (\%) & & 1.6 & 2.0 & 2.5 & 2.3 & 1.9 & 1.8 & 1.7 \\
\hline Fiscal balance & -2.1 & -7.8 & -4.4 & 1.8 & 0.6 & -0.5 & -0.6 & -0.5 \\
\hline Gross government debt & 74 & 99 & 109 & 92 & 64 & 58 & 57 & 57 \\
\hline Real interest rate (\%) & 2.5 & 1.9 & 2.3 & 2.5 & 2.1 & 2.5 & 2.7 & 3.2 \\
\hline Total national saving & 19.8 & 18.0 & 18.8 & 20.1 & 17.5 & 15.0 & 14.3 & 13.9 \\
\hline Total investment & 21.0 & 18.6 & 19.5 & 21.1 & 20.8 & 16.8 & 15.6 & 14.1 \\
\hline Current balance & -1.2 & -0.6 & -0.8 & -1.2 & -3.5 & -2.0 & -1.5 & -0.4 \\
\hline \multicolumn{9}{|l|}{ China } \\
\hline Potential real GDP growth (\%) & 10.0 & 10.2 & 9.5 & 6.9 & 4.0 & 3.1 & 1.6 & 1.2 \\
\hline Total national saving & 44.6 & 51.8 & 50.1 & 42.9 & 33.2 & 19.6 & 16.4 & 10.1 \\
\hline Total investment & 40.1 & 47.8 & 48.3 & 39.6 & 28.3 & 22.2 & 16.1 & 13.6 \\
\hline Current balance & 4.6 & 4.0 & 1.7 & 3.3 & 4.9 & -2.6 & 0.2 & -3.5 \\
\hline \multicolumn{9}{|l|}{ India } \\
\hline Potential real GDP growth (\%) & 7.4 & 7.8 & 7.3 & 6.9 & 5.9 & 4.5 & 3.5 & 2.8 \\
\hline Total national saving & 29.6 & 31.8 & 28.3 & 30.4 & 27.0 & 23.0 & 20.8 & 17.8 \\
\hline Total investment & 27.1 & 31.1 & 28.4 & 27.8 & 24.9 & 20.2 & 17.3 & 14.9 \\
\hline Current balance & 0.0 & -3.2 & -2.9 & -0.4 & -0.8 & -0.2 & 0.5 & 0.0 \\
\hline \multicolumn{9}{|l|}{ Brazil } \\
\hline Potential real GDP growth (\%) & 3.1 & 4.2 & 4.5 & 4.2 & 3.6 & 2.4 & 1.8 & 0.7 \\
\hline Total national saving & 16.1 & 17.5 & 16.7 & 16.5 & 14.7 & 12.5 & 9.1 & 6.1 \\
\hline Total investment & 16.4 & 19.5 & 20.3 & 19.3 & 17.3 & 13.5 & 11.8 & 9.1 \\
\hline Current balance & 0.7 & -2.2 & -3.2 & -3.0 & -3.0 & -1.4 & -3.1 & -3.4 \\
\hline \multicolumn{9}{|l|}{ Russia } \\
\hline Potential real GDP growth (\%) & 5.3 & 4.3 & 4.1 & 2.9 & 2.4 & 0.4 & 1.0 & 2.3 \\
\hline \multicolumn{9}{|l|}{ Potential real GDP growth (\%) } \\
\hline OECD & 2.3 & 1.6 & 2.0 & 2.5 & 2.3 & 1.9 & 1.8 & 1.7 \\
\hline non - OECD & 7.0 & 7.8 & 7.6 & 6.1 & 4.3 & 3.2 & 2.2 & 1.8 \\
\hline World & 3.5 & 3.6 & 4.0 & 4.0 & 3.3 & 2.6 & 2.0 & 1.7 \\
\hline \multicolumn{9}{|l|}{ Share of real world GDP in 2005 PPPs (\%) } \\
\hline United States & 26.3 & 23.2 & 22.1 & 19.9 & 18.0 & 17.0 & 16.6 & 16.6 \\
\hline Japan & 8.3 & 7.0 & 6.4 & 4.8 & 4.0 & 3.5 & 3.2 & 3.1 \\
\hline Euro Area & 20.2 & 17.4 & 16.0 & 14.0 & 11.9 & 10.3 & 9.4 & 8.9 \\
\hline OECD & 74.1 & 65.9 & 62.4 & 55.6 & 49.4 & 45.4 & 43.5 & 42.8 \\
\hline China & 10.3 & 16.2 & 18.7 & 24.1 & 27.7 & 29.3 & 29.1 & 27.6 \\
\hline India & 4.8 & 6.4 & 7.1 & 8.5 & 11.0 & 13.6 & 16.0 & 18.0 \\
\hline Brazil & 3.3 & 3.5 & 3.5 & 3.5 & 3.6 & 3.6 & 3.5 & 3.3 \\
\hline Russia & 3.4 & 3.6 & 3.6 & 3.5 & 3.2 & 2.7 & 2.3 & 2.3 \\
\hline non-OECD & 25.9 & 34.1 & 37.6 & 44.4 & 50.6 & 54.6 & 56.5 & 57.2 \\
\hline
\end{tabular}


Figure 20. More ambitious fiscal consolidation boosts potential growth

\section{A : OECD gross government debt, \% of GDP}

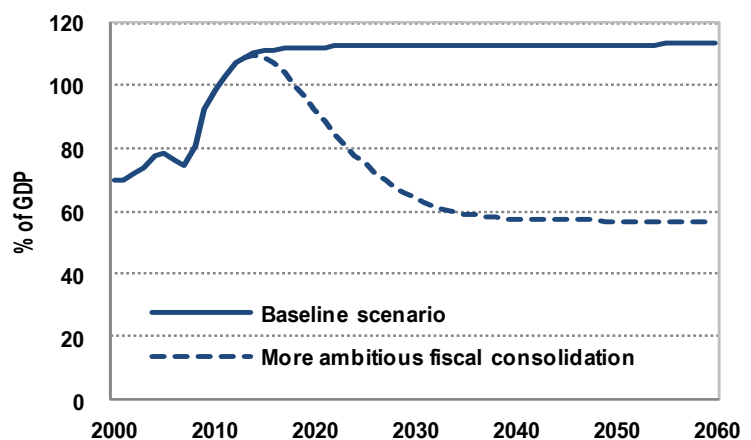

C : OECD real long-term interest rate

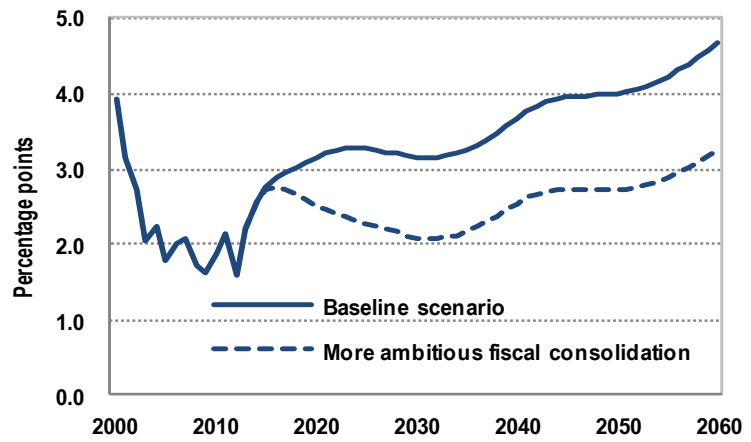

$B$ : Number of OECD countries with gross debt greater than $100 \%$ of GDP

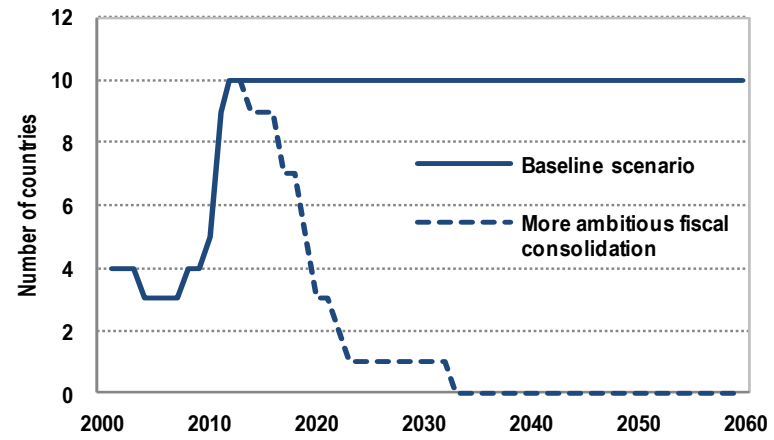

D : Potential output growth, OECD average

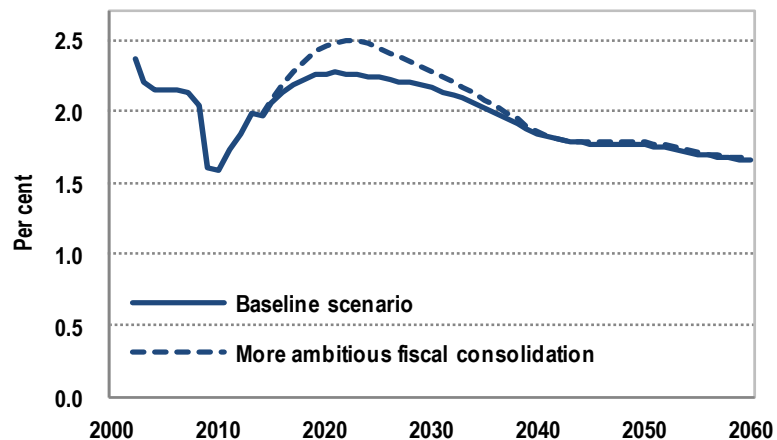

\subsubsection{More ambitious fiscal consolidation also reduces global imbalances}

52. More ambitious OECD-wide fiscal consolidation has the additional benefit of reducing global imbalances through a reduction in current account deficits in OECD countries due to higher public saving. The peak effect on total global imbalances -- measured as half the sum of individual current balances in absolute value as a share of world GDP -- is achieved in the late 2010 s when they are approximately $1 / 4$ of a percentage point of world GDP lower than in the baseline scenario, implying a reduction in total global imbalances by about one-tenth (Figure 21). 
Figure 21. Policy action can reduce global imbalances

Sum of current account balances in absolute value divided by 2

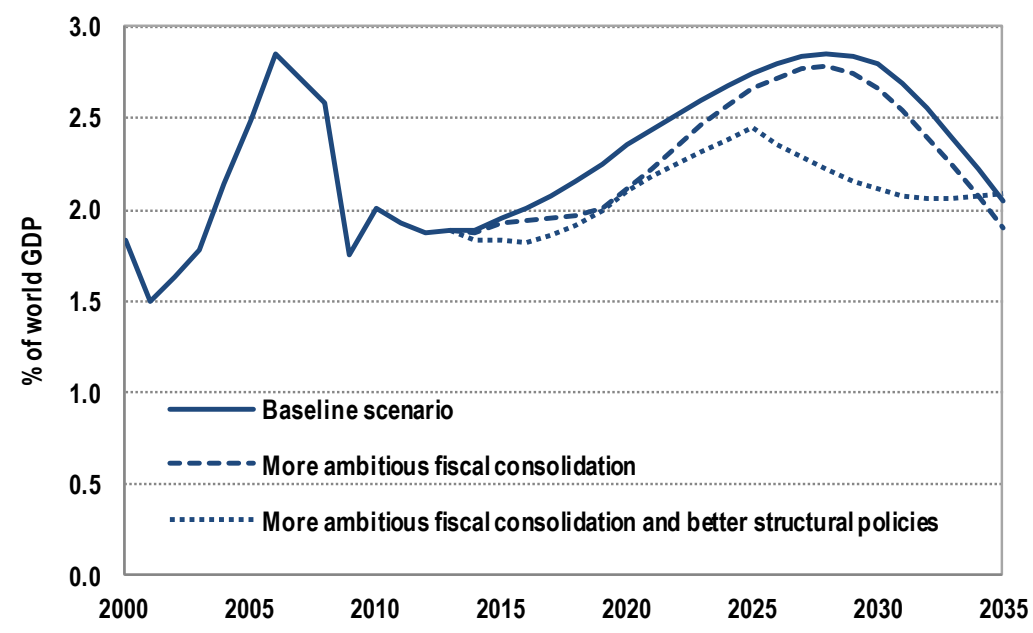

53. As in the case of public indebtedness, perhaps as important as reducing average global imbalances is that the number of extreme cases is also lowered, that is, countries with very high current account deficits. These include countries that have been badly affected by the global financial and economic crisis and that suffer from both high public indebtedness and a lack of competitiveness. Such countries include Greece, Ireland, Iceland, Italy and Portugal that in the baseline scenario are all projected to have large current account deficits as well as gross government debt in excess of 100\% of GDP by the mid-2020s. With additional fiscal consolidation, ${ }^{32}$ the projected current account balance of each of these countries is significantly improved; with peak improvements over the next decade of $2 \frac{1}{4}$ to $4 \frac{1}{2}$ percentage points of GDP.

\subsection{Deep structural reforms can raise potential GDP}

\subsubsection{Product market liberalisation would speed up convergence}

54. The scenario of relatively slow convergence of product market policies towards average OECD levels of regulation may not be realistic given the push for structural reform currently exerted in the context of the G20 mutual assessment process. If more rapid liberalisation in product markets is achieved, productivity gaps may close faster. For instance, assuming that the target for product market regulations is the average level of regulations in the five "best practice" countries in 2011 (i.e. the United States, the United Kingdom, Ireland, Canada and the Netherlands), average MFP growth would increase by 0.2 percentage points annually relative to the baseline over the period 2011-2060. Relative to the baseline, this would increase GDP by an average of $10 \%$ in 2060, the impact being greater in countries with relatively stringent regulations, such as China, Turkey, Slovenia and Greece. ${ }^{33}$

32. The extent of fiscal consolidation which is assumed here is consistent with a stylised scenario and is not intended to correspond with the programmes of fiscal consolidation which have recently been agreed in those euro area countries under financial stress.

33. Similarly, if greater trade liberalisation were achieved, productivity would be enhanced via the impact on openness and, in turn, the diffusion of technology. For instance, if remaining trade barriers were to be lowered to the current average level observed in the five "best practice" countries, productivity growth would increase relative to the baseline, albeit much more moderately than in the case of accelerated product market reforms, with GDP gaining on average $0.4 \%$ in 2060 relative to baseline. Indeed, the gain 


\subsubsection{Labour market reforms can boost long-run GDP}

55. As in the case of product market policies, deeper labour market reforms than in the baseline can boost GDP via higher labour force participation rates. ${ }^{34}$ To examine this possibility, an alternative scenario is considered in which cross-country differences in active life expectancy are progressively eliminated, with the average duration of individual active life slowly converging in all countries towards the standard observed in Switzerland, one of the leading countries in terms of aggregate participation. Implementing the reforms needed to achieve the implied reduction in exit from the labour force at old-age would probably be easier in countries where the exit rate is currently high (e.g. France, Slovak Republic, Hungary) than in countries where the exit out from the labour force of older workers is already very low (e.g. Iceland and New Zealand).

56. Under this deeper labour market reform scenario, aggregate participation is projected to increase on average across OECD countries by 2.7 percentage points relative to the baseline, to reach around $62 \%$ in 2060 (Figure 22). The increase in participation would be particularly marked in Italy $(+13$ percentage points), Korea ( +9 points) and Hungary ( +6 points). In other countries, participation would moderately increase or decline by less than in the baseline scenario. As a result of this labour outcome, GDP would be close to $6 \%$ higher on average in 2060 as compared with the baseline. ${ }^{35}$

from reducing trade barriers is more limited as these already have been eased in emerging economies. Moreover, in the current model increases in trade openness only affect productivity indirectly via the effect of technology diffusion on the speed of catch-up and not via any direct effect of openness on MFP. Additionally, trade openness can speed up the convergence in average years of schooling (e.g. Bourguignon and Verdier, 2005). A simulation suggest that a country with a level of trade openness 20 percentage points above the OECD average would close its educational gap faster, resulting in a $0.5 \%$ increase in GDP per capita in 2060.

34. It should be noted that this stylised scenario does not take into account any ramifications on public budgets and interest rates from the labour reforms, which could be potentially significant.

35. In a few countries (Iceland, Sweden, Denmark and Estonia) participation is lower in the convergence scenario than in the baseline because the ratio of active life expectancy to life expectancy at birth is higher than the long-term target (Switzerland). Therefore, in the combined policy scenario (section 4.3), for these countries the baseline labour force projections is applied. 
Figure 22. Convergence in labour force participation

Labour force participation among $15+$ assuming convergence in the share of life time in activity, per cent

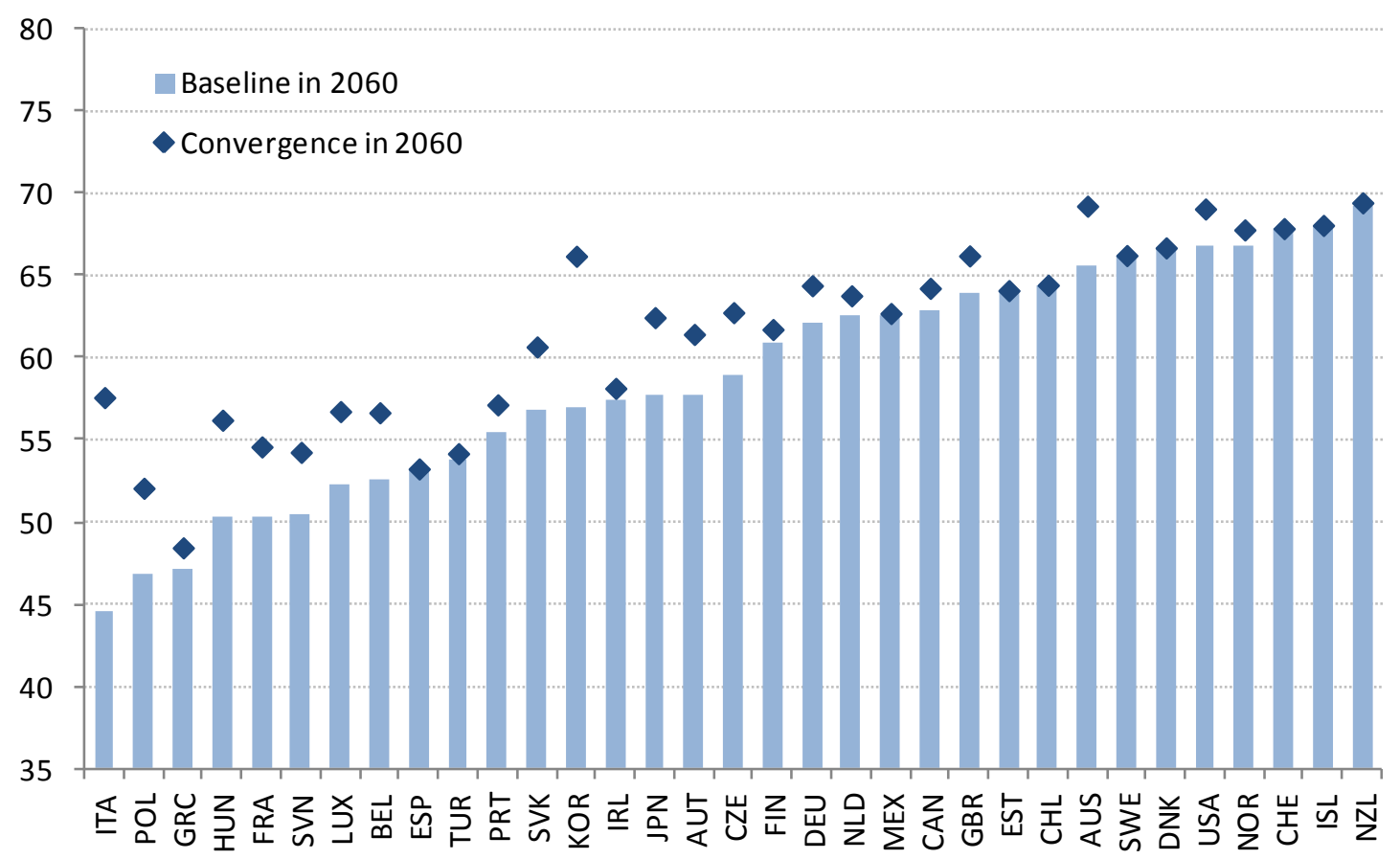

1. This chart only shows trends in labour force participation for OECD countries for which the cohort-analysis is performed.

\subsection{Ambitious fiscal consolidation and structural reforms can reduce imbalances and boost growth}

57. A final scenario combines more ambitious OECD fiscal consolidation policies with deeper structural reforms (Table 3). Structural policy reforms provide for a faster improvement in product market regulation, reductions in the tax wedge ${ }^{36}$ to lower trend unemployment (see Appendix 5) and higher labour force participation rates (see above). In addition, welfare and financial reforms in non-OECD countries are assumed to occur more quickly than in the baseline: whereas public spending on social protection increases by 4 percentage points of GDP by 2040 in the baseline, the increase is assumed to take place by 2025; similarly, the availability of credit (expressed as a share of GDP) is assumed to reach the same level in 2035 as was previously achieved in the baseline by 2060 .

58. The main macroeconomic impact of combined fiscal and structural reforms is to boost potential growth, with the level of 2060 potential output eventually raised in both the OECD and non-OECD countries, by about $11 \%$ and 17\%, respectively (Figure 23, Panel A). There are, however, large differences in the magnitude of this effect across countries. The effects are largest in countries where the scope for improvement to structural polices relative to best practice is greatest (Figure 23, Panel B). The effect of structural reforms on individual countries can be evaluated in two distinct ways; the first by evaluating structural reforms in each country in isolation from reforms in other countries, referred to as "national structural policies"; the second by combining the effects of structural reforms in a "combined scenario" in which all countries undertake reforms simultaneously. The latter effects are usually slightly reduced compared to the former, because when all countries undertake reforms simultaneously, faster global

36. This simulation relies on the simplifying assumption that the fiscal cost of the tax cut is financed by an increase in income tax revenues as well as from savings on unemployment benefits from greater participation in the labour market. 
growth pushes up global interest rates, partially offsetting the positive effect of structural reforms on GDP. There are a few exceptions, notably Greece and Japan, where the combined scenario generates larger GDP gains than national-only reforms because these countries are also assumed to be undertaking substantial fiscal consolidation, which lowers their interest rates. In the combined scenario, the largest gainers are Korea, Italy and Belgium, where there are large potential gains from raising labour force participation. Greece is also a large gainer because of its large potential for loosening product market regulations. On the other hand, countries such as Canada, Denmark, Iceland, and Netherlands appear to benefit less from structural reforms, but this is only because they are currently at, or close to, the best practice in respect of product market regulation or labour force participation.

Figure 23. Structural reforms and more ambitious fiscal consolidation raise GDP

A: Potential real GDP growth (\% pa)

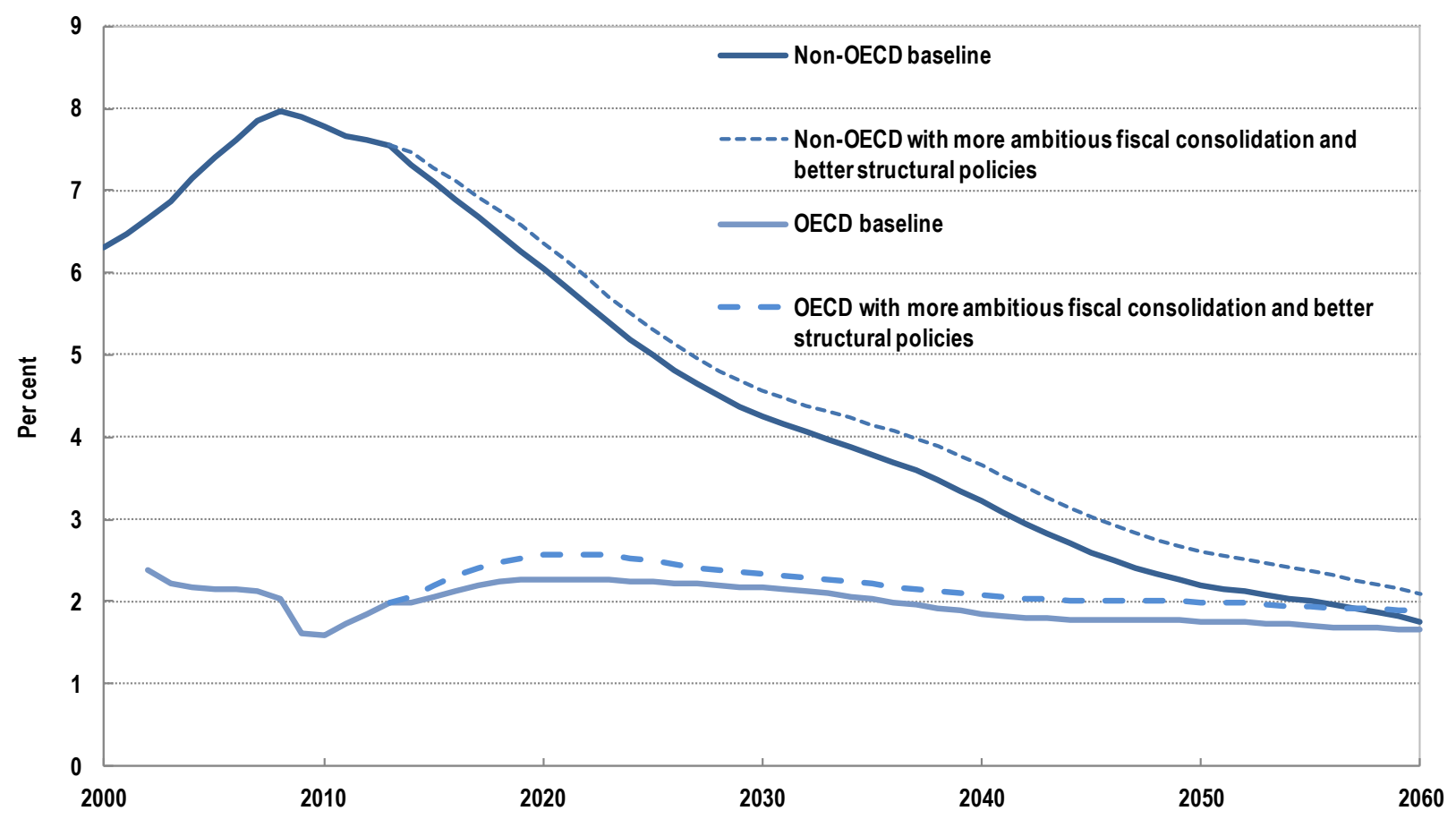


B: Differences in GDP levels in 2060 as compared with the baseline (\%)

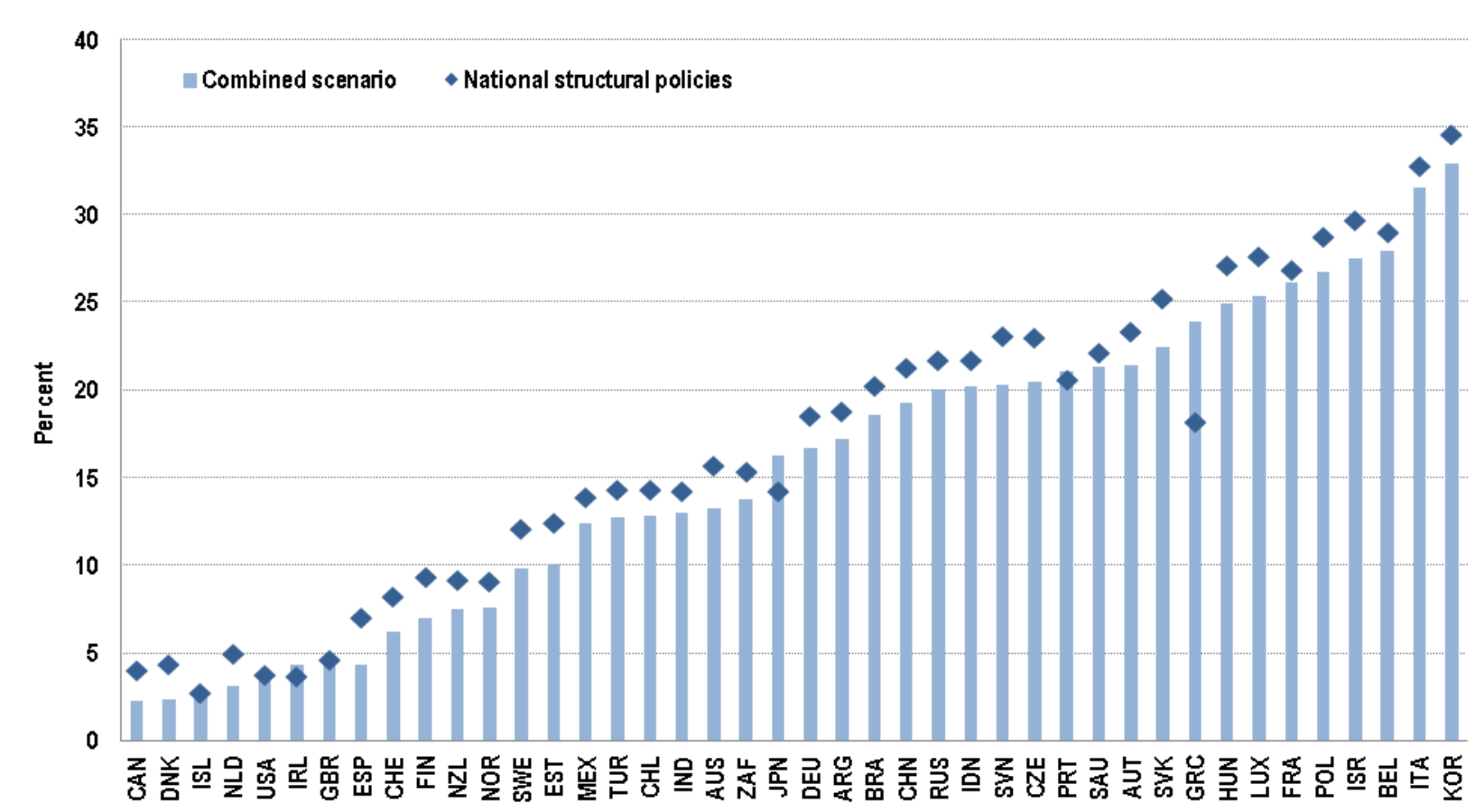

59. The effect of structural policy reforms, over and above the effect of more ambitious fiscal consolidation, implies a further improvement in global current account imbalances (Figure 21). The reduction in global imbalances due to better structural policies takes more time to build up than that due to fiscal consolidation and peaks a decade later in the late 2020s. The combined effect also peaks then when it amounts to a reduction in global imbalances of close to 0.7 percentage point of world GDP, or about a quarter of the total. This improvement comes about principally by lowering large current account surpluses in some non-OECD economies, especially China, because precautionary saving falls more rapidly as a consequence of more rapid implementation of welfare reforms. Structural policy reforms thus both substantially raise long-run GDP and contribute to lower global imbalances, although they do tend to put upward pressure on global real interest rates, both as a consequence of faster potential output growth rates, which raise investment, and because of lower savings in non-OECD economies from more rapid welfare and financial reforms. 
Table 3(a). Summary of scenario with more ambitious fiscal consolidation and structural reforms

$\%$ of GDP unless otherwise stated

\begin{tabular}{|c|c|c|c|c|c|c|c|c|}
\hline & Avg 2000-07 & 2010 & 2013 & 2020 & 2030 & 2040 & 2050 & 2060 \\
\hline \multicolumn{9}{|l|}{ United States } \\
\hline Potential real GDP growth (\%) & 2.6 & 1.7 & 2.1 & 2.5 & 2.4 & 2.1 & 2.0 & 1.9 \\
\hline Fiscal balance & -2.6 & -10.7 & -6.5 & 2.4 & -0.9 & -1.5 & -1.5 & -1.4 \\
\hline Gross government debt & 62 & 98 & 111 & 90 & 62 & 60 & 60 & 60 \\
\hline Real interest rate (\%) & 2.4 & 1.7 & 1.4 & 3.1 & 3.7 & 4.5 & 4.7 & 5.1 \\
\hline Total national saving & 14.7 & 12.5 & 12.7 & 15.6 & 11.8 & 10.9 & 11.1 & 10.8 \\
\hline Total investment & 19.7 & 15.8 & 17.0 & 17.4 & 16.1 & 13.8 & 12.8 & 11.6 \\
\hline Current balance & -4.9 & -3.2 & -4.3 & -1.8 & -4.3 & -2.8 & -1.7 & -0.7 \\
\hline \multicolumn{9}{|l|}{ Japan } \\
\hline Potential real GDP growth (\%) & 0.7 & 0.6 & 0.8 & 1.4 & 1.8 & 1.6 & 1.9 & 1.9 \\
\hline Fiscal balance & -5.4 & -8.4 & -10.1 & 0.4 & 11.0 & 2.1 & 0.7 & 0.6 \\
\hline Gross government debt & 157 & 193 & 223 & 229 & 122 & 66 & 60 & 60 \\
\hline Real interest rate $(\%)$ & 2.7 & 2.4 & 3.0 & 2.8 & 3.3 & 4.0 & 4.4 & 5.1 \\
\hline Total national saving & 26.4 & 23.2 & 22.4 & 26.4 & 31.6 & 23.9 & 22.0 & 22.7 \\
\hline Total investment & 23.1 & 19.8 & 20.6 & 23.6 & 26.2 & 22.0 & 21.8 & 20.0 \\
\hline Current balance & 3.3 & 3.6 & 1.9 & 2.9 & 5.6 & 1.9 & 0.3 & 2.7 \\
\hline \multicolumn{9}{|l|}{ Euro Area } \\
\hline Potential real GDP growth (\%) & 1.9 & 1.0 & 1.3 & 2.3 & 1.9 & 1.7 & 1.7 & 1.7 \\
\hline Fiscal balance & -2.0 & -6.3 & -2.0 & 1.8 & -0.5 & -0.8 & -0.9 & -0.9 \\
\hline Gross government debt & 76 & 93 & 100 & 77 & 61 & 60 & 60 & 60 \\
\hline Real interest rate $(\%)$ & 2.3 & 2.3 & 3.3 & 3.0 & 3.4 & 4.0 & 4.3 & 4.8 \\
\hline Total national saving & 21.5 & 19.3 & 20.4 & 19.8 & 15.7 & 13.2 & 12.8 & 13.4 \\
\hline Total investment & 21.3 & 19.3 & 18.9 & 22.2 & 19.0 & 15.9 & 15.3 & 14.2 \\
\hline Current balance & 0.3 & 0.4 & 1.5 & -2.3 & -3.4 & -2.9 & -2.5 & -0.7 \\
\hline \multicolumn{9}{|l|}{ OECD Total } \\
\hline Potential real GDP growth (\%) & & 1.6 & 2.0 & 2.6 & 2.3 & 2.1 & 2.0 & 1.9 \\
\hline Fiscal balance & -2.1 & -7.8 & -4.4 & 1.8 & 0.6 & -0.5 & -0.6 & -0.5 \\
\hline Gross government debt & 74 & 99 & 109 & 92 & 64 & 57 & 57 & 57 \\
\hline Real interest rate $(\%)$ & 2.5 & 1.9 & 2.3 & 3.1 & 3.6 & 4.3 & 4.6 & 5.1 \\
\hline Total national saving & 19.8 & 18.0 & 18.8 & 20.1 & 17.5 & 15.1 & 14.4 & 14.0 \\
\hline Total investment & 21.0 & 18.6 & 19.5 & 20.6 & 18.7 & 16.0 & 15.1 & 13.8 \\
\hline Current balance & -1.2 & -0.6 & -0.8 & -0.6 & -1.4 & -1.1 & -0.9 & 0.0 \\
\hline \multicolumn{9}{|l|}{ China } \\
\hline Potential real GDP growth (\%) & 10.0 & 10.2 & 9.5 & 7.2 & 4.3 & 3.5 & 2.0 & 1.5 \\
\hline Total national saving & 44.6 & 51.8 & 50.1 & 37.9 & 27.2 & 19.2 & 16.2 & 10.2 \\
\hline Total investment & 40.1 & 47.8 & 48.3 & 39.7 & 27.4 & 22.3 & 16.4 & 13.9 \\
\hline Current balance & 4.6 & 4.0 & 1.7 & -1.8 & -0.3 & -3.2 & -0.2 & -3.7 \\
\hline \multicolumn{9}{|l|}{ India } \\
\hline Potential real GDP growth (\%) & 7.4 & 7.8 & 7.3 & 7.1 & 6.1 & 4.8 & 3.8 & 3.0 \\
\hline Total national saving & 29.6 & 31.8 & 28.3 & 27.6 & 23.2 & 21.9 & 20.4 & 17.9 \\
\hline Total investment & 27.1 & 31.1 & 28.4 & 27.8 & 24.3 & 20.0 & 17.2 & 14.8 \\
\hline Current balance & 0.0 & -3.2 & -2.9 & -3.1 & -4.0 & -1.0 & 0.2 & 0.2 \\
\hline \multicolumn{9}{|l|}{ Brazil } \\
\hline Potential real GDP growth (\%) & 3.1 & 4.2 & 4.5 & 4.4 & 3.9 & 2.8 & 2.3 & 1.1 \\
\hline Total national saving & 16.1 & 17.5 & 16.7 & 16.2 & 13.7 & 11.5 & 8.7 & 6.1 \\
\hline Total investment & 16.4 & 19.5 & 20.3 & 19.4 & 16.9 & 13.6 & 12.0 & 9.2 \\
\hline Current balance & 0.7 & -2.2 & -3.2 & -3.4 & -3.6 & -2.5 & -3.7 & -3.5 \\
\hline \multicolumn{9}{|l|}{ Russia } \\
\hline Potential real GDP growth (\%) & 5.3 & 4.3 & 4.1 & 3.2 & 2.7 & 0.9 & 1.5 & 2.7 \\
\hline \multicolumn{9}{|l|}{ Potential real GDP growth (\%) } \\
\hline $\mathrm{OECD}$ & 2.3 & 1.6 & 2.0 & 2.6 & 2.3 & 2.1 & 2.0 & $\overline{1.9}$ \\
\hline non - OECD & 7.0 & 7.8 & 7.6 & 6.4 & 4.6 & 3.6 & 2.6 & 2.1 \\
\hline World & 3.5 & 3.6 & 4.0 & 4.2 & 3.5 & 2.9 & 2.3 & 2.0 \\
\hline \multicolumn{9}{|l|}{ Share of real world GDP in 2005 PPPs (\%) } \\
\hline United States & 26.3 & 23.2 & 22.1 & 19.7 & 17.4 & 15.9 & 15.1 & 14.7 \\
\hline Japan & 8.3 & 7.0 & 6.4 & 4.8 & 3.9 & 3.4 & 3.1 & 3.0 \\
\hline Euro Area & 20.2 & 17.4 & 16.0 & 14.1 & 12.0 & 10.5 & 9.6 & 9.1 \\
\hline OECD & 74.1 & 65.9 & 62.4 & 55.5 & 48.8 & 44.3 & 41.9 & 40.9 \\
\hline China & 10.3 & 16.2 & 18.7 & 24.2 & 28.1 & 30.2 & 30.3 & 29.0 \\
\hline India & 4.8 & 6.4 & 7.1 & 8.5 & 11.0 & 13.6 & 15.9 & 18.0 \\
\hline Brazil & 3.3 & 3.5 & 3.5 & 3.5 & 3.6 & 3.7 & 3.6 & 3.4 \\
\hline Russia & 3.4 & 3.6 & 3.6 & 3.5 & 3.2 & 2.8 & 2.4 & 2.5 \\
\hline non-OECD & 25.9 & 34.1 & 37.6 & 44.5 & 51.2 & 55.7 & 58.1 & 59.1 \\
\hline
\end{tabular}


Table 3(b). Detailed country results with more ambitious fiscal consolidation and structural reforms $\%$ of GDP unless otherwise stated

\begin{tabular}{|c|c|c|c|c|c|c|c|c|}
\hline & Avg 2000-07 & 2010 & 2013 & 2020 & 2030 & 2040 & 2050 & 2060 \\
\hline \multicolumn{9}{|l|}{ Australia } \\
\hline Potential real GDP growth (\%) & 3.3 & 3.0 & 3.5 & 3.4 & 2.9 & 2.6 & 2.4 & 2.3 \\
\hline Fiscal balance & 1.6 & -4.7 & 0.4 & -0.6 & -0.4 & -0.4 & -0.4 & -0.3 \\
\hline Gross government debt & 19 & 24 & 28 & 28 & 29 & 29 & 29 & 29 \\
\hline Real interest rate (\%) & 2.3 & 0.9 & 1.9 & 3.6 & 4.3 & 5.0 & 5.1 & 5.5 \\
\hline Total national saving & 21.6 & 24.0 & 25.7 & 23.7 & 21.6 & 19.7 & 19.0 & 18.0 \\
\hline Total investment & 26.3 & 26.8 & 30.3 & 26.1 & 21.8 & 18.5 & 17.1 & 15.6 \\
\hline Current balance & -4.8 & -2.8 & -4.7 & -2.4 & -0.2 & 1.2 & 2.0 & 2.4 \\
\hline \multicolumn{9}{|l|}{ Austria } \\
\hline Potential real GDP growth (\%) & 2.1 & 1.7 & 1.7 & 2.0 & 1.7 & 1.8 & 1.8 & 1.7 \\
\hline Fiscal balance & -1.7 & -4.5 & -2.3 & 0.8 & -0.7 & -0.9 & -0.9 & -0.9 \\
\hline Gross government debt & 70 & 78 & 84 & 70 & 61 & 60 & 60 & 60 \\
\hline Real interest rate (\%) & 3.1 & 1.6 & 2.0 & 2.6 & 3.3 & 4.0 & 4.3 & 4.8 \\
\hline Total national saving & 25.6 & 25.7 & 26.3 & 25.7 & 21.9 & 19.3 & 18.9 & 19.1 \\
\hline Total investment & 23.1 & 21.7 & 23.7 & 23.5 & 20.9 & 19.0 & 18.2 & 16.7 \\
\hline Current balance & 1.7 & 3.0 & 2.5 & 2.2 & 1.0 & 0.3 & 0.7 & 2.3 \\
\hline \multicolumn{9}{|l|}{ Belgium } \\
\hline Potential real GDP growth (\%) & 1.8 & 1.2 & 1.5 & 2.9 & 2.6 & 2.5 & 2.5 & 2.5 \\
\hline Fiscal balance & -0.3 & -3.9 & -2.2 & 0.9 & -1.5 & -1.8 & -1.8 & -1.7 \\
\hline Gross government debt & 101 & 100 & 102 & 75 & 61 & 60 & 60 & 60 \\
\hline Real interest rate (\%) & 2.5 & 1.6 & 2.3 & 2.7 & 3.3 & 4.0 & 4.3 & 4.8 \\
\hline Total national saving & 25.7 & 23.5 & 23.1 & 23.5 & 20.0 & 18.9 & 19.4 & 20.0 \\
\hline Total investment & 21.4 & 20.3 & 21.0 & 25.7 & 22.8 & 20.4 & 19.4 & 18.0 \\
\hline Current balance & 3.3 & 1.3 & -0.3 & -3.9 & -3.9 & -2.2 & -0.4 & 1.8 \\
\hline \multicolumn{9}{|l|}{ Canada } \\
\hline Potential real GDP growth (\%) & 2.7 & 1.6 & 2.2 & 2.3 & 2.1 & 2.3 & 2.4 & 2.3 \\
\hline Fiscal balance & 1.1 & -5.6 & -2.4 & 0.9 & -0.4 & -0.6 & -0.7 & -0.6 \\
\hline Gross government debt & 76 & 84 & 81 & 69 & 61 & 60 & 60 & 60 \\
\hline Real interest rate (\%) & 2.4 & 1.3 & 0.7 & 2.3 & 3.3 & 4.5 & 4.9 & 5.5 \\
\hline Total national saving & 22.8 & 19.2 & 21.0 & 22.6 & 20.0 & 18.6 & 18.4 & 17.9 \\
\hline Total investment & 21.0 & 22.2 & 23.3 & 21.4 & 18.3 & 16.7 & 16.2 & 14.6 \\
\hline Current balance & 1.8 & -3.1 & -2.3 & 1.2 & 1.8 & 1.9 & 2.2 & 3.3 \\
\hline \multicolumn{9}{|l|}{ Chile } \\
\hline Potential real GDP growth (\%) & 3.8 & 3.5 & 5.2 & 4.4 & 3.2 & 2.6 & 2.0 & 1.6 \\
\hline Total national saving & 22.4 & 25.0 & 25.1 & 23.2 & 18.2 & 14.3 & 11.3 & 5.9 \\
\hline Total investment & 969 & 21 & 25 & 23 & 19 & 16 & 14 & 13 \\
\hline Current balance & 1.0 & 1.5 & -0.1 & -0.8 & -1.7 & -2.7 & -3.6 & -7.3 \\
\hline \multicolumn{9}{|l|}{ Czech Republic } \\
\hline Potential real GDP growth (\%) & 3.7 & 1.9 & 1.9 & 3.6 & 2.8 & 2.0 & 2.3 & 2.2 \\
\hline Fiscal balance & -3.9 & -4.8 & -2.2 & -0.4 & -0.5 & -0.4 & -0.5 & -0.5 \\
\hline Gross government debt & 32 & 45 & 53 & 53 & 52 & 52 & 52 & 52 \\
\hline Real interest rate (\%) & 2.4 & 3.0 & 3.7 & 3.7 & 4.3 & 4.6 & 4.8 & 5.3 \\
\hline Total national saving & 24.6 & 21.0 & 22.2 & 21.6 & 19.3 & 17.0 & 15.2 & 14.9 \\
\hline Total investment & 28.3 & 25.1 & 23.8 & 27.7 & 22.9 & 18.4 & 18.2 & 16.7 \\
\hline Current balance & -4.2 & -3.8 & -1.6 & -6.2 & -3.6 & -1.4 & -3.0 & -1.8 \\
\hline \multicolumn{9}{|l|}{ Denmark } \\
\hline Potential real GDP growth (\%) & 1.6 & 0.6 & 0.7 & 1.4 & 1.9 & 2.2 & 2.3 & 2.1 \\
\hline Fiscal balance & 2.5 & -2.7 & -2.0 & 0.3 & -0.1 & -0.2 & -0.2 & -0.2 \\
\hline Gross government debt & 51 & 55 & 65 & 63 & 60 & 60 & 60 & 60 \\
\hline Real interest rate (\%) & 2.2 & -0.2 & 1.1 & 1.8 & 3.0 & 4.3 & 4.9 & 5.3 \\
\hline Total national saving & 23.7 & 22.4 & 23.3 & 22.8 & 22.2 & 21.5 & 21.6 & 21.5 \\
\hline Total investment & 21.1 & 17.2 & 17.9 & 18.5 & 18.0 & 17.0 & 16.5 & 14.9 \\
\hline Current balance & 2.7 & 5.5 & 5.4 & 4.3 & 4.2 & 4.5 & 5.0 & 6.6 \\
\hline \multicolumn{9}{|l|}{ Estonia } \\
\hline Potential real GDP growth (\%) & 4.9 & 0.4 & 2.6 & 3.5 & 2.5 & 2.4 & 2.1 & 2.1 \\
\hline Fiscal balance & 1.2 & 0.3 & -0.3 & 1.0 & 1.0 & 1.0 & 0.9 & 0.9 \\
\hline Gross government debt & 9 & 12 & 13 & 18 & 18 & 18 & 18 & 18 \\
\hline Real interest rate (\%) & -2.0 & -2.7 & -2.4 & 1.7 & 3.2 & 4.0 & 4.3 & 4.8 \\
\hline Total national saving & 22.6 & 23.2 & 25.0 & 25.9 & 23.4 & 21.7 & 21.6 & 20.6 \\
\hline Total investment & 33.2 & 20.1 & 24.3 & 24.2 & 19.5 & 17.1 & 15.7 & 14.7 \\
\hline Current balance & -10.6 & 3.6 & 0.7 & 1.7 & 4.0 & 4.6 & 5.8 & 5.9 \\
\hline \multicolumn{9}{|l|}{ Finland } \\
\hline Potential real GDP growth (\%) & 2.7 & 0.9 & 1.6 & 2.7 & 1.9 & 1.7 & 1.7 & 1.6 \\
\hline Fiscal balance & 4.1 & -2.9 & 0.0 & 2.7 & 2.1 & 1.9 & 1.9 & 1.8 \\
\hline Gross government debt & 49 & 58 & 62 & 62 & 60 & 60 & 60 & 60 \\
\hline Real interest rate (\%) & 3.1 & 1.3 & 0.1 & 2.5 & 3.3 & 4.0 & 4.3 & 4.8 \\
\hline Total national saving & 26.3 & 20.4 & 20.4 & 20.3 & 17.7 & 17.1 & 17.2 & 17.0 \\
\hline Total investment & 20.7 & 19.4 & 21.0 & 23.5 & 19.5 & 16.9 & 16.2 & 14.9 \\
\hline Current balance & 5.9 & 1.7 & -0.7 & -3.1 & -1.8 & 0.2 & 1.0 & 2.1 \\
\hline
\end{tabular}


Table 3(b). Detailed country results with more ambitious fiscal consolidation and structural reforms (contd.) $\%$ of GDP unless otherwise stated

\begin{tabular}{|c|c|c|c|c|c|c|c|c|}
\hline & Avg 2000-07 & 2010 & 2013 & 2020 & 2030 & 2040 & 2050 & 2060 \\
\hline \multicolumn{9}{|l|}{ France } \\
\hline Potential real GDP growth (\%) & 1.8 & 1.3 & 1.6 & 2.9 & 2.3 & 1.8 & 1.8 & 1.7 \\
\hline Fiscal balance & -2.8 & -7.1 & -3.0 & 2.5 & -0.3 & -0.7 & -0.7 & -0.7 \\
\hline Gross government debt & 70 & 96 & 107 & 83 & 62 & 60 & 60 & 60 \\
\hline Real interest rate (\%) & 2.6 & 1.7 & 2.1 & 2.8 & 3.3 & 4.0 & 4.3 & 4.8 \\
\hline Total national saving & 20.2 & 17.4 & 18.6 & 19.1 & 15.1 & 13.5 & 13.6 & 13.5 \\
\hline Total investment & 19.8 & 19.2 & 20.2 & 24.4 & 20.8 & 17.2 & 16.3 & 15.0 \\
\hline Current balance & 0.5 & -1.8 & -1.7 & -5.3 & -5.7 & -3.7 & -2.7 & -1.5 \\
\hline \multicolumn{9}{|l|}{ Germany } \\
\hline Potential real GDP growth (\%) & 1.4 & 1.1 & 1.7 & 1.7 & 1.1 & 1.3 & 1.4 & 1.2 \\
\hline Fiscal balance & -2.3 & -4.3 & -0.6 & 0.9 & -0.5 & -0.7 & -0.7 & -0.7 \\
\hline Gross government debt & 66 & 87 & 88 & 69 & 61 & 60 & 60 & 60 \\
\hline Real interest rate (\%) & 3.6 & 1.9 & 1.1 & 2.4 & 3.3 & 4.0 & 4.3 & 4.8 \\
\hline Total national saving & 22.1 & 23.1 & 23.8 & 23.1 & 19.2 & 16.9 & 17.4 & 18.7 \\
\hline Total investment & 18.9 & 17.3 & 18.2 & 18.6 & 15.3 & 14.1 & 13.5 & 12.2 \\
\hline Current balance & 3.2 & 6.0 & 5.5 & 4.5 & 3.9 & 2.8 & 3.9 & 6.5 \\
\hline \multicolumn{9}{|l|}{ Greece } \\
\hline Potential real GDP growth (\%) & 3.1 & -0.4 & -0.4 & 3.3 & 2.2 & 1.3 & 1.6 & 1.9 \\
\hline Fiscal balance & -5.6 & -10.5 & -4.9 & 5.5 & 0.3 & -0.8 & -1.0 & -1.1 \\
\hline Gross government debt & 116 & 150 & 173 & 122 & 65 & 60 & 60 & 60 \\
\hline Real interest rate (\%) & 1.4 & 5.9 & 21.7 & 7.6 & 3.7 & 4.1 & 4.3 & 4.8 \\
\hline Total national saving & 11.9 & 3.8 & 4.7 & 12.0 & 6.6 & 3.3 & 2.0 & 2.9 \\
\hline Total investment & 24.5 & 16.2 & 13.0 & 21.8 & 19.3 & 14.2 & 14.1 & 13.6 \\
\hline Current balance & -8.5 & -10.1 & -6.5 & -8.6 & -12.0 & -10.4 & -11.7 & -10.5 \\
\hline \multicolumn{9}{|l|}{ Hungary } \\
\hline Potential real GDP growth (\%) & 2.8 & 0.8 & 0.9 & 3.7 & 2.9 & 2.2 & 2.1 & 2.0 \\
\hline Fiscal balance & -6.5 & -4.3 & -2.9 & -0.4 & -1.6 & -1.5 & -1.5 & -1.4 \\
\hline Gross government debt & 65 & 86 & 84 & 68 & 60 & 60 & 60 & 60 \\
\hline Real interest rate $(\%)$ & 0.2 & 3.3 & 3.2 & 4.0 & 4.5 & 4.8 & 4.8 & 5.2 \\
\hline Total national saving & 17.7 & 20.2 & 22.8 & 22.6 & 20.9 & 19.2 & 17.6 & 17.5 \\
\hline Total investment & 25.1 & 18.8 & 19.0 & 24.5 & 20.5 & 17.0 & 15.9 & 14.6 \\
\hline Current balance & -7.5 & 1.2 & 3.8 & -1.9 & 0.4 & 2.2 & 1.8 & 2.8 \\
\hline \multicolumn{9}{|l|}{ Iceland } \\
\hline Potential real GDP growth (\%) & 3.7 & 0.9 & 1.4 & 2.4 & 2.8 & 2.4 & 2.3 & 2.3 \\
\hline Fiscal balance & 1.5 & -10.1 & -1.4 & 5.2 & 1.8 & 0.9 & 0.9 & 0.9 \\
\hline Gross government debt & 65 & 125 & 125 & 95 & 63 & 60 & 60 & 60 \\
\hline Real interest rate (\%) & 4.4 & -3.2 & 2.5 & 3.5 & 4.0 & 4.8 & 4.9 & 5.5 \\
\hline Total national saving & 14.2 & 4.6 & 16.2 & 18.2 & 13.7 & 11.0 & 9.6 & 8.4 \\
\hline Total investment & 24.8 & 12.6 & 17.3 & 20.1 & 19.8 & 16.9 & 15.6 & 14.6 \\
\hline Current balance & -10.4 & -8.0 & -1.1 & -1.9 & -6.1 & -5.8 & -6.0 & -6.2 \\
\hline \multicolumn{9}{|l|}{ Italy } \\
\hline Potential real GDP growth (\%) & 1.2 & 0.2 & 0.3 & 2.1 & 2.4 & 2.2 & 2.0 & 1.8 \\
\hline Fiscal balance & -3.0 & -4.5 & -0.6 & 2.8 & -1.0 & -1.4 & -1.3 & -1.2 \\
\hline Gross government debt & 118 & 126 & 122 & 81 & 61 & 60 & 60 & 60 \\
\hline Real interest rate (\%) & 2.1 & 2.3 & 5.0 & 3.5 & 3.4 & 4.0 & 4.3 & 4.8 \\
\hline Total national saving & 19.9 & 16.6 & 16.2 & 14.8 & 10.2 & 6.8 & 6.3 & 7.8 \\
\hline Total investment & 21.2 & 20.2 & 17.9 & 24.8 & 23.6 & 20.3 & 18.7 & 16.8 \\
\hline Current balance & -1.3 & -3.5 & -1.7 & -9.9 & -13.4 & -13.5 & -12.4 & -9.0 \\
\hline \multicolumn{9}{|l|}{ Japan } \\
\hline Potential real GDP growth (\%) & 0.7 & 0.6 & 0.8 & 1.4 & 1.8 & 1.6 & 1.9 & 1.9 \\
\hline Fiscal balance & -5.4 & -8.4 & -10.1 & 0.4 & 11.0 & 2.1 & 0.7 & 0.6 \\
\hline Gross government debt & 157 & 193 & 223 & 229 & 122 & 66 & 60 & 60 \\
\hline Real interest rate (\%) & 2.7 & 2.4 & 3.0 & 2.8 & 3.3 & 4.0 & 4.4 & 5.1 \\
\hline Total national saving & 26.4 & 23.2 & 22.4 & 26.4 & 31.6 & 23.9 & 22.0 & 22.7 \\
\hline Total investment & 23.1 & 19.8 & 20.6 & 23.6 & 26.2 & 22.0 & 21.8 & 20.0 \\
\hline Current balance & 3.3 & 3.6 & 1.9 & 2.9 & 5.6 & 1.9 & 0.3 & 2.7 \\
\hline \multicolumn{9}{|l|}{ Korea } \\
\hline Potential real GDP growth (\%) & 4.5 & 3.7 & 3.5 & 3.4 & 2.3 & 1.7 & 1.6 & 1.4 \\
\hline Fiscal balance & 3.8 & 1.3 & 2.8 & 2.3 & 2.0 & 1.7 & 1.7 & 1.6 \\
\hline Gross government debt & 23 & 35 & 34 & 34 & 34 & 34 & 34 & 34 \\
\hline Real interest rate (\%) & 3.8 & 1.5 & 3.3 & 3.7 & 4.0 & 4.2 & 4.2 & 4.6 \\
\hline Total national saving & 31.6 & 32.0 & 31.6 & 29.4 & 24.7 & 19.8 & 17.1 & 16.8 \\
\hline Total investment & 29.6 & 29.6 & 29.9 & 28.6 & 24.8 & 21.7 & 20.4 & 18.8 \\
\hline Current balance & 2.3 & 2.9 & 1.6 & 0.8 & 0.0 & -1.9 & -3.3 & -2.0 \\
\hline \multicolumn{9}{|l|}{ Mexico } \\
\hline Potential real GDP growth (\%) & 2.5 & 2.2 & 3.1 & 3.8 & 3.6 & 3.3 & 2.8 & 2.6 \\
\hline Total national saving & 24.1 & 23.6 & 25.6 & 25.4 & 23.6 & 19.8 & 16.2 & 11.8 \\
\hline Total investment & 20 & 21 & 22 & 22 & 20 & 17 & 16 & 14 \\
\hline Current balance & -1.4 & -0.3 & -0.4 & -1.0 & -0.6 & -1.9 & -3.8 & -6.6 \\
\hline
\end{tabular}


ECO/WKP(2012)77

Table 3(b). Detailed country results with more ambitious fiscal consolidation and structural reforms (contd.)

\begin{tabular}{|c|c|c|c|c|c|c|c|c|}
\hline & \multicolumn{5}{|c|}{$\%$ of GDP unless otherwise stated } & \multirow[b]{2}{*}{2040} & \multirow[b]{2}{*}{2050} & \multirow[b]{2}{*}{2060} \\
\hline & Avg 2000-07 & 2010 & 2013 & 2020 & 2030 & & & \\
\hline \multicolumn{9}{|l|}{ Norway } \\
\hline Potential real GDP growth (\%) & 3.0 & 2.3 & 2.8 & 3.2 & 2.4 & 2.1 & 2.0 & 1.8 \\
\hline Fiscal balance & 13.4 & 11.2 & 16.3 & 16.3 & 16.3 & 16.3 & 16.3 & 16.3 \\
\hline Gross government debt & 46 & 50 & 20 & 20 & 20 & 20 & 20 & 20 \\
\hline Total national saving & 35.0 & 34.9 & 39.3 & 36.9 & 33.7 & 31.0 & 30.7 & 30.0 \\
\hline Total investment & 20.9 & 22.4 & 23.3 & 22.7 & 19.2 & 17.0 & 16.1 & 14.8 \\
\hline Current balance & 14.2 & 12.4 & 16.0 & 14.1 & 14.5 & 13.9 & 14.7 & 15.2 \\
\hline \multicolumn{9}{|l|}{ New Zealand } \\
\hline Potential real GDP growth (\%) & 3.1 & 1.3 & 2.2 & 3.0 & 2.9 & 2.9 & 2.8 & 2.6 \\
\hline Fiscal balance & 3.7 & -4.2 & -2.9 & -0.6 & -0.8 & -0.8 & -0.8 & -0.8 \\
\hline Gross government debt & 30 & 37 & 51 & 52 & 50 & 50 & 50 & 50 \\
\hline Real interest rate (\%) & 3.8 & 3.0 & 2.5 & 3.3 & 4.2 & 5.2 & 5.4 & 5.8 \\
\hline Total national saving & 17.5 & 16.2 & 16.6 & 17.3 & 14.9 & 13.1 & 12.8 & 12.0 \\
\hline Total investment & 23.1 & 19.7 & 22.9 & 22.7 & 20.5 & 18.8 & 17.6 & 16.0 \\
\hline Current balance & -5.5 & -3.4 & -6.2 & -5.4 & -5.6 & -5.8 & -4.8 & -4.1 \\
\hline \multicolumn{9}{|l|}{ Poland } \\
\hline Potential real GDP growth (\%) & 4.2 & 3.1 & 3.4 & 3.1 & 2.1 & 1.6 & 1.4 & 1.5 \\
\hline Fiscal balance & -4.3 & -7.9 & -2.2 & -1.6 & -1.4 & -1.3 & -1.2 & -1.2 \\
\hline Gross government debt & 52 & 62 & 62 & 61 & 60 & 60 & 60 & 60 \\
\hline Real interest rate (\%) & 3.4 & 3.0 & 2.8 & 3.8 & 3.8 & 4.1 & 4.1 & 4.6 \\
\hline Total national saving & 17.0 & 16.8 & 18.8 & 18.1 & 15.4 & 13.3 & 10.9 & 9.7 \\
\hline Total investment & 20.9 & 20.8 & 23.0 & 22.1 & 19.0 & 16.6 & 15.4 & 14.7 \\
\hline Current balance & -4.0 & -4.6 & -4.1 & -4.0 & -3.6 & -3.3 & -4.6 & -4.9 \\
\hline \multicolumn{9}{|l|}{ Portugal } \\
\hline Potential real GDP growth (\%) & 1.8 & 0.4 & 0.3 & 2.2 & 2.3 & 1.8 & 1.8 & 1.8 \\
\hline Fiscal balance & -4.2 & -9.8 & -3.5 & 4.7 & 0.2 & -0.5 & -0.6 & -0.6 \\
\hline Gross government debt & 68 & 103 & 130 & 95 & 63 & 60 & 60 & 60 \\
\hline Real interest rate (\%) & 1.4 & 4.2 & 12.3 & 5.1 & 3.5 & 4.0 & 4.3 & 4.8 \\
\hline Total national saving & 15.4 & 9.1 & 13.9 & 13.6 & 8.2 & 5.2 & 2.5 & 2.7 \\
\hline Total investment & 24.8 & 19.6 & 16.6 & 21.6 & 21.0 & 17.8 & 17.0 & 15.8 \\
\hline Current balance & -9.3 & -10.0 & -2.2 & -7.7 & -12.6 & -12.5 & -14.4 & -13.0 \\
\hline \multicolumn{9}{|l|}{ Slovak Republic } \\
\hline Potential real GDP growth (\%) & 4.6 & 2.8 & 3.3 & 3.6 & 2.6 & 1.9 & 1.8 & 1.6 \\
\hline Fiscal balance & -5.0 & -7.7 & -2.9 & -1.7 & -1.4 & -1.2 & -1.2 & -1.1 \\
\hline Gross government debt & 46 & 47 & 54 & 55 & 55 & 55 & 55 & 55 \\
\hline Real interest rate (\%) & 0.8 & 2.9 & 3.4 & 2.8 & 3.4 & 4.0 & 4.3 & 4.8 \\
\hline Total national saving & 20.2 & 19.6 & 23.7 & 22.5 & 20.3 & 17.8 & 15.5 & 14.7 \\
\hline Total investment & 27.5 & 23.4 & 21.4 & 22.9 & 18.7 & 15.1 & 14.3 & 12.9 \\
\hline Current balance & -6.9 & -2.5 & 2.3 & -0.3 & 1.6 & 2.7 & 1.2 & 1.7 \\
\hline \multicolumn{9}{|l|}{ Slovenia } \\
\hline Potential real GDP growth (\%) & & 0.9 & 0.9 & 2.9 & 2.2 & 2.3 & 1.9 & 1.8 \\
\hline Fiscal balance & -2.2 & -6.0 & -3.0 & -0.1 & -0.4 & -0.4 & -0.4 & -0.4 \\
\hline Gross government debt & 34 & 48 & 63 & 63 & 60 & 60 & 60 & 60 \\
\hline Real interest rate (\%) & 0.3 & 1.6 & 5.2 & 3.2 & 3.4 & 4.0 & 4.3 & 4.8 \\
\hline Total national saving & 25.3 & 22.1 & 21.5 & 19.2 & 15.8 & 14.0 & 13.1 & 13.5 \\
\hline Total investment & 27.2 & 22.6 & 20.1 & 25.4 & 21.2 & 19.3 & 17.6 & 16.2 \\
\hline Current balance & -1.8 & -0.8 & 1.4 & -6.1 & -5.4 & -5.2 & -4.5 & -2.6 \\
\hline \multicolumn{9}{|l|}{ Spain } \\
\hline Potential real GDP growth (\%) & 3.5 & 1.3 & 1.2 & 2.6 & 2.0 & 1.2 & 1.4 & 1.9 \\
\hline Fiscal balance & 0.4 & -9.3 & -3.3 & 1.0 & -0.8 & -0.8 & -0.9 & -1.0 \\
\hline Gross government debt & 55 & 67 & 91 & 74 & 61 & 60 & 60 & 60 \\
\hline Real interest rate $(\%)$ & 0.6 & 3.2 & 4.7 & 3.2 & 3.4 & 4.0 & 4.3 & 4.8 \\
\hline Total national saving & 22.3 & 18.6 & 20.2 & 17.5 & 13.5 & 10.4 & 8.5 & 9.3 \\
\hline Total investment & 28.3 & 23.3 & 20.1 & 23.6 & 18.5 & 12.8 & 13.0 & 13.5 \\
\hline Current balance & -5.8 & -4.5 & 0.1 & -6.1 & -5.0 & -2.5 & -4.5 & -4.2 \\
\hline Sweden & & & & & & & & \\
\hline Potential real GDP growth (\%) & 2.6 & 2.0 & 2.4 & 2.8 & 2.1 & 2.0 & 2.0 & 1.9 \\
\hline Fiscal balance & 1.3 & -0.1 & 0.3 & 1.1 & 0.8 & 0.8 & 0.8 & 0.8 \\
\hline Gross government debt & 59 & 49 & 46 & 46 & 45 & 45 & 45 & 45 \\
\hline Real interest rate (\%) & 3.1 & 0.6 & 1.6 & 3.0 & 3.6 & 4.3 & 4.6 & 5.1 \\
\hline Total national saving & 24.9 & 25.4 & 26.5 & 26.3 & 24.8 & 23.2 & 23.4 & 22.5 \\
\hline Total investment & 18.2 & 18.6 & 20.2 & 19.4 & 16.1 & 14.3 & 13.7 & 12.5 \\
\hline Current balance & 6.2 & 6.9 & 6.3 & 6.9 & 8.7 & 8.9 & 9.6 & 10.0 \\
\hline
\end{tabular}


Table 3(b). Detailed country results with more ambitious fiscal consolidation and structural reforms (contd.) $\%$ of GDP unless otherwise stated

\begin{tabular}{|c|c|c|c|c|c|c|c|c|}
\hline & Avg 2000-07 & 2010 & 2013 & 2020 & 2030 & 2040 & 2050 & 2060 \\
\hline \multicolumn{9}{|l|}{ Switzerland } \\
\hline Potential real GDP growth (\%) & 1.8 & 1.7 & 2.0 & 2.5 & 2.2 & 2.2 & 2.1 & 2.0 \\
\hline Fiscal balance & -0.4 & 0.6 & 0.6 & 0.1 & 0.2 & 0.2 & 0.2 & 0.2 \\
\hline Gross government debt & 54 & 42 & 39 & 39 & 39 & 39 & 39 & 39 \\
\hline Real interest rate (\%) & 2.1 & 0.6 & 1.3 & 2.4 & 3.6 & 4.5 & 4.8 & 5.2 \\
\hline Total national saving & 32.7 & 34.1 & 36.3 & 35.0 & 33.1 & 29.9 & 28.9 & 29.0 \\
\hline Total investment & 21.9 & 19.2 & 19.7 & 20.9 & 18.6 & 16.8 & 15.7 & 14.3 \\
\hline Current balance & 11.7 & 15.2 & 16.5 & 14.1 & 14.4 & 13.1 & 13.2 & 14.7 \\
\hline \multicolumn{9}{|l|}{ United Kingdom } \\
\hline Potential real GDP growth (\%) & 2.5 & 0.9 & 1.3 & 2.2 & 2.2 & 2.2 & 2.3 & 2.1 \\
\hline Fiscal balance & -1.7 & -10.3 & -6.6 & 2.7 & -0.4 & -1.2 & -1.3 & -1.2 \\
\hline Gross government debt & 44 & 82 & 108 & 92 & 63 & 60 & 60 & 60 \\
\hline Real interest rate (\%) & 2.8 & 1.0 & 1.7 & 3.0 & 3.5 & 4.5 & 4.9 & 5.3 \\
\hline Total national saving & 15.1 & 11.8 & 14.2 & 18.7 & 15.8 & 14.3 & 14.2 & 13.5 \\
\hline Total investment & 17.4 & 15.1 & 15.2 & 15.6 & 14.1 & 12.3 & 11.8 & 10.7 \\
\hline Current balance & -2.3 & -3.3 & -1.0 & 3.0 & 1.7 & 1.9 & 2.4 & 2.9 \\
\hline \multicolumn{9}{|l|}{ United States } \\
\hline Potential real GDP growth (\%) & 2.6 & 1.7 & 2.1 & 2.5 & 2.4 & 2.1 & 2.0 & 1.9 \\
\hline Fiscal balance & -2.6 & -10.7 & -6.5 & 2.4 & -0.9 & -1.5 & -1.5 & -1.4 \\
\hline Gross government debt & 62 & 98 & 111 & 90 & 62 & 60 & 60 & 60 \\
\hline Real interest rate (\%) & 2.4 & 1.7 & 1.4 & 3.1 & 3.7 & 4.5 & 4.7 & 5.1 \\
\hline Total national saving & 14.7 & 12.5 & 12.7 & 15.6 & 11.8 & 10.9 & 11.1 & 10.8 \\
\hline Total investment & 19.7 & 15.8 & 17.0 & 17.4 & 16.1 & 13.8 & 12.8 & 11.6 \\
\hline Current balance & -4.9 & -3.2 & -4.3 & -1.8 & -4.3 & -2.8 & -1.7 & -0.7 \\
\hline \multicolumn{9}{|l|}{ Turkey } \\
\hline Potential real GDP growth (\%) & 4.0 & 4.6 & 5.5 & 4.8 & 3.6 & 2.5 & 1.8 & 1.8 \\
\hline Total national saving & 16.5 & 13.2 & 16.5 & 14.7 & 14.1 & 12.3 & 9.4 & 7.0 \\
\hline Total investment & 19.4 & 18.9 & 22.6 & 20.7 & 17.0 & 13.6 & 11.7 & 10.8 \\
\hline Current balance & -3.1 & -6.3 & -8.4 & -6.8 & -3.4 & -1.8 & -2.8 & -4.3 \\
\hline \multicolumn{9}{|l|}{ Non-OECD countries } \\
\hline \multicolumn{9}{|l|}{ Argentina } \\
\hline Potential real GDP growth $(\%)$ * & 4.0 & 5.0 & 4.9 & 3.8 & 3.2 & 2.6 & 2.4 & 2.1 \\
\hline Total national saving & 20.3 & 25.0 & 19.1 & 19.8 & 18.3 & 17.3 & 15.8 & 14.3 \\
\hline Total investment & 18.2 & 22.0 & 20.8 & 20.0 & 17.5 & 14.9 & 13.8 & 12.4 \\
\hline Current balance & 3.1 & 0.8 & 0.4 & -0.2 & 0.3 & 1.8 & 1.4 & 1.3 \\
\hline \multicolumn{9}{|l|}{ Brazil } \\
\hline Potential real GDP growth (\%) & 3.1 & 4.2 & 4.5 & 4.4 & 3.9 & 2.8 & 2.3 & 1.1 \\
\hline Total national saving & 16.1 & 17.5 & 16.7 & 16.2 & 13.7 & 11.5 & 8.7 & 6.1 \\
\hline Total investment & 16.4 & 19.5 & 20.3 & 19.4 & 16.9 & 13.6 & 12.0 & 9.2 \\
\hline Current balance & 0.7 & -2.2 & -3.2 & -3.4 & -3.6 & -2.5 & -3.7 & -3.5 \\
\hline \multicolumn{9}{|l|}{ China } \\
\hline Potential real GDP growth (\%) & 10.0 & 10.2 & 9.5 & 7.2 & 4.3 & 3.5 & 2.0 & 1.5 \\
\hline Total national saving & 44.6 & 51.8 & 50.1 & 37.9 & 27.2 & 19.2 & 16.2 & 10.2 \\
\hline Total investment & 40.1 & 47.8 & 48.3 & 39.7 & 27.4 & 22.3 & 16.4 & 13.9 \\
\hline Current balance & 4.6 & 4.0 & 1.7 & -1.8 & -0.3 & -3.2 & -0.2 & -3.7 \\
\hline \multicolumn{9}{|l|}{ Indonesia } \\
\hline Potential real GDP growth (\%) & 3.9 & 5.7 & 6.0 & 5.8 & 4.9 & 4.1 & 3.8 & 2.6 \\
\hline Total national saving & 24.6 & 32.1 & 34.6 & 30.4 & 24.3 & 20.3 & 16.4 & 13.1 \\
\hline Total investment & 21.7 & 32.1 & 33.6 & 33.3 & 28.9 & 24.5 & 22.7 & 18.2 \\
\hline Current balance & 2.8 & 0.7 & -1.3 & -3.5 & -5.1 & -4.9 & -7.0 & -5.9 \\
\hline \multicolumn{9}{|l|}{ India } \\
\hline Potential real GDP growth (\%) & 7.4 & 7.8 & 7.3 & 7.1 & 6.1 & 4.8 & 3.8 & 3.0 \\
\hline Total national saving & 29.6 & 31.8 & 28.3 & 27.6 & 23.2 & 21.9 & 20.4 & 17.9 \\
\hline Total investment & 27.1 & 31.1 & 28.4 & 27.8 & 24.3 & 20.0 & 17.2 & 14.8 \\
\hline Current balance & 0.0 & -3.2 & -2.9 & -3.1 & -4.0 & -1.0 & 0.2 & 0.2 \\
\hline \multicolumn{9}{|l|}{ Russia } \\
\hline Potential real GDP growth (\%) & 5.3 & 4.3 & 4.1 & 3.2 & 2.7 & 0.9 & 1.5 & 2.7 \\
\hline \multicolumn{9}{|l|}{ Saudi Arabia } \\
\hline Potential real GDP growth (\%) & 4.2 & 4.6 & 4.6 & 4.7 & 4.0 & 3.2 & 2.5 & 1.7 \\
\hline South Africa & & & & & & & & \\
\hline Potential real GDP growth (\%) & 3.4 & 3.7 & 4.1 & 4.1 & 3.9 & 3.1 & 2.5 & 2.1 \\
\hline Total national saving & 15.0 & 16.6 & 17.7 & 12.7 & 10.2 & 11.2 & 12.0 & 11.8 \\
\hline Total investment & 16.4 & 19.6 & 19.9 & 18.6 & 16.8 & 13.9 & 12.2 & 10.7 \\
\hline Current balance & -2.3 & -2.8 & -5.2 & -7.2 & -7.6 & -3.6 & -1.1 & 0.1 \\
\hline
\end{tabular}

* Avg 2003-2007 


\section{REFERENCES}

Aaronson, D., B. Mazumder and S. Schechter (2010), "What is Behind the Rise in Long-Term Unemployment?", Economic Perspectives, Vol. 34, No. 2, pp. 28-51.

Aghion, P. and P. Howitt (2009), The Economics of Growth, MIT Press, Cambridge, Mass.

Alesina, A., S. Ardagna, G. Nicoletti and F. Schiantarelli (2005), "Regulation and Investment", Journal of the European Economic Association, Vol. 3, No. 4, pp. 791-825.

Andrews, D. and A. de Serres (2012), "Intangible Assets, Resource Allocation and Growth: A Framework for Analysis", OECD Economics Department Working Papers, No. 989.

Bassanini, A. and R. Duval (2006), "Employment Patterns in OECD Countries: Reassessing the Role of Policies and Institutions", OECD Economics Department Working Papers, No. 486.

Beffy, P., P. Ollivaud, P. Richardson and F. Sédillot (2006), "New OECD Methods for Supply-side and Medium-term Assessments: A Capital Services Approach", OECD Economics Department Working Papers, No. 482.

Bernanke, B.S. (2005), “The Global Saving Glut and the US Current Account Deficit”, Remarks delivered at the Sandridge Lecture, Virginia Association of Economics, Richmond, Virginia, March.

Bloom, D.E., D. Canning and J. Sevilla (2003), The Demographic Dividend: A New Perspective on the Economic Consequences of Population Change, RAND.

Bloom, N., M. Draca and J. Van Reenen (2009), "Trade Induced Technical Change? The Impact of Chinese Imports on Innovation and Information Technology”, CEP Discussion Papers, No. 1000.

Bouis, R., R. Duval and F. Murtin (2011), "The Policy and Institutional Drivers of Economic Growth Across OECD and Non-OECD Economies: New Evidence from Growth Regressions", $O E C D$ Economics Department Working Papers, No. 843.

Bourlès, R., G. Cette, J. Lopez, J. Mairesse and G. Nicoletti (2010), "Do Product Market Regulations in Upstream Sectors Curb Productivity Growth?: Panel Data Evidence for OECD Countries", OECD Economics Department Working Papers, No. 791.

Bourguignon, F. and C. Morrisson (2002), "Inequality Among World Citizens: 1820-1992," American Economic Review, Vol. 92, No. 4, pp. 727-744.

Bourguignon, F and T. Verdier (2005), "The Political Economy of Education and Development in an Open Economy", Review of International Economics, Vol. 13, No. 3.

Burniaux, J., R. Duval and F. Jaumotte (2004), "Coping with Ageing: A Dynamic Approach to Quantify the Impact of Alternative Policy Options on Future Labour Supply in OECD Countries", OECD Economics Department Working Papers, No. 371. 
Cecchetti, S., M. Mohanty and F. Zampolli (2011), "The Real Effects of Debt", BIS Working Paper, No. 352.

Chesnais, J.C. (1986), La Transition démographique : étapes, formes, implications économiques, Presses universitaires de France, Paris.

Chiappori, P.A. (1988), "Rational Household Labor Supply", Econometrica, Vol. 56, No. 1, pp. 63-89.

de Serres, A., F. Murtin and C. De la Maisonneuve (2012), "Policies to Facilitate the Return to Work", Comparative Economic Studies, Vol. 54, pp. 5-42.

Duval, R. and C. de la Maisonneuve (2010), "Long-Run Growth Scenarios for the World Economy" Journal of Policy Modeling, Elsevier, Vol. 32, No. 1, pp. 64-80.

Duval, R., M. Eris and D. Furceri (2011), "The Effects of Downturns on Labour Force Participation: Evidence and Causes", OECD Economics Department Working Papers, No. 875.

Easterly, W. and R. Levine (2001), "It's not Factor Accumulation: Stylized Facts and Growth Models", World Bank Economic Review, Vol. 15, No. 2, pp. 177-219.

Égert, B. (2009), "Infrastructure Investment in Network industries: The Role of Incentive Regulation and Regulatory Independence", OECD Economics Department Working Papers, No. 688.

Égert, B. (2010), "Fiscal Policy Reaction to the Cycle in the OECD: Pro- or Counter-Cyclical?", OECD Economics Department Working Papers, No. 763.

Elmeskov, J. and D. Sutherland (2012), "Post-Crisis Debt Overhang: Growth Implications Across Countries", paper prepared for the Reserve Bank of India's Second International Research Conference 2012, 1-2 February, Mumbai, India.

Fouré, J., A. Bénassy-Quéré and L. Fontagné (2010), "The World Economy in 2050: A Tentative Picture", CEPII Working Papers, No. 2010-27.

Fouré, J, A. Bénassy-Quéré and L. Fontagné (2012), "The Great Shift: Macroeconomic Projections for the World Economy at the 2050 Horizon", CEPII Working Papers, No. $2012-03$.

Frankel, J. (2006), “The Balassa-Samuelson Relationship and the Renminbi”, Harvard Working Paper, December.

Galor, O. and D.N. Weil (1996), "The Gender Gap, Fertility, and Growth”, American Economic Review, Vol. 86, No. 3, pp. 374-387.

Girouard, N. and C. André (2005), "Measuring Cyclically-Adjusted Budget Balances for OECD Countries", OECD Economics Department Working Papers, No. 434.

Griffith, R., S. Redding and J. van Reenen (2004), "Mapping the Two Faces of R\&D: Productivity Growth in a Panel of OECD Countries", The Review of Economics and Statistics, Vol. 86, No. 4, pp. 883895.

Hall, R. and C. Jones (1999), "Why Do Some Countries Produce So Much More Output than Others?", Quarterly Journal of Economics, Vol. 114, No. 1, pp. 83-116. 
Hanushek, E.A. and L. Woessmann (2010), The High Cost of Low Educational Performance: The LongRun Impact of Improving PISA Outcomes, OECD Publishing, Paris.

Haugh, D., P. Ollivaud and D. Turner (2009), "The Macroeconomic Consequences of Banking Crises in OECD Countries”, OECD Economics Department Working Papers, No. 683.

Hoshi, T. and T. Ito (2012), "Defying Gravity: How Long Will Japanese Government Bond Prices Remain High?”, NBER Working Papers, No. 18287.

IEA (International Energy Agency) (2011), World Energy Outlook 2011, OECD/IEA, Paris.

IMF (2012), "World Economic Outlook: Growth Resuming, Dangers Remain", World Economic and Financial Surveys, April 2012, International Monetary Fund, Washington, D.C.

Joumard, I., C. André and C. Nicq (2010), "Health Care Systems: Efficiency and Institutions", OECD Economics Department Working Papers, No. 769.

Kerdrain, C., I. Koske and I. Wanner (2010), “The Impact of Structural Policies on Saving Investment and Current Accounts", OECD Economics Department Working Papers, No. 815.

Kumar, M. S. and J. Woo (2010), "Public Debt and Growth”, IMF Working Papers, No. 10/174.

Laubach, T. (2009), "New Evidence on the Interest Rate Effects of Budget Deficits and Debt", Journal of the European Economic Association, Vol. 7, No. 4, pp. 858-885.

Layard, R., S. Nickell and R. Jackman (2009), Unemployment: Macroeconomic Performance and the Labour Market, Oxford University Press.

Leamer, E.E. and J. Levinsohn (1995), "International Trade Theory: The Evidence", in G. M. Grossman and K. Rogoff (eds.), Handbook of International Economics, North Holland.

Li, H., J. Zhang and J. Zhang (2007), "Effects of Longevity and Dependency Rates on Saving and Growth: Evidence from a Panel of Cross Countries", Journal of Development Economics, Vol. 84, No. 1, pp. 138-154.

Mankiw, N.G., D. Romer and D. Weil (1992), "A Contribution to the Empirics of Economic Growth", Quarterly Journal of Economics, Vol. 107, No. 2, pp. 407-437.

Merola, R. and D. Sutherland (2012), "Fiscal Consolidation: Part 3. Long-Run Projections and Fiscal Gap Calculations", OECD Economics Department Working Papers, No. 934.

Mincer, J. (1974), Schooling, Experience and Earnings, Columbia University Press for National Bureau of Economic Research, New York.

Morrisson, C. and F. Murtin (2009), "The Century of Education”, Journal of Human Capital, Vol. 3, No. 1 , pp. 1-42.

Morrisson, C. and F. Murtin (2010), "The Kuznets Curve of Education: A Global Perspective on Education Inequalities", Centre for the Economics of Education Discussion Papers, No. 116, London School of Economics. 
Murtin, F. (2012), "Long-term Determinants of the Demographic Transition", Review of Economics and Statistics, forthcoming.

Murtin, F., A. de Serres and A. Hijzen (2012), "The Ins and Outs of Unemployment: The Role of Labour Market Institutions", OECD Economics Department Working Papers, forthcoming.

Nelson, R. and E. Phelps (1996), "Investment in Humans, Technological Diffusion and Economic Growth” American Economic Review, Vol. 56, No. 1, pp. 69-75.

Nordhaus, W. (2007), “Alternative Measures of Output in Global Economic-Environmental Models: Purchasing Power Parity or Market Exchange Rates?”, Energy Economics, Vol. 29, No. 3, pp. 349372.

OECD (2003), The Sources of Economic Growth in OECD Countries, OECD Publishing.

OECD (2008a), "Explaining Differences in Hours Worked across OECD Countries", Economic Policy Reforms 2008: Going for Growth, OECD Publishing.

OECD (2008b), Higher Education to 2030, Volume 1, Demography, OECD Publishing.

OECD (2010), Perspectives on Global Development 2010, Shifting Wealth, OECD Publishing.

OECD (2011a), Health Care Systems: Efficiency and Policy Settings, OECD Publishing.

OECD (2011b), International Migration Outlook: SOPEMI 2011, OECD Publishing.

OECD (2011c), Pensions at a Glance 2011: Retirement-Income Systems in OECD and G20 Countries, OECD Publishing.

OECD (2011d), "Persistence of High Unemployment: What Risks? What Policies?". OECD Economic Outlook, No. 89, OECD Publishing.

OECD (2012), OECD Pensions Outlook 2012, OECD Publishing.

Oliveira Martins, J. and C. de la Maisonneuve (2006) "The Drivers of Public Expenditure on Health and Long-Term Care: an Integrated Approach”, OECD Economic Studies, No. 42.

Psacharopoulos, G. and H. Patrinos (2004), "Returns to Investment in Education: a Further Update", Education Economics, Vol. 12, No. 2, pp.111-134.

Rawdanowicz, L. (2012), "Choosing the Pace of Fiscal Consolidation", OECD Economics Department Working Papers, No. 992.

Reinhart, C.M. and K.S. Rogoff (2009), This Time is Different: Eight Centuries of Financial Folly, Princeton University Press.

Reinhart, C.M. and K.S. Rogoff (2010), "Growth in a Time of Debt”, American Economic Review, Vol. 100, No. 2, pp. 573-578.

Rogoff, K. (1996), “The Purchasing Power Parity Puzzle”, Journal of Economic Literature, Vol. 34, No. 2, pp. 647-668. 
Röhn, O. (2010), "New Evidence on the Private Saving Offset and Ricardian Equivalance", $O E C D$ Economics Department Working Papers, No. 762.

Turner, D. and F. Spinelli (2011), "Explaining the Interest-Rate-Growth Differential Underlying Government Debt Dynamics”, OECD Economics Department Working Papers, No. 919.

Van den Berg, G.J. and J.C. van Ours (1996), "Unemployment dynamics and duration dependence", Journal of Labor Economics, Vol. 14, pp. 100-125.

Wilson, D., K. Trivedi, S. Carlson and J. Ursúa (2011), “The BRICs 10 Years On: Halfway Through the Great Transformation", Global Economics Paper, No. 208, Goldman Sachs Global Economics and Strategy Research.

Zuniga E. and M. Molina (2008), "Demographic trends in Mexico: Implications for high-skilled Migration”, Migration Policy Institute, Transatlantic Council on Migration. 


\section{APPENDIX 1. GROWTH MODEL}

60. The supply side of the economy consists of a standard aggregate Cobb-Douglas production function with constant returns to scale featuring physical capital, human capital, labour and Harrod-neutral technical progress according to:

$$
Y_{i t}=K_{i, t}^{\alpha}\left(A_{i t} h_{i t} L_{i t}\right)^{1-\alpha}
$$

where $Y, K, A, h$ and $L$ denote output, physical capital, technical progress, human capital per worker, employment and subscript $t$ and $i$ denote year and country. The share of capital is set equal to $1 / 3$. After some manipulations, GDP and GDP per capita (with Pop denoting population) can be written, respectively, as:

$$
\begin{gathered}
Y_{i t}=\left(K_{i t} / Y_{i t}\right)^{\alpha /(1-\alpha)} A_{i t} h_{i t} L_{i t} \\
Y_{i t} / \operatorname{Pop}_{i t}=\left(K_{i t} / Y_{i t}\right)^{\alpha /(1-\alpha)} A_{i t} h_{i t}\left(L_{i t} / \operatorname{Pop}_{i t}\right)
\end{gathered}
$$

where $K / Y$ refers to the capital-output ratio. Employment is further decomposed into trend population $(P O P)$, trend labour force participation rate $(L F P R)$ and trend unemployment rate $(u)$ according to:

$$
L_{i t}=\operatorname{POP}(15+)_{i t} * \operatorname{LFPR}(15+)_{i t} *\left(1-u_{i t}\right)
$$

61. This decomposition is performed for a base year, and long-run scenarios are then made for the individual components. In this set-up, technical change (multi-factor productivity, $A$ ) is derived from GDP per capita, physical capital stock, human capital stock and employment rate by re-arranging equation (1.2) as follows:

$$
A_{i t}=Y_{i t} /\left(K_{i t} / Y_{i t}\right)^{\alpha /(1-\alpha)} h_{i t} L_{i t}
$$

62. In order to perform the decomposition for a base year and draw scenarios, comparable data are needed across countries. To the largest extent possible, OECD data are used. When these data are not available, external sources, such as IMF's World Economic Outlook (WEO), World Development Indicators (WDI) and national sources, are used. ${ }^{37}$ Some key features of the data are: $i$ ) GDP per capita is computed for each country as the ratio of GDP expressed in constant 2005 PPP USD to population; ii) Productive capital stocks are taken from the OECD productivity database. For countries for which there are no official data on productive stocks, capital stocks are built up from investment series (excluding

37. WEO projections are used for: i) GDP: Argentina, Russian Federation, Saudi Arabia and South Africa; ii) Employment: Argentina, Brazil, China, Indonesia, India, Russian Federation, Saudi Arabia and South Africa; and iii) Investment: Argentina, China, Indonesia, India, Russian Federation, Saudi Arabia, South Africa and Chile. 
residential housing investment) through the perpetual inventory method, assuming a $4 \%$ annual depreciation rate; iii) Human capital stocks are constructed by converting average number of years of schooling across the population aged 25-64 into a human capital stock based on an assumption regarding returns to education (see below for details).

63. Population projections are sourced from Eurostat for European OECD countries while for nonEuropean countries projections are from the United Nations Population Database. Projections assume that in the long term total fertility will approach the replacement-level of 2.1, without necessarily reaching it. Gains in life expectancy are projected to be smaller than those observed recently in both data sets, while differences in life expectancy across gender are assumed to narrow. Finally, the future path of international migration is such that projected levels of net migration are generally kept constant over the next decades in both datasets. Although, after 2050, it is assumed that net migration will gradually decline. 


\section{APPENDIX 2. LABOUR FORCE PARTICIPATION}

\section{Calculation of trend labour force participation}

64. The labour force participation scenario is obtained in two steps. First, trend participation is estimated and second, based on trend participation, the long-run scenario until 2060 is drawn. For 34 countries for which cohort-specific participation are available from Labour Force Statistics, trend labour force participation is obtained by aggregating trend age and gender-specific labour force participation for 34 countries using data from the period 1970-2010. For each gender and age group, actual labour force participation is regressed on the aggregate unemployment gap -- which is intended to capture cyclical effects -- on lagged participation and time trends. Second, trend participation by age group is predicted by setting the unemployment gap to zero (i.e. eliminating the influence of the cycle on participation) in the estimated equation. Aggregate trend participation rate is obtained by summing up age and gender-specific trend participation weighted by population weights.

65. More specifically, the following panel model of participation is estimated for each gender-age group $k$ (and for the population older than 15):

$$
l f p_{i, t}^{k}=f_{i}^{k}(t)+\rho^{k} l f p_{i, t-1}^{k}+\lambda_{i}^{k} u n r_{-} g a p_{i, t}+\varepsilon_{i, t}^{k}
$$

where lfp refers to labour force participation, $f$ is a continuous piecewise linear function of time with country-specific intercept and slopes changing values every decade (i.e. 1970-1980, 1980-1990, 1990-2000 and 2000-2010), unr_gap is the unemployment gap taken from OECD Economic Outlook No. 90 and $\varepsilon$ is an error term. Indices $i$ and $t$ indicates country and time. The panel regressions yield significant unemployment gaps with the expected sign for a majority number of countries. Figure A2.1 displays the resulting trend participation for a selected set of countries.

66. Starting from trend participation in 2013, the baseline labour force participation scenario is constructed using a cohort approach for 34 OECD countries. For the remaining countries -- non-OECD G20 -- for which no data on labour force by cohort is available, a simplified approach is used to proxy for the cohort-approach. In short, labour force participation is regressed on population groups and past participation, and this model is used in a second step to draw future scenarios for participation. 
Figure A2.1. Trend labour force participation: selected countries

Per cent
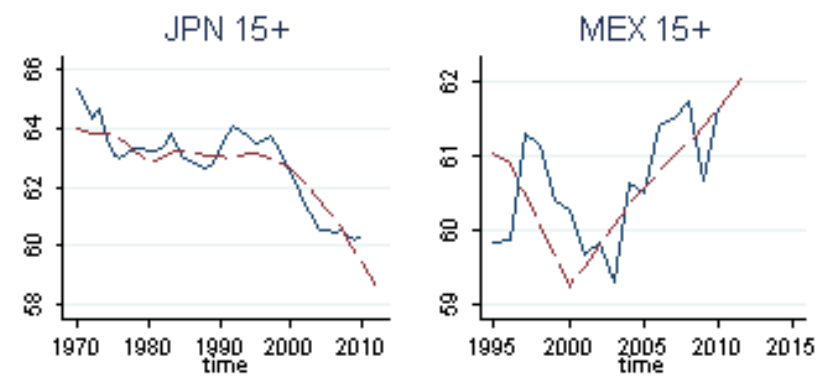

TUR 15+
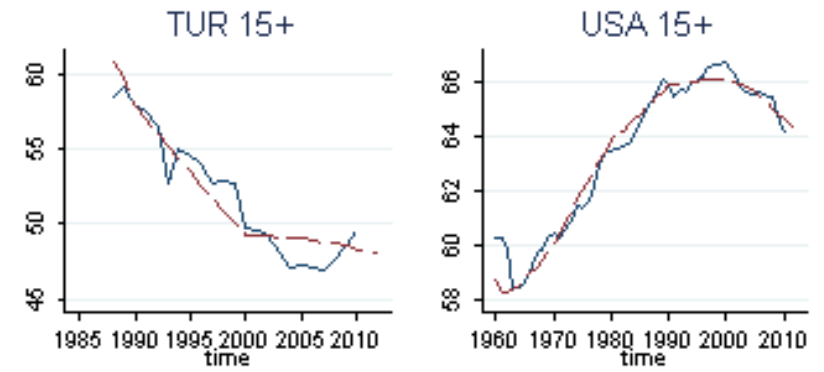

Source: OECD calculations based on Labour Force statistics and OECD Economic Outlook No.90.

\section{Calculation of entry and exit rates into/from the labour force in the cohort approach}

67. Let indices $k, g, t$ represent respectively the age, gender and time dimensions. In each country, labour force participation, the entry and exit rates are denoted respectively $l f p_{k, g, t}, e_{k, g, t}, x_{k, g, t}$. The maximal labour force participation rate is $p_{\max }=0.99$. The formulas used to calculate entry and exit rates are the following:

$$
\begin{aligned}
& x_{k, g, t}=1-\frac{l f p_{k, g, t}}{l f p_{k-1, g, t-1}}, k \geq 2 \\
& x_{1, g, t}=0 \\
& e_{k, g, t}=1-\frac{p_{\max }-l f p_{k, g, t}}{p_{\max }-l f p_{k-1, g, t-1}}, k \geq 2 \\
& e_{1, g, t}=l f p_{1, g, t}
\end{aligned}
$$

Then, various simulations are conducted while assuming constant entry and exit rates (benchmark) or timevarying ones (baseline) in which the exit and entry rates depend on educational attainment. In the case of the convergence scenario towards the frontier country (Switzerland), the law of motion of entry and exit rates in country $i$ is given by:

$$
\begin{aligned}
& x_{k, g, t}^{i}=(1-\lambda) x_{k, g, t}^{C H E}+\lambda x_{k, g, t-1}^{i} \\
& e_{k, g, t}^{i}=(1-\lambda) e_{k, g, t}^{C H E}+\lambda e_{k, g, t-1}^{i}
\end{aligned}
$$




\section{APPENDIX 3. DEFINITION AND CALCULATION OF ACTIVE LIFE EXPECTANCY}

68. Active life expectancy is a counterfactual construction that reflects the average number of years that a hypothetical worker would spend in the labour force if he/she would face the same entry, exit and participation rates observed today along his/her entire active life. The calculation of active life expectancy relies on the age and gender-specific probabilities of entering and exiting to/from the labour force and the accompanying participation rates. It is similar to the calculation of life expectancy, which represents the average lifetime of a hypothetical person facing currently observed mortality rates.

69. More specifically, in each period of time $t$, a fictitious duration of active life can be computed. This duration relies on the entry and exit rates of each cohort of age observed at the same date, which are used to calculate the average active life that a fictitious cohort would receive if it displayed the same entry and exit rates along its life cycle. An identical procedure is used to calculate life expectancy in demography, therefore the outcome of this calculation is labeled as "active life expectancy". The active life expectancy can be calculated in a recursive way as shown below.

70. Let $T(k)$ be the number of years so far spent in the labour force at age $k$, and let $\mathrm{k}$ take discrete values $(15,20,25 \ldots 60,65,70,75)$. In each period $t$, a worker aged $k$ can decide to enter or exit the labour force with probabilities $\left(e_{k, t}, x_{k, t}\right)$. If she enters or exits the labour force, she does so for a period of five years. Her participation rate is denoted $l f p_{k, t}$. A recursive calculation of $T(k)$ is given by the following equality:

$$
T(k+1)=T(k)+5\left[l f p_{k} \cdot\left(1-x_{k+1}\right)+\left(1-l f p_{k}\right) \cdot e_{k+1}\right]
$$

which states that the number of years spent in the labour force at age $k$ is increased by five years if a worker remains in the labour force or quits inactivity and enters the labour force. With $T(1)=0$ one obtains the definition of active life expectancy:

$$
T_{\infty}=5 \cdot \sum_{1}^{\infty}\left[l f p_{k} \cdot\left(1-x_{k+1}\right)+\left(1-l f p_{k}\right) \cdot e_{k+1}\right]
$$

71. The above definition offers a convenient alternative aggregate statistics to the participation rate of the population aged 15+. Interestingly, it is not affected by composition effects of the labour force (i.e. it is not sensitive to differences in age pyramids). 
ECO/WKP(2012)77

\section{APPENDIX 4. PROMOTING LABOUR FORCE PARTICIPATION}

\section{Fostering old-age participation}

72. Based on a panel of 22 countries observed between 1975 and the early 2000s (see Table A4.1), three significant determinants of exit rates out of the labour force at the age of 60-64 years have been identified, namely the survival probability between age 60 and 64 years (a proxy for health status), the implicit tax on continued work (Duval et al., 2011) and the legal pension age for getting full-rate retirement (the so-called 'pensionable age'). The findings drawn from the empirical analysis suggest that:

- Fiscal incentives to continue working at older age have a sizeable influence on the exit rate, implying that countries with disproportionately high implicit tax rates (over 50\%) on continued work such as Greece, Slovenia, Luxembourg and Hungary could significantly reduce the exit rate by reforming old-age retirement systems.

- The influence of the legal age of retirement is large and suggests that countries such as Belgium, France, Greece, Italy and most Continental and Eastern European countries could foster participation at older age by raising the legal age of retirement (see OECD, 2011c). One possible way of implementing this reform, while also reducing the political cost of renegotiation, would be to partly index the legal age on life expectancy at birth or at age 60 or 65 as currently done in Italy and Denmark.

- The extension of labour force participation at older age is conditional on the health status of older workers, which confers a pay-off to efficient health policies (Joumard et al., 2010). Put differently, there is scope for significantly expanding old-age participation in countries where life expectancy at age 60 is high, such as in France, Austria, Luxembourg, Belgium, Denmark, Germany and Italy, as on average older workers are presumably in good health in those countries.

- There is large scope for improvement among female workers. In 2010, the pensionable age was on average one year lower for females, who also displayed higher life expectancy at age 60 than males (equal to 25 years on average versus 20 years for males). 
Table A4.1. Determinants of old-age exit rates out of the labour force: Panel results

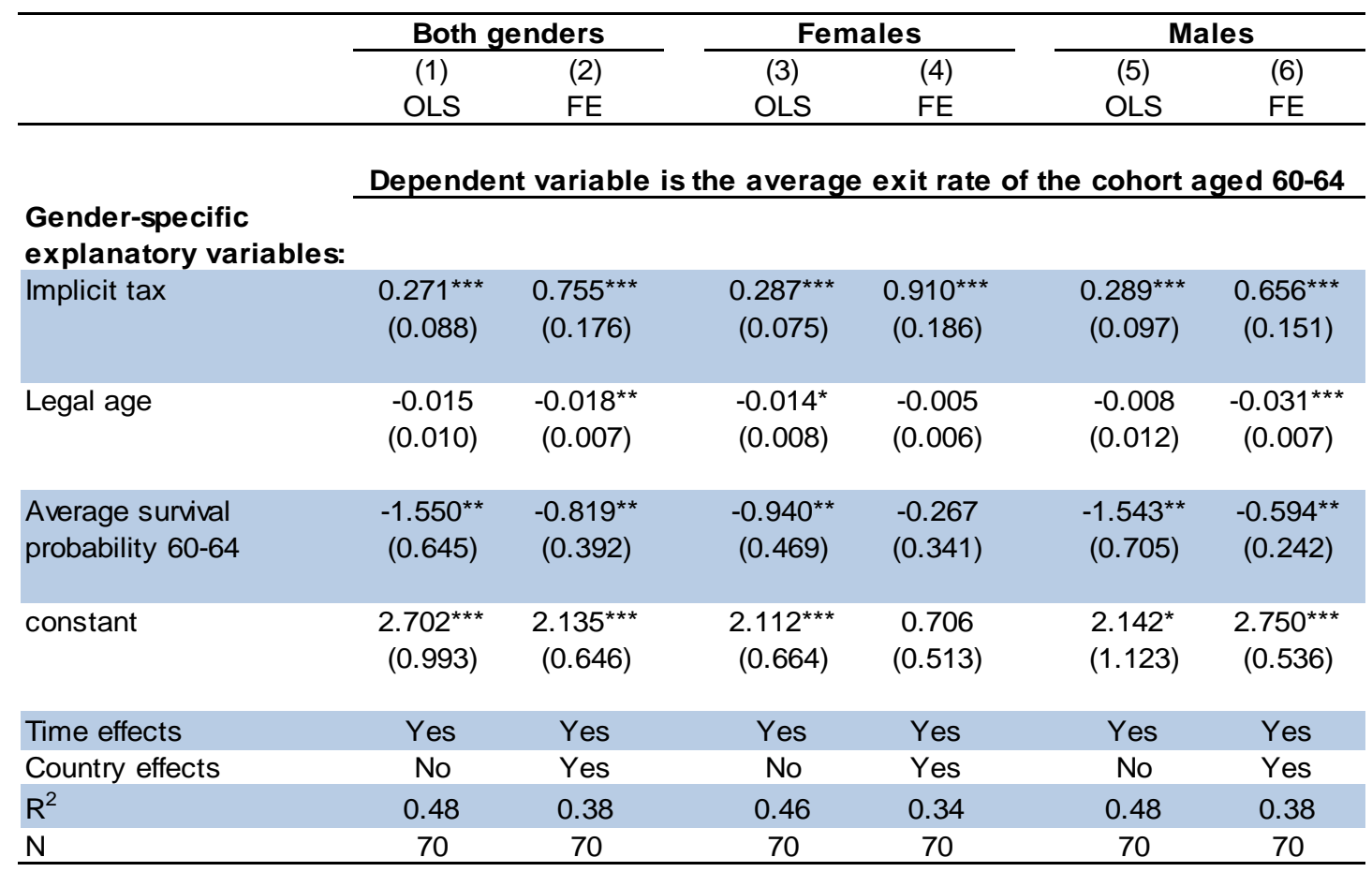

\section{Immigration has little impact on labour force participation}

73. Net migration could potentially increase aggregate participation among the population older than 15 years. As already mentioned, migrants are to a large extent working-age adults. To be translated into higher aggregate participation, it is sufficient, albeit not necessary, that migrants participate in the labour market as much as the native population. Over the past decade, labour force participation among foreignborn individuals was on average lower than that of natives in European countries, mainly as a consequence of lower participation among foreign-born women. However, in some countries with recent large workrelated inflows of migrants (e.g. Spain, Italy and Portugal), foreign-born migrants display greater participation rates than natives. Projecting the influence of alternative future migration trends on participation, a counterfactual simulation was run in which the inflow of migrants is assumed to be twice as large as the one observed in the past decade, whereas the age structure of migrants is assumed to be same as for natives. Hence, the demographic effect described above is neutralised in this simulation and only differences in participation by age and by gender are considered. This "accelerated migration scenario" has a slightly negative effect on participation in most countries as migrants participate relatively less than natives, although positive effects are found in Spain, Greece, Italy, Luxembourg and Portugal (Figure A4.1). However, projections for Spain, Italy and Portugal are likely to be biased upwards as, over time, family reunification can be expected to lower participation rates for women and offset the current positive effect. 
Figure A4.1. Immigration has limited influence on future labour force participation trends: selected countries ${ }^{1}$

Deviation from baseline labour force participation, percentage points

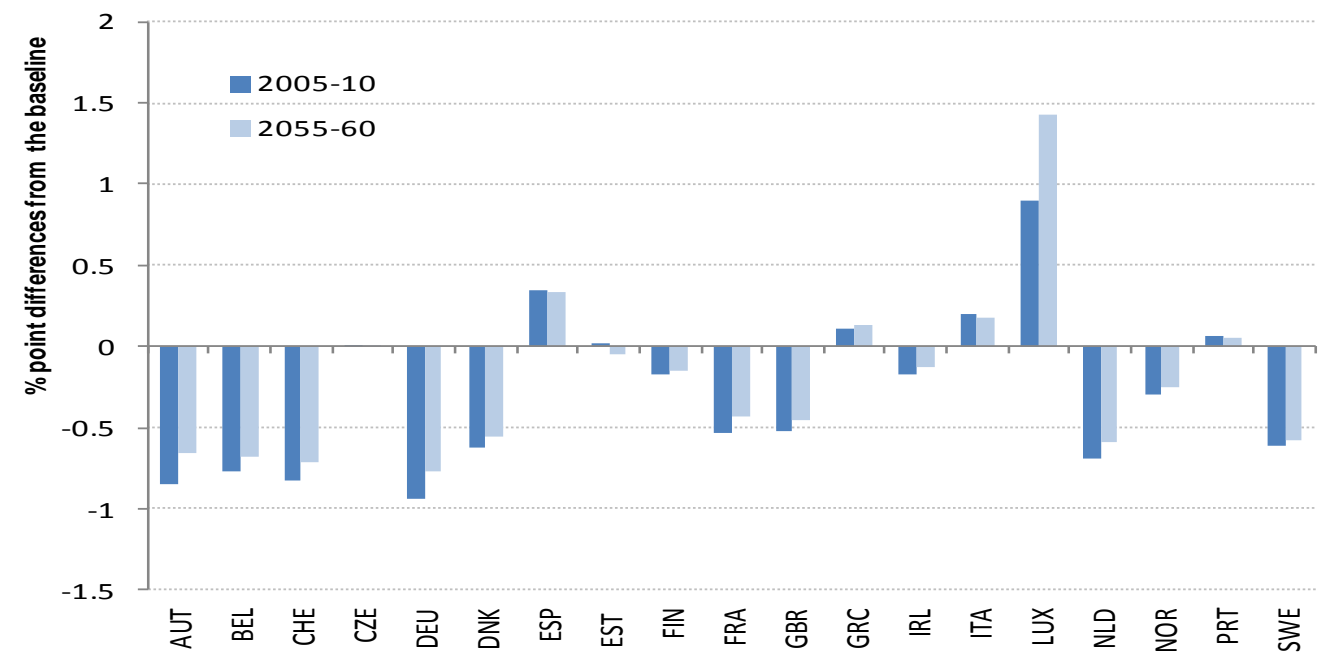

1. The analysis only covers European OECD countries for which data on labour force participation by migrant status are available. The data show average labour force participation rates over five years to match the cohorts which are in five-year intervals.

Source: Eurostat. 


\section{APPENDIX 5. UNEMPLOYMENT}

\section{Baseline scenario}

74. Trend unemployment is assumed to gradually return to pre-crises levels (or long-run levels), where the unemployment path is projected using an estimated panel model (de Serres et al., 2012). This model relates both the unemployment level and persistence to labour market institutions as follows:

$$
\log U_{i, t}=\left(1-\rho\left(X_{i, t}^{\rho}\right)\right) \cdot\left(a_{i}+d_{t}+X_{i, t} \beta\right)+\rho\left(X_{i, t}^{\rho}\right) \log U_{i, t-1}+\sigma\left(X_{i, t}^{\sigma}\right) Z_{i, t}+v_{i, t}
$$

where $U$ is the unemployment rate, $X, X^{\rho}$ and $X^{\sigma}$ are three sets of labour market institutions, $Z$ is a proxy for the business cycle (i.e. the output gap taken from the OECD Economic Outlook), $a_{i}$ are country fixed effects, $d_{t}$ are time fixed effects and $v$ an idiosyncratic residual term. In this specification both the degree of unemployment persistence and cyclical volatility, denoted respectively $\rho\left(X^{\rho}\right)$ and $\sigma\left(X^{\sigma}\right)$, are conditioned by labour market institutions. In particular, this model allows identifying the effect of institutions on the longterm level of unemployment, which is given by:

$$
\left.U^{*}=\exp \left(a_{i}+d_{t}+X_{i, t} \beta\right)\right)
$$

75. For OECD countries, trend unemployment (NAIRU) is taken from the OECD Economic Outlook No. 91 and information on labour market institutions is sourced from various OECD databases. Table A5.1 shows the panel regression results covering 24 countries and spanning 1985-2007. 
ECO/WKP(2012)77

Table A5.1. Panel regression results: Unemployment rate

Table 1 - Labour Market Institutions and Unemployment Dynamics 1985-2007

\begin{tabular}{|c|c|c|c|c|c|c|c|c|}
\hline \multirow{3}{*}{$\begin{array}{l}\text { Dependent variable: } \\
\text { Estimator: } \\
\end{array}$} & \multicolumn{8}{|c|}{ "Log unemployment rate } \\
\hline & OLS & GMM & NLS & NLS & NLS & NLS & NLS & NLS \\
\hline & (1) & (2) & (3) & (4) & (5) & (6) & (7) & (8) \\
\hline & & & Long-tern & Unemplc & yment Le & el Effect & & \\
\hline \multirow[t]{2}{*}{ Initial replacement rate } & $0.600^{\star \star \star}$ & $0.601^{*}$ & $1.580^{\star \star \star}$ & $1.395^{\star \star \star}$ & $1.324^{* \star *}$ & $1.554^{\star \star \star}$ & $1.449^{\star \star \star}$ & $1.470^{\star \star \star}$ \\
\hline & $(0.132)$ & $(0.324)$ & $(0.338)$ & $(0.324)$ & $(0.330)$ & $(0.374)$ & $(0.303)$ & $(0.299)$ \\
\hline \multirow[t]{2}{*}{ Average benefits duration } & -0.132 & -0.196 & -0.290 & -0.228 & $-0.396^{\star}$ & -0.229 & -0.231 & -0.227 \\
\hline & $(0.150)$ & $(0.213)$ & $(0.247)$ & $(0.223)$ & $(0.236)$ & $(0.263)$ & $(0.234)$ & $(0.234)$ \\
\hline \multirow[t]{2}{*}{ ALMPs } & $-0.542^{* \star}$ & -0.301 & $-1.563^{\star \star *}$ & $-1.642^{\star \star \star}$ & $-1.117^{\star \star \star}$ & $-1.421^{\star * \star}$ & $-1.551^{\star * *}$ & $-1.574^{* * *}$ \\
\hline & $(0.242)$ & $(0.281)$ & $(0.297)$ & $(0.304)$ & $(0.320)$ & $(0.309)$ & $(0.310)$ & $(0.305)$ \\
\hline \multirow{2}{*}{ EPL regular contracts } & 0.010 & 0.026 & 0.061 & 0.050 & 0.025 & 0.027 & 0.078 & 0.073 \\
\hline & $(0.026)$ & $(0.050)$ & $(0.067)$ & $(0.060)$ & $(0.072)$ & $(0.066)$ & $(0.071)$ & $(0.070)$ \\
\hline \multirow[t]{2}{*}{ Tax wedge } & $0.011^{\star \star \star}$ & $0.011^{\star \star \star}$ & $0.022^{\star \star \star}$ & $0.028^{\star \star \star}$ & $0.029^{\star \star \star}$ & $0.026^{\star \star \star}$ & $0.026^{\star \star \star}$ & $0.026^{\star \star \star}$ \\
\hline & $(0.003)$ & $(0.004)$ & $(0.006)$ & $(0.005)$ & $(0.005)$ & $(0.005)$ & $(0.005)$ & $(0.005)$ \\
\hline \multirow[t]{2}{*}{ Tax wedge $x$ excess coverage } & $0.043^{\star \star \star}$ & $0.025^{\star \star}$ & $0.094^{\star \star \star}$ & $0.094^{\star \star \star}$ & $0.110^{\star \star \star}$ & $0.107^{\star \star \star}$ & $0.083^{\star \star \star}$ & $0.082^{\star \star \star}$ \\
\hline & $(0.010)$ & $(0.012)$ & $(0.023)$ & $(0.020)$ & $(0.021)$ & $(0.022)$ & $(0.022)$ & $(0.022)$ \\
\hline \multirow[t]{2}{*}{ Excess coverage } & $0.257^{\star \star}$ & 0.048 & $0.594^{\star \star}$ & $0.697^{\star \star \star}$ & $0.658^{\star \star \star}$ & $0.658^{\star \star \star}$ & $0.780^{\star \star \star}$ & $0.773^{\star \star \star}$ \\
\hline & $(0.100)$ & $(0.136)$ & $(0.284)$ & $(0.222)$ & $(0.221)$ & $(0.247)$ & $(0.244)$ & $(0.245)$ \\
\hline \multirow[t]{2}{*}{ Union density } & $0.396^{*}$ & $0.817^{* *}$ & 0.522 & $1.232^{* \star \star}$ & $1.328^{\star \star \star}$ & $0.988^{\star \star}$ & $1.126^{\star \star}$ & $1.063^{\star \star}$ \\
\hline & $(0.209)$ & $(0.415)$ & $(0.522)$ & $(0.426)$ & $(0.453)$ & $(0.458)$ & $(0.489)$ & $(0.484)$ \\
\hline \multirow[t]{3}{*}{ PMR } & 0.009 & 0.034 & 0.036 & 0.015 & 0.034 & 0.022 & 0.036 & 0.035 \\
\hline & $(0.012)$ & $(0.022)$ & $(0.032)$ & $(0.028)$ & $(0.027)$ & $(0.031)$ & $(0.027)$ & $(0.027)$ \\
\hline & \multicolumn{8}{|c|}{ Persistence Effect (logit form) } \\
\hline \multirow{2}{*}{ Constant } & $0.590^{\star \star \star}$ & $0.543^{* \star *}$ & 0.058 & $0.303^{* *}$ & -0.145 & $0.840^{* *}$ & $-0.795^{\star \star *}$ & $-0.761^{\star \star *}$ \\
\hline & $(0.055)$ & $(0.062)$ & $(0.418)$ & $(0.119)$ & $(0.197)$ & $(0.364)$ & $(0.254)$ & $(0.239)$ \\
\hline \multirow[t]{2}{*}{ Initial replacement rate } & & & -0.560 & & & & & \\
\hline & & & $(0.442)$ & & & & & \\
\hline \multirow[t]{2}{*}{ Average benefits duration } & & & $1.209^{* \star *}$ & & & & $1.326^{\star \star \star}$ & $1.339^{\star \star \star}$ \\
\hline & & & $(0.389)$ & & & & $(0.331)$ & $(0.321)$ \\
\hline \multirow[t]{2}{*}{ ALMPs } & & & & 0.146 & & & & \\
\hline & & & & $(0.481)$ & & & & \\
\hline \multirow[t]{2}{*}{ EPL regular contracts } & & & & & $0.236^{* \star *}$ & & $0.202^{\star \star}$ & $0.185^{\star \star}$ \\
\hline & & & & & $(0.085)$ & & $(0.081)$ & $(0.078)$ \\
\hline \multirow[t]{3}{*}{ PMR } & & & & & & -0.124 & & \\
\hline & & & & & & $(0.090)$ & & \\
\hline & & & & atput Gap & Interactio & & & \\
\hline \multirow[t]{2}{*}{ Constant } & $0.045^{\star \star \star}$ & $0.046^{\star \star \star}$ & $0.022^{\star \star}$ & $0.031^{* \star *}$ & $0.054^{\star \star \star}$ & $0.041^{* \star *}$ & $0.045^{\star \star \star}$ & $0.045^{\star \star \star}$ \\
\hline & $(0.003)$ & $(0.005)$ & $(0.011)$ & $(0.004)$ & $(0.006)$ & $(0.009)$ & $(0.012)$ & $(0.007)$ \\
\hline Initial replacement rate & & & $0.022^{*}$ & & & & $-0.032^{*}$ & $-0.036^{\star \star}$ \\
\hline & & & $(0.013)$ & & & & $(0.017)$ & $(0.014)$ \\
\hline Average benefits duration & & & $0.020^{*}$ & & & & 0.002 & \\
\hline & & & $(0.012)$ & & & & $(0.012)$ & \\
\hline ALMPs & & & & $0.119^{\star \star \star}$ & & & $0.152^{\star \star \star}$ & $0.156^{\star * *}$ \\
\hline & & & & $(0.022)$ & & & $(0.027)$ & $(0.025)$ \\
\hline EPL regular contracts & & & & & $-0.004^{*}$ & & -0.001 & \\
\hline & & & & & $(0.002)$ & & $(0.002)$ & \\
\hline PMR & & & & & & 0.001 & & \\
\hline & & & & & & $(0.002)$ & & \\
\hline Time and country fixed-effects & Yes & Yes & Yes & Yes & Yes & Yes & Yes & Yes \\
\hline$R^{2}$ & 0.976 & - & 0.999 & 0.999 & 0.999 & 0.999 & 0.999 & 0.999 \\
\hline $\mathrm{N}$ & 441 & 412 & 441 & 441 & 441 & 441 & 441 & 441 \\
\hline
\end{tabular}

Note: ${ }^{* *}$ denotes statistical significant at $1 \% ;{ }^{* *}$ at $5 \%$ and ${ }^{*}$ at $10 \%$. Robust standard errors in parenthesis. 
76. In a second step, long-run scenarios for trend unemployment (NAIRU) are drawn based on the following dynamics of trend unemployment:

$$
\log N A \operatorname{IR} U_{i, t}=\left(1-\rho\left(X_{i, t}^{\rho}\right)\right) \cdot U_{i}^{*}+\rho\left(X_{i, t}^{\rho}\right) \log N A I R U_{i, t-1}
$$

77. After 2013, the long-term value of trend unemployment has to be chosen. As a benchmark assumption, we use the smallest value between trend unemployment in 2007 and 2013 as the long-term value of the NAIRU. For the large majority of countries that have experienced an increase in trend unemployment during and after the 2008-2009 economic crisis, this scenario implies a gradual return towards pre-crisis levels (Figure A5.1). For other countries, such as Germany, in which trend unemployment has fallen, the NAIRU value in 2013 is kept as a benchmark.

78. For non-OECD countries a different set-up is applied reflecting the fact that trend unemployment is currently comparatively high in some of these countries. Therefore, in countries for which trend unemployment is currently above the average trend unemployment level observed in OECD countries (e.g. Argentina, Brazil, the Russian Federation and South Africa,) it is assumed that unemployment will gradually converge to the average OECD level. While in countries were trend unemployment is below the average OECD level, it is assumed to remain unchanged.

\section{Alternative scenario: reducing trend unemployment}

79. A number of labour market settings and institutions have been found to influence structural unemployment (e.g. Layard et al., 2009). To illustrate the impact of labour reforms on future trend unemployment three stylised policy changes occurring in 2014 is considered, namely: i) a cut in the replacement rate of unemployment benefits by 10 percentage points; ii) a cut in the tax wedge by 4 percentage points ${ }^{38}$ iii) an increase in the volume of Active Labour Market Policies (ALMPs) by one standard deviation. It should be noted that the implications for public budgets and interest rates are not explicitly taken into account in these stylised simulations. However, the tax cut could for example be envisaged to be financed by an increase in a less harmful tax such as recurrent taxes on immovable property. Figure A5.1 shows the resulting unemployment paths for selected countries, the solid line shows the baseline scenario and the dotted lines policy reform scenarios. In line with previous studies, (e.g. Bassanini and Duval, 2006; de Serres et al., 2012), cuts in the tax wedge and in the replacement rate, together with greater spending on ALMPs have a large influence on the long-term level of unemployment. For instance, the tax cut would on average reduce trend unemployment by about 1 percentage point and raise GDP in 2060 by on average 1\%, relative to baseline. In countries with either decentralised or centralised wage bargaining systems, such as those prevailing in the United States or Sweden, the effect of the tax wedge reduction is quite limited (i.e. half a percentage point), whereas it is larger in countries such as France or Spain (i.e. around 2.5 percentage points) that are characterised by intermediate, sector-level, wage bargaining processes. In addition, the level of the replacement rate and spending on ALMPs appear to be two important channels through which public policy may affect the medium-term unemployment rate. It should be noted that the implications for public budgets and interest rates are not explicitly taken into account in these stylised simulations.

38. The latter two figures correspond to half a sample standard deviation of the replacement rate and the tax wedge respectively. 
Figure A5.1. Trend unemployment will gradually return to the pre-crisis level or to lower levels depending on labour market policy reforms: selected countries

Spain

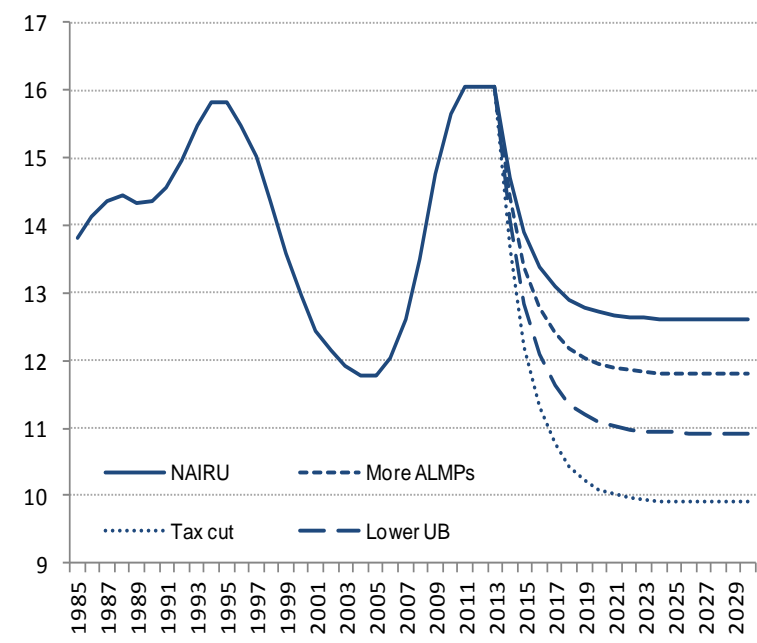

Sweden

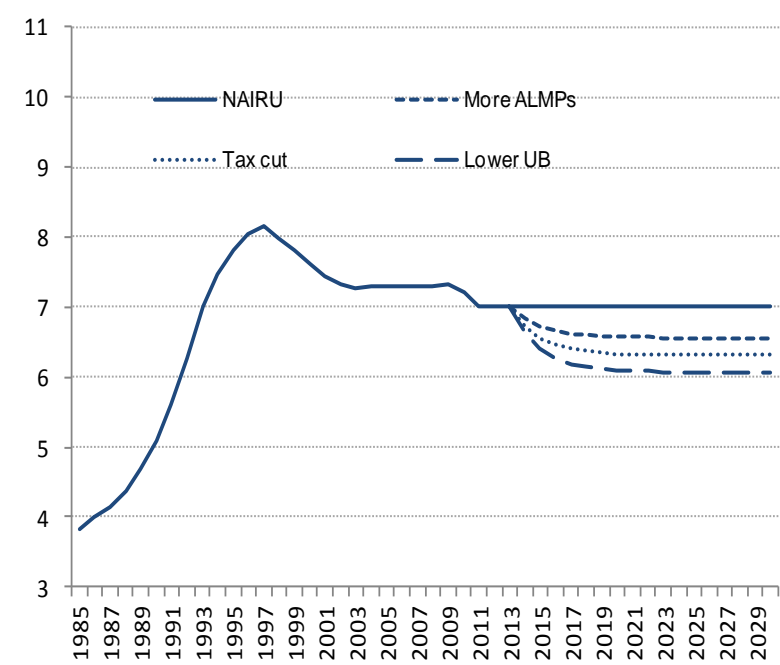

Per cent

France

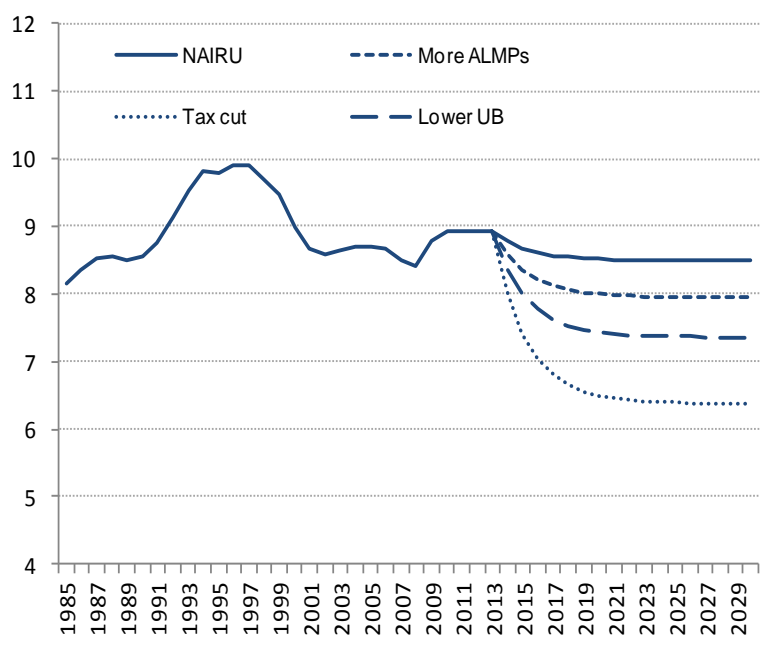

the United States

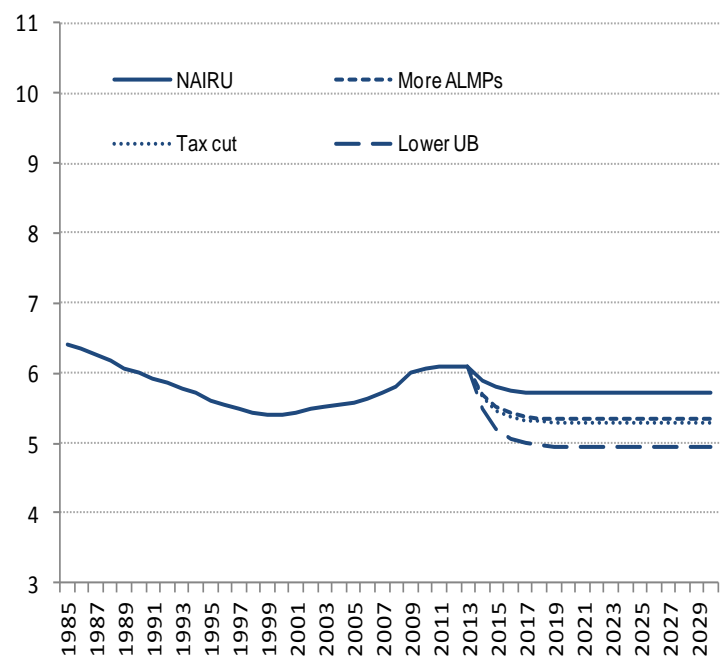




\section{APPENDIX 6. HUMAN CAPITAL}

80. Human capital stocks are constructed in two steps. In a first step, data on the average number of years of schooling across the population aged 25-64 are assembled using the Bouis et al. (2011) dataset. In a second step, the average number of years of schooling across the population is converted into a human capital stock based on an assumption regarding returns to education. More specifically, human capital per worker is given by:

$$
h_{t}=e^{r(S)}
$$

where $s$ denotes the number of years of schooling and $r$ returns to schooling. While the magnitude of social returns to education -- and of possible externalities to education -- remains subject to uncertainty, generally studies tend to rely on falling marginal returns at higher levels of education (years of schooling) (e.g. Hall and Jones, 1999; Psacharopoulos and Patrinos, 2004). Indeed, relying on microeconomic evidence on returns to schooling for a large set of countries, Morrison and Murtin (2010) estimates the returns $r$ to years of schooling $s$ to be $r=0.125-0.004 s$.

81. The baseline human capital scenario assumes that over time each age-cohort keeps the level of schooling obtained between ages of 25-29 years, which implies assuming equal mortality across educational groups. Reflecting past trends, the baseline assumes that educational attainment of the 25-29 age group continues to gradually improve until it reaches 18 years of schooling -- which is equal to 12 years of primary and secondary, 4 years of university and 2 years of post-graduate studies -- in 2100 . The speed of convergence is identical across countries and it is based on the observed cross-country convergence over 1960-2005 - equal to $1 \%$ per year. This speed of convergence is low as even the leader country Korea in 2011, falls short of reaching the frontier of 18 years in 2100 (it reaches 17.2 years). Based on this scenario for the 25-29 old age group, future educational attainment of the population is projected through cohort effects to take demographics into account. 


\section{APPENDIX 7. MULTI-FACTOR PRODUCTIVITY}

82. The empirical specification underlying MFP convergence process draws on recent work by Bourlès et al. (2010) and Bouis et al. (2011). It accounts for the effect of international spillovers and competitive policies by explicitly allowing productivity to depend on product market regulation, whilst the speed of convergence towards the world frontier to depend on openness. More specifically, MFP dynamics is governed by an error-correction model:

$$
\begin{aligned}
& \Delta a_{i, t}=\rho_{i, t}^{a}\left(a_{i, t}^{*}-a_{i, t-1}\right) \\
& a_{i, t}^{*}=\partial_{i}+g_{t}+P M R_{i, t} \beta \\
& \rho_{i, t}^{a}=h\left(O_{i, t}\right)
\end{aligned}
$$

where $a_{i t}=\log A_{i t}$ and $i$, and $t$ indicates country and time; $a^{*}$ is the long-run MFP level which is given an exogenous long-term growth rate $g$ common to all countries which corresponds to the pace of the world technological frontier and is captured by time dummies $d t$. Product market regulation (PMR) affects the level of MFP, while openness $O$ affects the country-specific speed of convergence $\rho$ towards the long-term level of MFP. Over the long run, the level of MFP differs across countries, but the growth rate of productivity is the same, provided policies and other institutional settings are kept constant. Panel regression covering most of the countries included in the study over the period 1998-2008 are reported in Table A7.1.

Table A7.1. Panel results: MFP convergence

\begin{tabular}{lcc}
\multicolumn{1}{c}{ Dependent variable: Multi-factor productivity } & \\
\hline & Baseline & Including hours \\
Speed of catch-up & $0.065^{\star \star}$ & $0.085^{\star \star \star}$ \\
Speed of catch-up*openness & $(0.03)$ & $(0.03)$ \\
\hline Product market regulation & $0.043^{*}$ & $0.084^{\star *}$ \\
Time fixed effects & $(0.02)$ & $(0.04)$ \\
Country fixed effects in long-run productivity level & $-0.434^{* *}$ & $-0.326^{*}$ \\
Observations & $(0.21)$ & $(0.17)$ \\
\hline
\end{tabular}

Note: ${ }^{* *}$ denotes statistical significant at $1 \% ;{ }^{* *}$ at $5 \%$ and ${ }^{*}$ at $10 \%$. Robust standard errors in parenthesis.

83. One driver of the convergence process, and future productivity, is the development of openness. The amount of trade between countries is likely to be increasing in domestic and trading partners' income (or income per capita) reflecting that as countries becomes wealthier they trade more. Conversely, all else equal, larger countries are likely to trade less as they have access to a larger domestic market. Transportation costs and other costs or barriers to trade potentially reduce the amount of trade (e.g. Leamer 
and Levinsohn, 1995). Consistent with this, future openness is modelled as a reduced-form equation depending on domestic income, income of trading partners, population, competitiveness of countries (e.g. real exchange rate) and policy barriers to trade (e.g. PMR barriers to trade). The following panel model is estimated over the period 1998-2008 covering 39 countries (see Table A7.2):

$$
o_{i, t}=\alpha+\delta_{1} o_{i, t-1}+\delta_{2} y_{i, t-1}+\delta_{3} y_{i, t-1}^{*}+\delta_{4} \text { pop }_{i, t-1}+\delta_{5} R E E R_{, t-1}+\delta_{6} T_{i, t-1}+\eta_{i}+d_{t}+\varepsilon_{i, t}
$$

where $o, y, y^{*}$, pop, REER and $T$ refer to log of openness (exports plus imports as a share of GDP), log of domestic income, log of trade weighed income of trading partners, log of population, log of real effective exchange rate and PMR trade regulations. $i$ denotes country, $t$ year, $\eta$ country-fixed effects and $d_{t}$ time fixed effects. To allow for non-linear or threshold effects of income and population on openness, the impact of these variables is allowed to differ, respectively, between high and low income countries and large and small countries in terms of population.

Table A7.2. Panel results: openness

\begin{tabular}{|c|c|c|}
\hline \multicolumn{3}{|c|}{ Dependent variable: log openness } \\
\hline Lagged openness & $\begin{array}{c}0.505^{\star \star \star} \\
(0.06)\end{array}$ & $\begin{array}{c}0.522^{* \star *} \\
(0.06)\end{array}$ \\
\hline GDP per capita, low (t-1) & $\begin{array}{l}0.129 \\
(0.12)\end{array}$ & \\
\hline GDP per capita, high (t-1) & $\begin{array}{l}-0.067 \\
(0.11)\end{array}$ & \\
\hline Trade weighted GDP per capita partner, low (t-1) & $\begin{array}{l}1.397^{* *} \\
(0.66)\end{array}$ & $\begin{array}{l}1.333^{*} \\
(0.67)\end{array}$ \\
\hline Trade weighted GDP per capita partner, high (t-1) & $\begin{array}{l}0.833 \\
(0.64)\end{array}$ & $\begin{array}{l}0.806 \\
(0.67)\end{array}$ \\
\hline Population, low & $\begin{array}{c}-0.546^{* *} \\
(0.22)\end{array}$ & $\begin{array}{c}-0.466^{\star} \\
(0.25)\end{array}$ \\
\hline Population, high & $\begin{array}{c}-0.843^{\star *} \\
(0.33)\end{array}$ & $\begin{array}{c}-0.788^{* *} \\
(0.33)\end{array}$ \\
\hline Trade regulations (PMR trade) & $\begin{array}{c}-0.043^{* * *} \\
(0.01)\end{array}$ & $\begin{array}{c}-0.046^{\star * *} \\
(0.01)\end{array}$ \\
\hline Real effective exchange rate & $\begin{array}{c}-0.351^{* * *} \\
(0.07)\end{array}$ & $\begin{array}{c}-0.355^{\star * \star} \\
(0.05) \\
\end{array}$ \\
\hline Observations & 338 & 338 \\
\hline Time and fixed effects & Yes & Yes \\
\hline
\end{tabular}

Note: ${ }^{* * *}$ denotes statistical significant at $1 \% ;{ }^{* *}$ at $5 \%$ and ${ }^{*}$ at $10 \%$. Robust standard errors in parenthesis.

Thresholds are: "GDP per capita, low" refers to below 13000 USD PPP, "Trade weighted GDP per capita, low" refers to below 18000 USD PPP and "Population, low" refers to below 25 million inhabitants.

84. In the future scenario for openness, a corollary assumption, assuming that purchasing power parity holds in the long run, is that the trade weighted real effective exchange rate slowly converge towards 1 over the projection period. 
ECO/WKP(2012)77

APPENDIX 8. DETAILED PROJECTION TABLES

Table A8.1. Average growth rate in trend GDP and trend GDP per capita in USD 2005 PPPs

\begin{tabular}{|c|c|c|c|c|c|c|c|c|}
\hline & \multicolumn{4}{|c|}{ Average growth in GDP in USD 2005 PPPs } & \multicolumn{4}{|c|}{ Average growth in GDP per capita in USD 2005 PPPs } \\
\hline & $1995-2011^{1}$ & $2011-2030$ & $2030-2060$ & 2011-2060 & $1995-2011^{1}$ & $2011-2030$ & $2030-2060$ & 2011-2060 \\
\hline Australia & 3.3 & 3.1 & 2.2 & 2.6 & 1.9 & 2.0 & 1.7 & 1.8 \\
\hline Austria & 2.0 & 1.5 & 1.4 & 1.4 & 1.7 & 1.2 & 1.4 & 1.3 \\
\hline Belgium & 1.8 & 2.1 & 2.0 & 2.0 & 1.3 & 1.5 & 1.7 & 1.6 \\
\hline Canada & 2.6 & 2.1 & 2.3 & 2.2 & 1.6 & 1.3 & 1.8 & 1.6 \\
\hline Switzerland & 1.7 & 2.2 & 2.0 & 2.1 & 1.0 & 1.5 & 1.8 & 1.7 \\
\hline Chile & 3.9 & 4.0 & 2.0 & 2.8 & 2.8 & 3.4 & 2.0 & 2.5 \\
\hline Czech Republic & 3.2 & 2.7 & 1.8 & 2.1 & 3.1 & 2.6 & 1.9 & 2.2 \\
\hline Germany & 1.4 & 1.3 & 1.0 & 1.1 & 1.4 & 1.5 & 1.5 & 1.5 \\
\hline Denmark & 1.5 & 1.3 & 2.1 & 1.8 & 1.1 & 1.0 & 2.0 & 1.6 \\
\hline Spain & 2.9 & 2.0 & 1.4 & 1.7 & 1.9 & 1.6 & 1.3 & 1.4 \\
\hline Estonia & 3.6 & 2.8 & 2.0 & 2.4 & 3.8 & 3.1 & 2.3 & 2.6 \\
\hline Finland & 2.5 & 2.1 & 1.6 & 1.8 & 2.2 & 1.8 & 1.5 & 1.6 \\
\hline France & 1.7 & 2.0 & 1.4 & 1.6 & 1.1 & 1.6 & 1.2 & 1.3 \\
\hline United Kingdom & 2.3 & 1.9 & 2.2 & 2.1 & 1.9 & 1.3 & 1.8 & 1.6 \\
\hline Greece & 2.4 & 1.8 & 1.2 & 1.4 & 1.9 & 1.7 & 1.3 & 1.4 \\
\hline Hungary & 2.4 & 2.5 & 1.7 & 2.0 & 2.6 & 2.7 & 2.0 & 2.3 \\
\hline Ireland & 4.7 & 2.1 & 1.7 & 1.9 & 3.2 & 1.3 & 0.9 & 1.1 \\
\hline Iceland & 3.0 & 2.2 & 2.4 & 2.3 & 1.8 & 1.2 & 1.9 & 1.6 \\
\hline Israel & 3.7 & 2.7 & 2.6 & 2.6 & 1.5 & 1.3 & 1.6 & 1.5 \\
\hline Italy & 1.0 & 1.3 & 1.5 & 1.4 & 0.6 & 0.9 & 1.5 & 1.3 \\
\hline Japan & 0.9 & 1.2 & 1.4 & 1.3 & 0.8 & 1.4 & 1.9 & 1.7 \\
\hline Korea & 4.6 & 2.7 & 1.0 & 1.6 & 4.0 & 2.5 & 1.4 & 1.8 \\
\hline Luxembourg & 3.8 & 2.1 & 1.3 & 1.7 & 2.3 & 1.1 & 0.8 & 0.9 \\
\hline Mexico & 2.6 & 3.4 & 2.7 & 3.0 & 1.2 & 2.5 & 2.6 & 2.5 \\
\hline Netherlands & 2.2 & 1.8 & 1.6 & 1.7 & 1.7 & 1.5 & 1.7 & 1.6 \\
\hline Norway & 3.0 & 2.9 & 1.9 & 2.3 & 2.2 & 2.0 & 1.4 & 1.6 \\
\hline New Zealand & 2.7 & 2.7 & 2.6 & 2.6 & 1.6 & 1.8 & 2.2 & 2.0 \\
\hline Poland & 4.3 & 2.6 & 1.0 & 1.6 & 4.4 & 2.6 & 1.4 & 1.9 \\
\hline Portugal & 1.7 & 1.4 & 1.4 & 1.4 & 1.3 & 1.4 & 1.6 & 1.5 \\
\hline Slovak Republic & 4.5 & 2.9 & 1.4 & 2.0 & 4.4 & 2.8 & 1.7 & 2.1 \\
\hline Slovenia & 2.6 & 2.0 & 1.6 & 1.8 & 2.2 & 1.7 & 1.8 & 1.8 \\
\hline Sweden & 2.5 & 2.4 & 1.8 & 2.0 & 2.1 & 1.7 & 1.5 & 1.6 \\
\hline Turkey & 4.2 & 4.5 & 1.9 & 2.9 & 2.8 & 3.6 & 1.8 & 2.5 \\
\hline United States & 2.5 & 2.3 & 2.0 & 2.1 & 1.5 & 1.5 & 1.5 & 1.5 \\
\hline Argentina & 3.6 & 3.6 & 2.2 & 2.7 & 2.6 & 2.9 & 1.9 & 2.3 \\
\hline Brazil & 3.3 & 4.1 & 2.0 & 2.8 & 2.1 & 3.4 & 2.1 & 2.6 \\
\hline China & 10.0 & 6.6 & 2.3 & 4.0 & 9.3 & 6.4 & 2.8 & 4.2 \\
\hline Indonesia & 4.4 & 5.3 & 3.4 & 4.1 & 3.1 & 4.5 & 3.3 & 3.8 \\
\hline India & 7.5 & 6.7 & 4.0 & 5.1 & 5.8 & 5.6 & 3.6 & 4.4 \\
\hline Russia & 5.1 & 3.0 & 1.3 & 1.9 & 5.4 & 3.2 & 1.7 & 2.3 \\
\hline Saudi Arabia & 4.4 & 4.2 & 2.4 & 3.1 & 1.3 & 2.5 & 1.7 & 2.0 \\
\hline South Africa & 3.4 & 3.9 & 2.5 & 3.0 & 2.1 & 3.4 & 2.3 & 2.7 \\
\hline World unweighted average $^{2}$ & 3.1 & 2.8 & 1.9 & 2.2 & 2.3 & 2.3 & 1.8 & 2.0 \\
\hline World weighted average $^{2}$ & 3.5 & 3.7 & 2.3 & 2.9 & 2.5 & 3.1 & 2.3 & 2.6 \\
\hline OECD unweighted $^{2}$ & 2.8 & 2.3 & 1.7 & 2 & 2.1 & 1.8 & 1.7 & 1.7 \\
\hline Non-OECD unweighted ${ }^{2}$ & 4.3 & 4.7 & 2.5 & 3.3 & 3.1 & 4.0 & 2.4 & 3.0 \\
\hline OECD weighted ${ }^{2}$ & 2.2 & 2.2 & 1.8 & 2.0 & 1.5 & 1.7 & 1.7 & 1.7 \\
\hline Non-OECD weighted $^{2}$ & 6.7 & 5.9 & 2.8 & 3.9 & 5.6 & 5.2 & 2.7 & 3.7 \\
\hline
\end{tabular}

1. 1995 or first year available.

2. Aggregate calculations start in 1996. For a few countries where trend GDP is not available at the beginning of the sample period, actual GDP is used in place of trend GDP.

3. World GDP is the sum of GDP for 34 OECD and 8 non-OECD countries. 
Table A8.2. Trend GDP per capita in USD 2005 PPPs: selected years

\begin{tabular}{|c|c|c|c|c|}
\hline & \multicolumn{4}{|c|}{ GDP per capita USD 2005 PPPs } \\
\hline & & 2011 & 2030 & 2060 \\
\hline AUS & Australia & 36445 & 52635 & 87077 \\
\hline AUT & Austria & 36760 & 46305 & 69323 \\
\hline BEL & Belgium & 33457 & 44105 & 72355 \\
\hline CAN & Canada & 36249 & 46713 & 80674 \\
\hline CHE & Switzerland & 38064 & 50516 & 87509 \\
\hline CHL & Chile & 15024 & 28122 & 50980 \\
\hline CZE & Czech Republic & 24114 & 39206 & 68804 \\
\hline DEU & Germany & 34677 & 46023 & 72270 \\
\hline DNK & Denmark & 33583 & 40718 & 74003 \\
\hline ESP & Spain & 28774 & 39046 & 56962 \\
\hline EST & Estonia & 18336 & 32714 & 65512 \\
\hline FIN & Finland & 32473 & 45477 & 71895 \\
\hline FRA & France & 30764 & 41422 & 59157 \\
\hline GBR & United Kingdom & 33462 & 42467 & 72010 \\
\hline GRC & Greece & 24361 & 33522 & 48683 \\
\hline HUN & Hungary & 17799 & 29478 & 53232 \\
\hline IRL & Ireland & 39480 & 50316 & 66788 \\
\hline ISL & Iceland & 34930 & 43688 & 77356 \\
\hline ISR & Israel & 26818 & 34042 & 55294 \\
\hline ITA & Italy & 27914 & 33374 & 52097 \\
\hline JPN & Japan & 31640 & 41591 & 73619 \\
\hline KOR & Korea & 28343 & 45229 & 68957 \\
\hline LUX & Luxembourg & 71607 & 87453 & 112115 \\
\hline MEX & Mexico & 12964 & 20844 & 44466 \\
\hline NLD & Netherlands & 37748 & 50436 & 82817 \\
\hline NOR & Norway & 39160 & 57126 & 87074 \\
\hline NZL & New Zealand & 25681 & 35873 & 69368 \\
\hline POL & Poland & 17897 & 29395 & 45135 \\
\hline PRT & Portugal & 21962 & 28518 & 46040 \\
\hline SVK & Slovak Republic & 20681 & 34913 & 58047 \\
\hline SVN & Slovenia & 25389 & 35142 & 59560 \\
\hline SWE & Sweden & 35272 & 48926 & 76149 \\
\hline TUR & Turkey & 13484 & 26294 & 44773 \\
\hline USA & United States & 44256 & 58699 & 92197 \\
\hline ARG & Argentina & 14698 & 25155 & 43945 \\
\hline BRA & Brazil & 10311 & 19571 & 36518 \\
\hline CHN & China & 7358 & 23877 & 54651 \\
\hline IDN & Indonesia & 4051 & 9400 & 24781 \\
\hline IND & India & 3120 & 8730 & 25251 \\
\hline RUS & Russia & 15299 & 28015 & 46156 \\
\hline SAU & Saudi Arabia & 9958 & 15956 & 26732 \\
\hline \multirow[t]{2}{*}{ ZAF } & South Africa & 9894 & 18710 & 37226 \\
\hline & Unweighted average & 26292 & 37375 & 61847 \\
\hline Total & Weighted average & 13058 & 23452 & 46049 \\
\hline
\end{tabular}


ECO/WKP(2012)77

Table A8.3. Comparison of trend real GDP projections ${ }^{1}$

Average annual growth rates, \%

\begin{tabular}{|c|c|c|c|c|c|c|c|}
\hline & \multicolumn{2}{|c|}{ LT scenarios } & \multicolumn{2}{|c|}{ Duval and de la Maisonneuve (2010) } & \multicolumn{2}{|c|}{ Merola and Sutherland (2012) } & \multirow{2}{*}{$\begin{array}{c}\text { МТВ89 } \\
2011-2026\end{array}$} \\
\hline & $2011-2030$ & $2030-2050$ & $2011-2030$ & $2030-2050$ & $2011-2030$ & $2030-2050$ & \\
\hline Australia & 3.1 & 2.3 & 2.4 & 2.0 & 2.7 & 2.1 & 2.9 \\
\hline Austria & 1.5 & 1.4 & 1.9 & 1.4 & 1.8 & 1.2 & 1.6 \\
\hline Belgium & 2.1 & 2.0 & 2.3 & 1.8 & 1.9 & 1.6 & 1.4 \\
\hline Canada & 2.1 & 2.3 & 2.3 & 2.0 & 1.7 & 2.0 & 1.9 \\
\hline Chile & 4.0 & 2.3 & 3.6 & 3.0 & n.a & n.a & 3.4 \\
\hline Czech Republic & 2.7 & 1.8 & 2.2 & 1.5 & 2.2 & 1.1 & 2.4 \\
\hline Denmark & 1.3 & 2.1 & 1.5 & 1.5 & 1.3 & 1.6 & 1.2 \\
\hline Estonia & 2.8 & 2.1 & 3.4 & 1.7 & n.a & n.a & 2.4 \\
\hline Finland & 2.1 & 1.6 & 2.2 & 1.7 & 2.3 & 1.6 & 1.8 \\
\hline France & 2.0 & 1.4 & 2.5 & 2.0 & 1.6 & 1.6 & 1.6 \\
\hline Germany & 1.3 & 1.0 & 1.4 & 1.3 & 1.2 & 0.8 & 1.2 \\
\hline Greece & 1.8 & 1.1 & 2.4 & 1.6 & 2.0 & 0.9 & 1.6 \\
\hline Hungary & 2.5 & 1.8 & 2.8 & 1.8 & 1.9 & 0.9 & 1.4 \\
\hline Iceland & 2.2 & 2.4 & 2.2 & 1.8 & n.a & n.a & 2.2 \\
\hline Ireland & 2.1 & 1.7 & 3.5 & 2.4 & 2.9 & 1.8 & 2.9 \\
\hline Israel & 2.7 & 2.6 & 3.7 & 3.2 & n.a & n.a & 3.6 \\
\hline Italy & 1.3 & 1.6 & 2.1 & 1.5 & 1.5 & 0.8 & 1.1 \\
\hline Japan & 1.2 & 1.3 & 1.5 & 0.9 & 1.1 & 0.6 & 1.3 \\
\hline Korea & 2.7 & 1.0 & 2.8 & 1.0 & 2.0 & 0.3 & 2.7 \\
\hline Luxembourg & 2.1 & 1.4 & 3.2 & 2.7 & 2.8 & 2.4 & 2.8 \\
\hline Mexico & 3.4 & 3.0 & 3.8 & 2.9 & n.a & n.a & 3.0 \\
\hline Netherlands & 1.8 & 1.5 & 1.8 & 1.7 & 1.5 & 1.5 & 1.2 \\
\hline New Zealand & 2.7 & 2.7 & 2.7 & 2.4 & 2.3 & 2.0 & 2.4 \\
\hline Norway & 2.9 & 2.0 & 1.9 & 1.7 & n.a & n.a & 2.9 \\
\hline Poland & 2.6 & 1.0 & 3.0 & 1.5 & 1.5 & 0.6 & 2.0 \\
\hline Portugal & 1.4 & 1.5 & 2.3 & 1.8 & 1.4 & 0.7 & 2.1 \\
\hline Slovak Republic & 2.9 & 1.5 & 2.9 & 1.4 & 2.5 & 0.7 & 2.2 \\
\hline Slovenia & 2.0 & 1.7 & 1.8 & 1.2 & n.a & n.a & 1.2 \\
\hline Spain & 2.0 & 1.4 & 2.7 & 1.6 & 2.0 & 1.0 & 2.3 \\
\hline Sweden & 2.4 & 1.8 & 2.1 & 1.9 & 2.1 & 1.9 & 1.9 \\
\hline Switzerland & 2.2 & 2.1 & 1.7 & 1.6 & 1.7 & 1.7 & 1.9 \\
\hline Turkey & 4.5 & 2.3 & 5.7 & 3.9 & n.a & n.a & 3.4 \\
\hline United Kingdom & 1.9 & 2.2 & 2.1 & 1.9 & 2.1 & 1.9 & 1.9 \\
\hline United States & 2.3 & 2.1 & 2.5 & 2.1 & 2.3 & 2.1 & 2.3 \\
\hline Argentina & 3.6 & 2.3 & 3.2 & 3.2 & n.a & n.a & n.a \\
\hline Brazil & 4.1 & 2.5 & 4.0 & 3.6 & n.a & n.a & n.a \\
\hline China & 6.6 & 2.8 & 5.1 & 3.0 & n.a & n.a & n.a \\
\hline India & 6.7 & 4.5 & 6.8 & 5.3 & n.a & n.a & n.a \\
\hline Indonesia & 5.3 & 3.7 & 4.5 & 4.8 & n.a & n.a & n.a \\
\hline Russia & 3.0 & 0.9 & 2.7 & 2.0 & n.a & n.a & n.a \\
\hline Saudi Arabia & 4.2 & 2.7 & 5.2 & 4.3 & n.a & n.a & n.a \\
\hline South Africa & 3.9 & 2.7 & 3.7 & 3.4 & n.a & n.a & n.a \\
\hline Average (unweighted) & 2.8 & 2.0 & 2.9 & 2.2 & 1.9 & 1.4 & 2.1 \\
\hline Average excluding non-OECD & 2.3 & 1.8 & 2.6 & 1.9 & 1.9 & 1.4 & 2.1 \\
\hline
\end{tabular}

1. The assumptions underlying the projections differ, notably concerning structural policies. For instance, Duval and de la Maisonneuve (2010) assumes convergence in labour force participation towards best practices as well as assuming a higher global MFP growth rate than the one in this paper, which can partly explain their generally more optimistic growth scenario as compared with the projections in this paper. Merola and Sutherland (2012) only include fiscal consolidation in their baseline and no other structural reforms, in turn contributing to explaining their slightly lower numbers as compared with this study. Growth rates are calculated as cumulative growth rates except in the case of Merola and Sutherland (2012).

Sources: Duval and de La Maisonneuve (2010); Merola and Sutherland (2012); and the Medium-Term Baseline from OECD Economic Outlook No.89. "LT scenarios" denote projections from the current study. 


\section{APPENDIX 9. CONVERGENCE IN HOURS WORKED HAS LITTLE IMPACT ON PROJECTIONS}

85. Ideally, labour utilisation should be measured in terms of total hours worked rather than total employment. Compared to the baseline, accounting for hours worked in the production function could affect the relative importance of labour input versus MFP in the starting year since mis-measurement of the labour input would be reflected in the residual computation of MFP. The resulting bias in the initial gap between actual and steady state MFP would, in turn, affect projected MFP dynamics. However, available data on average hours worked are not always comparable across countries (OECD, 2008a). In addition, data are missing (or measured with great uncertainty) for some key emerging economies, notably India and China. In the context of cross-country convergence scenarios, it is obviously important that inputs are computed in similar ways in different countries.

86. Keeping in mind these data limitations, the role of hours for long-run growth scenarios was investigated. The historical decomposition of GDP per capita was adjusted to account for the average number of hours worked. The productivity dynamics are subsequently re-estimated, based on a productivity measure, that accounts for hours in order to re-assess the convergence path. In this sensitivity scenario, future hours worked are assumed to slowly converge to the average level (around 1670 hours per year) observed among a sub-set of OECD countries over the period 2000-2010.$^{39}$ Future paths for other GDP components remain as in the baseline. The resulting MFP path shows a convergence process that is initially (over the period 2011-2020) slightly faster than the baseline, whereas after 2030 it tends to be slower. Nonetheless, the average growth in MFP over the projection period remains broadly in line with the baseline. The relative contribution of different production factors to cross-country GDP per capita differences in 2060 and the ranking of GDP per capita in 2060 relative to the United are for most countries in line with the baseline. The correlation of the ranking of GDP per capita in 2060 between the baseline and including hours is around 0.95 .

39. The speed of convergence is about $3 \%$ per year (which roughly corresponds to observed convergence in hours during the last decades), implying that it takes approximately 23 years to close the initial gap in hours worked. Average levels of hours worked are based on the following countries: Australia, Belgium, Canada, Switzerland, Germany, Denmark, Finland, France, the United Kingdom, Ireland, Italy, Japan, Korea, Netherlands, Norway, New Zealand, Sweden and the United States. 
ECO/WKP(2012)77

\section{APPENDIX 10: TECHNICAL DESCRIPTION OF THE BASELINE LONG-TERM (BLT) MODEL}

\section{Overview of the model}

87. The BLT model is an annual model which can be used to extend the 2-21/2-year short-term projections which are regularly published in the OECD Economic Outlook to a horizon of about 50 years. Thus, the projections reported in this paper end in 2060. The model is a replacement for the OECD's Medium-Term Baseline (MTB) model (Beffy et al., 2006) which was also used to extend the OECD Economic Outlook projections, but over a shorter horizon (the MTB model was originally designed to consider macroeconomic trends to a point where the current business cycle is completed).

88. The countries covered by the model include all OECD countries as well as the non-OECD G20 countries (Argentina, Brazil, China, India, Indonesia, the Russian Federation, Saudi Arabia and South Africa). This covers about $90 \%$ of world nominal dollar GDP in 2010 at market exchange rates (using the IMF's World Economic Outlook September 2011 database to provide an estimate of world GDP). The level of detail in the model is greater for OECD countries than non-OECD countries, mostly reflecting the wider availability of a consistent data set for OECD countries, particularly in respect of fiscal accounts.

89. In addition, for the purposes of determining current account balances, a group of major nonOECD oil-exporting countries is also defined, which includes Saudi Arabia and Russia as well as 27 smaller non-OECD countries (Azerbaijan, Kazakhstan, Turkmenistan, Brunei, Bahrain, Iran, Iraq, Kuwait, Libya, Oman, Qatar, United Arab Emirates, Yemen, Ecuador, Trinidad and Tobago, Venezuela, Algeria, Angola, Chad, Republic of Congo, Equatorial Guinea, Gabon, Nigeria, Sudan). For this group of countries, no separate country-specific projections of current balances are made. Rather, the combined current account balance of all non-OECD oil exporting countries is projected based on third-party projections of their balance of trade in oil.

\section{Model focus}

90. The backbone for the model is provided by a consistent set of long-run projections of potential output. Around these growth projections, the focus of the model is on fiscal sustainability in OECD countries and trends in savings and investment, which are used to generate current account balances and hence provide projections of the scale of future global current account imbalances (measured here as the absolute sum of current account balances normalised on world GDP). Movements in global interest rates ensure that global saving and investment are aligned.

91. The remainder of this Appendix provides a more detailed description of the model's key equations on a sector-by-sector basis. It should, however, be borne in mind that as it currently stands, the model is relatively simple and could easily be developed in a number of directions as discussed in a final section.

\section{A sector-by-sector description of the model}

92. In what follows variable names mostly follow the OECD Secretariat's Analytical Database (ADB) variable conventions and are listed in Table A10.1 at the end of the appendix, with a suffix Q usually denoting the ratio of a variable to GDP or trend GDP. Where a relationship is specified entirely in contemporaneous terms, no time subscripts are shown, but where the relationship is not contemporaneous time subscripts are used. " $\Delta$ " denotes the first difference operator, " $\mathrm{g}(X)$ " denotes the growth rate of variable $X$, calculated as $100^{*}(X / X(-1)-1)$ and "In" denotes logarithm. 


\section{Growth, capital stock and investment}

93. Potential output is based on a Cobb-Douglas production function with constant returns to scale featuring physical capital, human capital and labour as production factors plus labour-augmenting technological progress (see Appendix 1 for details). Based on trend components of these inputs, a measure of potential output is derived over history, and by projecting these trend components while assuming a degree of convergence in total factor productivity, potential output can also be projected over a 50 -year period.

94. An initial projection of potential output, $Y B A S E$, is made assuming that the ratio of capital to potential output is stable, or if it has been recently trending, that this trend gradually flattens, consistent with a capital stock of KBASE. This is achieved by adopting an autoregressive rule whereby the annual change in the ratio of capital-to-potential-output is 0.85 times the change in the previous year (implying that after five years the rate of increase is about half the initial rate).

95. These initial underlying projections of potential output and capital stock are then subject to influences from variations in the cost of capital in a manner consistent with a Cobb-Douglas production function. This is achieved by calculating an equilibrium capital stock, $K S T A R$, which varies from $K B A S E$ according to the difference between the projected user cost of capital, $U C C$, and a notional user cost of capital, UCBASE. Both measures of the user cost of capital depend on the scrapping rate, RSCRP, and the real long-term interest rate, IRLR. However, $U C C$ allows for variations in the real interest rate due to changes in the fiscal risk premium and the 'global balancing premium' (both discussed below), whereas the notional concept $U C B A S E$ is calculated on the basis that both of these interest rate premia remain fixed at the values prevailing at the start of the projection. The actual capital stock, $K T P V$, adjusts gradually towards KSTAR according to a calibrated rule.

$$
\begin{aligned}
& \text { GDPVTR }=\text { YBASE } *\left[\frac{K T P V}{K B A S E}\right]^{(1-\tau)} \\
& K T P V_{t}=0.9 *\left[K B A S E_{t}+(1-R S C R P) *\left(K T P V_{t-1}-K B A S E_{t-1}\right)\right]+0.1 * K S T A R_{t} \\
& K S T A R=K B A S E *\left[\frac{G D P V T R}{Y B A S E}\right] *\left[\frac{(U C B A S E)}{(U C C)}\right] \\
& U C C=\text { const }+R S C R P+I R L R
\end{aligned}
$$

96. Actual real output $(G D P V)$ is assumed to converge to potential output from the last projected value available from the $O E C D$ Economic Outlook using a rule for the output gap (GAP) based on pooled estimation such that:

$$
\begin{aligned}
& \triangle G A P_{t}=0.2 * \Delta G A P_{t-1}-0.3 G A P_{t-1}, \\
& \text { where } G A P=(G D P V / G D P V T R-1) * 100,
\end{aligned}
$$

which in most cases implies that the output gap has closed or is very small within 4-5 years of the end of the OECD Economic Outlook projection horizon.

97. The projection of non-housing investment (ITV - IHV) is backed out from the capital stock:

$$
I T V_{t}-I H V_{t}=K T P V_{t}-(1-R S C R P) * K T P V_{t-1}
$$


where the rate of depreciation $R S C R P$ is assumed to stabilise over the projection at an average of pre-crisis observed values, or if historical values of the capital stock have been constructed by a perpetual inventory method, it is assumed to remain at $4 \%$. Housing investment moves gradually to a 10 -year average of its pre-crisis share of total investment, with some correction for countries that experienced a housing boom prior to the crisis.

\section{Saving}

98. For most OECD countries, private and public saving are separately distinguished, whereas for non-OECD countries, as well as Mexico, Turkey, Chile and Norway, only total national saving is projected given either the absence of detailed consistent data on fiscal accounts or the difficulty of using the OECD template for other reasons.

\section{OECD countries}

99. For OECD countries, private saving as a percentage of GDP $(S A V P G Q)$ is determined according to previous panel estimation work by the Secretariat (see Table 1 of Kerdrain et al., 2010), with effects from the old-age and youth dependency ratios (DROLD and DRYOUNG), the fiscal balance (NLGQ), the terms of trade (TTRADE), growth in productivity (PDTYPT), net oil trade balances as a share of GDP $(O I L B A L Q)$ and the availability of private credit as a share of GDP (PCRED). An explicit effect from the cycle is also included through an estimated output gap term $(G A P)$.

100. To counter concerns that using an old-age dependency ratio with fixed age limits may exaggerate demographic effects on saving over a long projection horizon given the tendency toward longer working lives, an additional effect from life expectancy (LIFEEXP) is included in the determination of savings for both OECD and non-OECD countries. This effect is based on the empirical findings of Li et al. (2007), and implies that a one year extension in life expectancy increases the aggregate saving rate by 0.2 percentage points.

$$
\begin{aligned}
\triangle S A V P G Q= & 0.542 * \mathrm{~g}(P D T Y P T)+0.172 * \mathrm{~g}(\text { TTRADE })-0.330 * \Delta D R O L D+ \\
& 0.432 * \Delta D R Y O U N G-0.400^{*} \Delta N L G Q-0.030 * \Delta P C R E D \\
& 0.030 * \Delta(\text { OILBALQ })-0.500 * \Delta G A P+0.200 * \Delta L I F E E X P
\end{aligned}
$$

Total national saving ( $S A V T G)$ is defined as the sum of public saving ( $S A V G G$ ) and private saving, although there is a $40 \%$ offset of any improvement in public saving from reduced private saving due to partial Ricardian equivalence, as represented by the coefficient on the fiscal balance term, $\triangle N L G Q$, in the above equation.

$$
S A V T G=S A V P G+S A V G G
$$

101. Various sources, or rules of thumb, are used to obtain projections of the exogenous variables that impact on saving. Demographic factors, such as dependency ratios and life expectancies, are based on United Nations and Eurostat projections. Private credit as a share of GDP is projected on the basis that countries gradually converge to the US level of financial development, with the gap assumed to close by $2 \%$ per annum. For example, this means that for an average of the BRIC countries, the availability of private credit rises from just over one-third of that in the United States in 2010 to around three-quarters in 2060. Net oil trade balances are based on the International Energy Agency's long-term projections (IEA, 2011). 


\section{Non-OECD countries}

102. For non-OECD countries, the total saving rate is also determined according to previous panel estimation work by the Secretariat, with effects from the old-age and youth dependency ratios, the terms of trade, the availability of credit, the share of public expenditure in GDP, YPGQA (a proxy for public social protection) and productivity growth (see Table 2 of Kerdrain et al., 2010). As for OECD private saving, life expectancy is included to account for longer working lives and an estimated output gap term is added to account for the economic cycle:

$$
\begin{aligned}
\triangle S A V T G Q= & 0.326 * \mathrm{~g}(P D T Y P T)+0.263 * \mathrm{~g}(\text { TTRADE })-0.500 * \Delta G A P \\
& -0.572 * \Delta D R O L D-0.281 * \Delta D R Y O U N G-1.889 * \triangle Y P G Q A \\
& +0.300^{*} \Delta O I L B A L Q-0.039^{*} \triangle P C R E D+0.200 * \Delta L I F E E X P
\end{aligned}
$$

\section{Current account balances}

103. The current account balance $(C B)$ is defined as the difference between total savings (SAVTG) and total investment and stockbuilding (ITISK):

$$
C B=S A V T G-I T I S K+C B R,
$$

$C B R$ is a statistical discrepancy due to saving and investment being sourced from the National Accounts while the current balance is sourced from the Balance of Payments accounts. This discrepancy is projected by assuming that it gradually declines as a share of GDP.

\section{Global current account balance}

104. The global sum of current account balances in US dollars as a share of world nominal dollar GDP, WLD.WCBQ, is kept stable through adjustments to a "global balancing premium", WLD.RWEQ, which feeds into the determination of interest rates in all countries. If the world current account surplus increases either relative to the previous year or relative to its level in the last year prior to the projection (denoted below as $W L D . W C B Q_{t=0}$ ), then this global balancing risk premium falls, lowering interest rates in all countries and boosting investment relative to savings. This acts to stabilise the global current account:

$$
\Delta W L D . R W E Q_{t}=-0.05 * \Delta W L D . W C B Q_{t}-0.10 *\left(W L D . W C B Q_{t-1}-W L D . W C B Q_{t=0}\right)
$$

\section{Oil exporters}

105. The aggregate current account balance of non-OECD oil exporting countries (defined as Saudi Arabia and Russia plus the 27 other small non-OECD oil exporting countries listed previously in section 1) expressed as a share of GDP is projected on the basis of an empirically estimated relationship driven by the oil trade balance as a share of GDP. Oil balance projections for this group of countries are from IEA (2011). The dynamic response of the equation implies that following a positive shock to the oil balance (for example from higher oil prices), a much larger share of any higher oil revenues will be saved in the short run than in the long run:

$$
\triangle C B G D P R=-0.0005+0.86^{*} \triangle O I L B A L Q-0.35^{*}\left(C B G D P R_{t-1}-0.28^{*} O I L B A L Q_{t-1}\right)
$$




\section{Fiscal accounts}

106. The cyclical component of the fiscal balance is measured according to the standard OECD methodology (Girouard and André, 2005) so that as the output gap closes the actual fiscal balance converges to the underlying fiscal balance. Otherwise underlying primary government expenditure and revenue are used to stabilise the government-debt-to-GDP ratio at levels depending on the particular scenario considered. In the baseline scenario this typically involves gradual consolidation just sufficient to stabilise the debt ratio, whereas for variant policy scenarios a specific debt ratio is targeted.

107. The implicit interest rate paid on gross outstanding government debt, RATE, is defined as the ratio of gross interest payments, GGINTP, to the gross debt stock, GGFL. This implicit rate adjusts gradually to a weighted average of the short-term interest rate, IRS, and the long-term interest rate, IRL, as new debt is issued or rolled over. The speed of this adjustment depends on the share of outstanding debt that is refinanced annually, RFSH, which reflects the initial maturity structure of debt -- the longer the maturity structure of debt, then the slower the adjustment:

$$
R A T E_{t}=\left(1-R_{F S H}\right) * \frac{G G I N T P_{t-1}}{G G F L_{t-2}}+\left(R F S H_{t}\right) *\left[0.25 * I R S_{t}+0.75 * I R L_{t}\right]
$$

The initial value for RFSH at the start of the projections is based on data from the Bank for International Settlements. This share is assumed to gradually evolve to a common share of $20 \%$ across countries, although the speed at which it evolves depends on the extent of debt turnover.

\section{Interest rates}

108. The short-term interest rate, IRS, varies with the state of the cycle. Once the output gap has closed, the short-term interest rate depends on the inflation target, INFTARG, a 10-year average growth rate of real potential output, $\mathrm{g}_{10}(G D P V T R)$, plus the "global balancing premium", WLD.RWEQ, described above:

$$
\Delta I R S_{t}=-0.2 *\left[I R S_{t-1}-\text { constant }-\mathrm{g}_{10}(G D P V T R)-I N F T A R G_{t}-W L D . R W E Q_{t-1}\right]+0.5^{*} \Delta G A P_{t}
$$

109. The long-term interest rates, IRL, taken to be the rate on 10 -year government bonds, is determined as a forward convolution of short-term interest rates over the next ten years, plus a fixed term premium (TERM) and a fiscal risk premium. The fiscal risk premium, represented by the term $\Phi(.$.$) in the$ equation below, is determined in relation to the ratio of gross government debt to GDP: for every percentage point that the debt ratio exceeds a threshold of $75 \%$, the fiscal risk premium increases by 2 basis points, with an additional increase of 2 basis points for every percentage point that the debt ratio exceeds $125 \%$.

$$
I R L_{t}=T E R M+\sum_{j=0}^{9} I R S_{t+j}+\Phi\left(G G F L Q_{t}>75 \%, 125 \%\right)
$$

The fiscal risk premium for Japan is assumed to be an exception to this rule because of the high proportion of government debt which is financed from domestic sources, so the fiscal risk premium is assumed to be one quarter that of other countries.

\section{Inflation}

110. Inflation, specified in terms of the GDP deflator $(P G D P)$, is determined from a Phillips curve, with forward- and backward-looking inflation terms, the output gap and non-energy commodity prices 
(WPHD). It includes a term specified as the deviation of the inflation rate from a country-specific target (INFTARG), which implies that once the output gap returns to zero and commodity price inflation is stable, then inflation eventually returns to the target. The effect of real oil prices, ROILP (here measured in local currency and relative to the GDP deflator), on inflation is country-specific.

$$
\begin{aligned}
\mathrm{g}\left(\text { PGDP }_{t}\right) & =0.2 * \mathrm{~g}\left(\text { PGDP }_{t-1}\right)+0.2 * \mathrm{~g}\left(\text { PGDP }_{t+1}\right)+(1-0.2-0.2) * I N F T A R G+0.2 G A P_{t} \\
& +\delta \mathrm{g}\left(\text { ROILP }_{t}\right)+0.23 \mathrm{~g}\left(W P H D_{t}\right)
\end{aligned}
$$

\section{Exchange rates}

111. Bilateral exchange rates between most OECD countries remain unchanged in real terms. This is achieved by changing the nominal exchange rate relative to the US dollar in line with inflation differentials, where inflation is measured by the GDP deflator.

112. For non-OECD countries, as well as for those OECD countries below a certain real per capita income threshold relative to the United States (taken to be $40 \%$, and so including Chile, Mexico and Turkey), the real dollar exchange rate appreciates in line with convergence in living standards with the US through the so-called Harrod-Balassa-Samuelson effect, based on the empirical work of Rogoff (1996).

113. Purchasing power parity (PPPs) exchange rates convert to a common currency and equalise the purchasing power of different currencies. For cross-country comparisons they are preferable because market exchange rates (MER) underestimate income levels in low-income countries. This is because nontradable goods tend to be less expensive in low-income than in high-income countries (i.e. the HarrodBalassa-Samuelson effect). As countries develop, differences between PPPs and market exchange rates tend to decrease as productivity improvements in the tradable-goods sector increase the relative value of non-tradables. Accordingly, the real exchange rate, defined as the ratio of the PPP exchange rate to the market exchange rate against the dollar, $E X C H$, should appreciate over time in low-income countries. To implement this in the model, it is assumed that PPPs evolve in line with price inflation relative to US price inflation, and that the market exchange rate against the dollar converges on a path which deviates from PPP according to the difference in per capita incomes with the United States measured at 2005 PPPs, RLYPC.

$$
\begin{aligned}
& \Delta \ln P P P_{t}= \Delta \ln P G D P_{t}-\Delta \ln U S A . P G D P_{t} \\
& \begin{aligned}
\Delta \ln E X C H_{t}= & \Delta \ln U S A . P G D P_{t}-\triangle \ln P G D P_{t}+0.30^{*} \Delta \ln R L Y P C_{t} \\
& \quad-0.05^{*}\left[\ln E X C H_{t-1}+\ln P P P_{t-1}-0.30^{*} \ln R L Y P C_{t-1}\right]
\end{aligned}
\end{aligned}
$$

114. The resulting path for the deviation between market and PPP exchange rates is illustrated for a selection of non-OECD countries in Figure A10.1. The Harrod-Balassa-Samuelson effect is represented by movements along or parallel to the diagonal line in Figure A10.1, which shows the equilibrium gap between the real exchange rate and the PPP rate at each level of relative income per capita (in logs). Using only this adjustment and ignoring any initial disequilibrium between the real exchange rate and PPP -- represented by the vertical distance to the diagonal line in the figure at the start of convergence -- would maintain initial misalignments indefinitely and a currency could potentially permanently overshoot its PPP. Thus, long-term projections for real exchange rates also incorporate an adjustment toward the 'correct' deviation from PPP for a given relative income level based on estimated results, whereby 5\% of the remaining disequilibrium is corrected every year, consistent with Wilson et al. (2011) and Frankel (2006). The effect is represented by the gradual closing of the vertical distance between the starting point and the diagonal line in the figure. In the cases of Brazil and Indonesia, the estimated initial overvaluation of the 
real exchange rate relative to the Harrod-Balassa-Samuelson line pulls the real exchange rate down during the projection period, while the reverse is true of Argentina. Both China and India start the convergence process close to their equilibrium PPPs and therefore most of their projected real exchange rate appreciation is driven by relative income convergence.

Figure A10.1. Projections of Market exchange rates relative to PPP from 2013 to 2060, selected countries

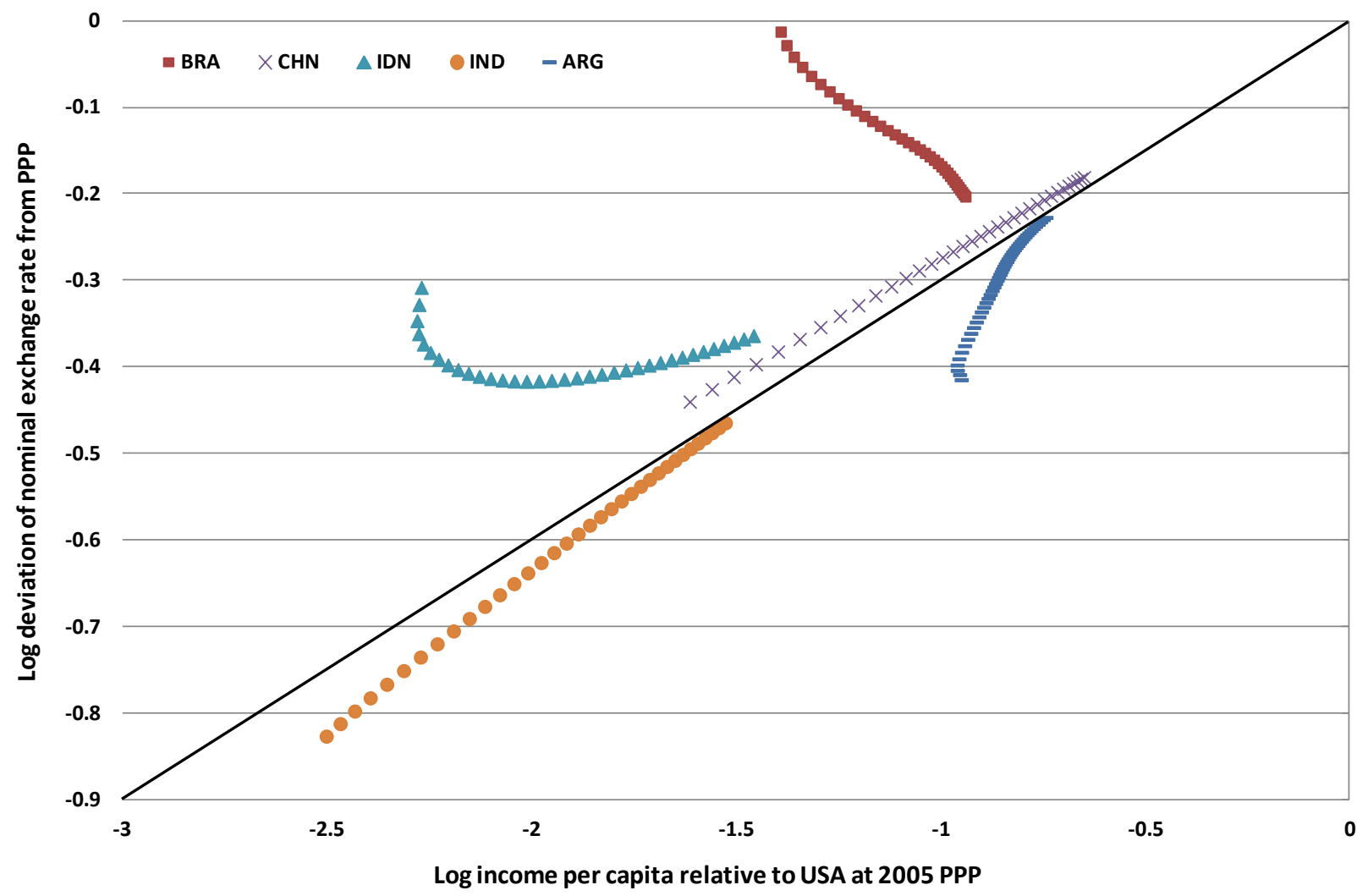

\section{Country-specific model notes}

115. All 34 OECD countries are represented in the model, along with 8 non-OECD countries that are members of the G20, and a grouping of oil exporters. However, data limitations prevent a full implementation of the same template for all countries. The main exceptions are noted in Table A10.1.

\section{Table A10.1. Divergences from the common template}

\begin{tabular}{l|l}
\hline \multicolumn{1}{c}{ Country } & Description \\
\hline Czech Republic & The long-term interest rate $(I R L)$ is built from the term structure of short-term rates $(I R S)$. \\
\hline Norway & The non-oil sector of the economy (mainland) is used for convergence and potential output. \\
\hline Chile, Turkey & Government finances are not represented due to data availability. \\
\hline Israel, Luxembourg & The refinancing share $(R F S H)$ is assumed constant over history due to data availability. \\
\hline $\begin{array}{l}\text { Argentina, China, } \\
\text { Indonesia, India, } \\
\text { Russia, South Africa }\end{array}$ & Government finances and interest rates are not modelled due to data availability. \\
\hline
\end{tabular}




\begin{tabular}{l|l}
\hline Estonia, Slovenia & $\begin{array}{l}\text { Long-term interest rates }(I R L) \text { are built from a term structure of short-term rates }(I R S) . \text { The } \\
\text { refinancing share }(R F S H) \text { is assumed constant over history due to data availability. }\end{array}$ \\
\hline Saudi Arabia & $\begin{array}{l}\text { The non-oil sector of the economy (mainland) is used for convergence and potential output. } \\
\text { Included in oil exporters to determined global saving; therefore, not explicitly modelled as } \\
\text { are other non-OECD. }\end{array}$ \\
\hline Oil Exporters & $\begin{array}{l}\text { Current balance is determined by projections of net oil exports, providing a supply of global } \\
\text { savings. }\end{array}$ \\
\hline
\end{tabular}

\section{Future model developments}

116. The BLT model is in an early stage of development and could be expanded in many directions, some of which are mentioned briefly below.

1. More country-specific estimation for key relationships. Many of the equations are based on panel regression estimates or stylised equations and more country-specific estimation would improve the fit of the equations and perhaps significantly change the model properties. An important example is the saving relationships for India and China, which are important because these two countries account for a large proportion of global saving and so have a significant effect on global interest rates. At present, the model equations determining saving in China and India are based on panel regressions, but these do not explain very well the increase in saving rates over the last decade or so in these countries.

2. Modelling the fiscal pressures from ageing. The model does not explicitly model the pressures from demographic changes on public expenditures such as on health or pensions. Explicit modelling of such effects could identify how much pressure is being placed on other components of public expenditure in fiscal consolidation scenarios.

3. More detailed modelling of oil. Further consideration could be given to modelling the effect of changes in oil prices and oil production. For oil-importing countries, higher oil prices should have an impact on saving via changes in the terms of trade. Large changes in oil prices might also have significant impacts on potential output as well as the long-run demand and supply of oil. For those OECD countries which are major oil producers, most notably Norway, the impact of changes in oil production and prices on fiscal accounts could be identified.

4. Providing an endogenous correction to persistent current account imbalances. At present there is nothing in the model specification to prevent a country from running a large persistent current account deficit or surplus. Accounting for net external debt positions and providing some feedback to either interest rate premia or saving could provide some endogenous correction to such tendencies. Alternatively, there are other ways of modelling the balance between saving and investment which might be less prone to generate persistent account imbalances. For example, Fouré et al. (2012) estimate an error-correction Feldstein-Horioka-type relationship between savings and investment rates as the basis for model projections.

5. Further enriching the convergence framework. At present, the main impact of policies on total factor productivity is through changes in product market regulation, but it might be possible to identify further empirical links between policy and the convergence process. 
ECO/WKP(2012)77

Table A10.2. Variable list

\begin{tabular}{|c|c|}
\hline Variable name & Description \\
\hline CAPOG & Net capital outlays of the government, value \\
\hline $\mathrm{CB}$ & Current account balance, value \\
\hline CBD & Current account balance, value in USD \\
\hline CBGDPR & Current account balance, as a percentage of GDP \\
\hline CFKG & Government consumption of fixed capital, value \\
\hline COEFTERM & Target term premium on long-term rates \\
\hline DROLD & Dependency ratio for individuals 65 + relative to the population 15 to 64 \\
\hline DRYOUNG & Dependency ratio for individuals 0 to 14 relative to the population 15 to 64 . \\
\hline ETPT & Potential employment of the total economy \\
\hline $\mathrm{EXCH}$ & Exchange rate, USD per National currency \\
\hline GAP & Output gap of the total economy \\
\hline GDP & Gross domestic product, value, market prices \\
\hline GDPD & Gross domestic product, value, at 2005 PPP, USD \\
\hline GDPPOP & Gross domestic product per capita, volume, at 2005 PPP, USD \\
\hline GDPTR & Potential output of total economy, value \\
\hline GDPV & Gross domestic product, volume, market prices \\
\hline GDPVD & Gross domestic product, volume, at 2005 PPP, USD \\
\hline GDPVTR & Potential output of total economy, volume \\
\hline GFAR & General government gross financial assets, as a percentage of GDP \\
\hline GGFL & General government gross financial liabilities, value \\
\hline GGFLQ & General government gross financial liabilities, as a percentage of GDP \\
\hline GGINTP & Gross government interest payments, value \\
\hline GGINTPQ & Gross government interest payments, as a percentage of GDP \\
\hline GGINTR & Gross government interest receipts, value \\
\hline GGINTRQ & Gross government interest receipts, as a percentage of GDP \\
\hline GNFL & General government net financial liabilities, value \\
\hline GNFLQ & General government net financial liabilities, as a percentage of GDP \\
\hline HSHARE & Housing share of total investment \\
\hline $\mathrm{IHV}$ & Gross fixed capital formation, housing, volume \\
\hline INFTARG & Inflation target \\
\hline $\mathrm{IRL}$ & Long-term interest rate on government bonds \\
\hline IRLR & Real long-term interest rate on government bonds \\
\hline IRS & Short-term interest rate \\
\hline IRSNEUT & Country-specific neutral short-term interest rate \\
\hline ISK & Stockbuilding, value \\
\hline IT & Gross fixed capital formation, total, value \\
\hline ITISK & Gross capital formation, value \\
\hline ITV & Gross fixed capital formation, total, volume \\
\hline KBASE & Baseline productive capital stock of the private sector, volume \\
\hline KSTAR & Target productive capital stock of the private sector, volume \\
\hline KTPV & Productive capital stock of the private sector, volume \\
\hline LIFEXP & Life expectancy \\
\hline NLG & Government net lending, value \\
\hline NLGA & Cyclically adjusted government net lending, value \\
\hline NLGQ & Government net lending, as a percentage of GDP \\
\hline NLGQA & Cyclically adjusted government net lending, as a percentage of potential GDP \\
\hline
\end{tabular}


ECO/WKP(2012)77

\begin{tabular}{|c|c|}
\hline NLGU & Underlying government net lending, value \\
\hline NLGX & Government primary balance, value \\
\hline NLGXA & Cyclically adjusted government primary balance, value \\
\hline NLGXQU & Underlying government primary balance, as a percentage of potential GDP \\
\hline NLGXU & Underlying government primary balance, value \\
\hline OILBALQ & Oil trade balance, as percentage of GDP \\
\hline OILNETEXPB & Oil exports, net volume \\
\hline PCRED & Credit to the private sector, share of GDPTR \\
\hline PDTYPT & Labour productivity of the total economy \\
\hline PGDP & Gross domestic product, deflator, market prices \\
\hline PIT & Gross total fixed capital formation, deflator \\
\hline PPP & Purchasing power parity, National currency per USD \\
\hline RATE & Implicit interest rate on gross government debt outstanding \\
\hline $\mathrm{REXCH}$ & Real exchange rate \\
\hline RFSH & Share of gross government debt outstanding to be refinanced within one year \\
\hline RFSHTARG & Assumed long-run target for RFSH \\
\hline RLYPC & Real per capita income relative to the USA, at 2005 PPP \\
\hline RSCRP & Total economy scrapping rate of productive capital \\
\hline RWEQ & Global interest-rate balancing premium (on national long-term interest rates) \\
\hline SAVGG & Gross government saving, value \\
\hline SAVGGQ & Gross government saving, as a percentage of GDP \\
\hline SAVPGQ & Gross private saving, as a percentage of GDP \\
\hline SAVTG & Gross total saving, value \\
\hline SAVTGQ & Gross total saving, as a percentage of GDP \\
\hline SDGNFL & Statistical discrepancy of government net financial liabilities \\
\hline TERMPREM & Term premium on long-term interest rates \\
\hline TTRADE & Terms of trade, goods and services \\
\hline UCC & User cost of capital \\
\hline UCBASE & User cost of capital, assuming no change in fiscal or global balancing interest rate premia. \\
\hline WCBQ & World current account balance as a share of global GDP \\
\hline WPBRENT & Brent crude oil, world price \\
\hline WPHD & Primary commodities excl. energy, world price \\
\hline YBASE & Baseline potential output, volume \\
\hline YPGA & Cyclically adjusted current disbursements, general government, value \\
\hline YPGXA & Cyclically adjusted current disbursements excluding interest, general government, value \\
\hline YRGA & Cyclically adjusted current receipts, general government, value \\
\hline YRGXA & Current receipts excluding gross interest receipts, general government, value \\
\hline
\end{tabular}




\section{WORKING PAPERS}

The full series of Economics Department Working Papers can be consulted at www.oecd.org/eco/workingpapers/

999. Selected aspects of household savings in Germany - evidence from micro-data

(November 2012) by Christina Kolerus, Isabell Koske and Felix Hüfner

998. Improving the tax system in Indonesia

(November 2012) by Jens Arnold

997. Unleashing business innovation in Canada

(November 2012) by Alexandra Bibbee

996. Public policy and resource allocation: evidence from firms in OECD countries

(October 2012) by Dan Andrews and Federico Cingano

995. Promoting SME development in Indonesia

(October 2012) by Annabelle Mourougane

994. Portugal: Rebalancing the economy and returning to growth through job creation and better capital allocation.

(October 2012) by Álvaro Pina and Ildeberta Abreu

993. Public debt, economic growth and nonlinear effects: Myth or reality?

(October 2012) by Balázs Égert

992. Choosing the pace of fiscal consolidation

(September 2012) by Lukasz Rawdanowicz

991. Tertiary education developing skills for innovation and long-term growth in Canada

(September 2012) by Calista Cheung, Yvan Guillemette and Shahrzad Mobasher-Fard

990. Trade and product market policies in upstream sectors and productivity in downstream sectors:

firm-level evidence from China

(September 2012) by Maria Bas and Orsetta Causa

989. Intangible assets, resource allocation and growth: a framework for analysis

(September 2012) by Dan Andrews and Alain de Serres

988. Current account benchmarks for Turkey

(September 2012) by Oliver Röhn

987. Structural reforms to boost Turkey's long-term growth

(September 2012) by Rauf Gönenç, Oliver Röhn, Vincent Koen and Şeref Saygili

986. Tackling Turkey's external and domestic macroeconomic imbalances

(September 2012) by Oliver Röhn, Rauf Gönenç, Vincent Koen and Ramazan Karaşahin

985. Portugal: Solid foundations for a sustainable fiscal consolidation

(September 2012) by David Haugh and Stéphane Sorbe 
984. Portugal: Assessing the risks around the speed of fiscal consolidation in an uncertain environment

(September 2012) by Stéphane Sorbe

983. The German labour market: preparing for the future (September 2012) by Felix Hüfner and Caroline Klein

982. Climate change policies in Germany: make ambition pay

(September 2012) by Caroline Klein

981. Restarting the growth engine in Finland

(September 2012) by Henrik Braconier

980. Import Competition, Domestic Regulation and Firm-Level Productivity Growth in the OECD (September 2012) by Sarra Ben Yahmed and Sean Dougherty

979. Non-Parametric Stochastic Simulations to Investigate Uncertainty around the OECD Indicator Model Forecasts

(August 2012) by Elena Rusticelli

978. Measuring GDP Forecast Uncertainty using Quantile Regressions

(July 2012) by Thomas Laurent and Tomasz Kozluk

977. Implications of output gap uncertainty in times of crisis

(July 2012) by Romain Bouis, Boris Cournède and Ane Kathrine Christensen

976. Avoiding debt traps: financial backstops and structural reforms

(July 2012) by Pier Carlo Padoan, Urban Sila and Paul van den Noord

975. Sluggish productivity growth in Denmark: the usual suspects?

(July 2012) by Müge Adalet McGowan and Stéphanie Jamet

974. Towards green growth in Denmark: improving energy and climate change policies (July 2012) by Stéphanie Jamet

973. An Analysis of Productivity Performance in Spain before and during the Crisis: Exploring the Role of Institutions

(June 2012) Juan S. Mora-Sanguinetti and Andrés Fuentes

972. Europe's new fiscal rules

(June 2012) by Sebastian Barnes, David Davidsson and Łukasz Rawdanowicz

971. Credit Crises and the Shortcomings of Traditional Policy Responses

(June 2012) by William R. White

970. International Capital Mobility and Financial Fragility

Part 7. Enhancing Financial Stability: Country-specific Evidence on Financial Account and Structural Policy Positions

(June 2012) by Rudiger Ahrend and Carla Valdivia 